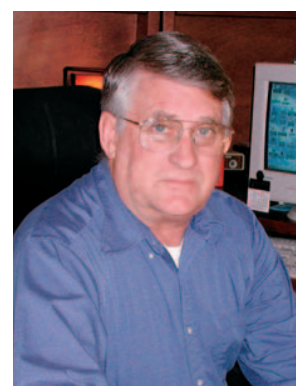

By Gary Frasier

\section{Frasier's Philosophy}

Conflict. The news media is full of conflict around the world on any topic you wish to pick. To many people, conflict is a violent confrontation. This type of conflict is happening in the Middle East or in some countries in Africa.

There are many other instances where conflict is nothing more than a difference of opinion or a viewpoint. These conflicts can be very emotional and important to the individuals involved. This is the type of conflict that occurs when discussing wildlife habitat. Although some people will not admit it, there are two sides to the question. It is the responsibility of the resource manager to find the solution that will allow a sustainability of the resource and still allow the various users of the land to meet their objectives. This is not an easy task. In many instances it is necessary for some "give and take" on all sides.

In this issue of Rangelands, with the theme of wildlife, we discuss one of these conflicts, concerning sage-grouse. With open-minded discussions, we can find where information is lacking. With adequate information, we can make an informed assessment of the problem and reach an agreement on how to manage the resource. As we assess the information, we must realize that our background, interests, and biases will affect how we interpret the information (is the glass half full or half empty?).

There are other instances of wildlife management that are just as contentious-black-tailed prairie dogs, spotted owls, and wolves, just to name a few. If we only look at one side of the problem, we will lose. The courts will decide what is to be done. As resource managers, we will have lost. I know that I do not agree with some people on how we should manage our wildlife habitat resources. I, at the same time, recognize that their side is just as valid to them as what I see on my side. I, as someone interested in proper resource management, have a responsibility to find a common ground that will allow everyone to meet their objectives. To meet a common resource management objective, I know that I will have to give up something and believe that the other side will also make some adjustments in their beliefs. This is the way to solve a conflict without it becoming so violent that only a court can resolve the issue. 


\title{
Society for Range Management Issue Paper: Ecology and Management of Sage-Grouse and Sage-Grouse Habitat-A Reply
}

\author{
By Michael A. Schroeder, John W. Connelly, Carl L. Wambolt, Clait E. Braun, \\ Christian A. Hagen, and Michael R. Frisina
}

\section{Introduction}

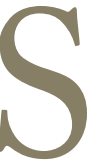
age-grouse (Centrocercus spp.) depend entirely on sagebrush (Artemisia spp.) ecosystems that dominate much of western North America. Historically, sagegrouse occurred in at least 12 western states and 3 Canadian provinces but have declined throughout much of their former range and have been extirpated from Nebraska and British Columbia. ${ }^{1}$ Concerns for long-term conservation of the species and potential threats to sage-grouse and the sagebrush habitats upon which they depend ${ }^{2}$ have resulted in at least 9 petitions requesting the US Fish and Wildlife Service list greater sage-grouse (Centrocercus urophasianus) and Gunnison sage-grouse (Centrocercus minimus) under the Endangered Species Act.

The Society for Range Management (SRM) recently developed an issue paper on sage-grouse and their habitats. ${ }^{3}$ We applaud the Society's recognition of these species and their habitats, as well as SRM's efforts to stress the importance of improved management of western rangelands to aid in the conservation of sage-grouse. However, we are concerned the issue paper presents information in an ambiguous fashion that is open to numerous interpretations. Moreover, the issue paper identifies potential constraints on sagegrouse populations or habitats for which there is little or no empirical evidence while ignoring other well-documented factors affecting the species and its habitat. Here, we provide a critique of that issue paper and attempt to correct any erroneous beliefs that may have been fostered by the information it presents.

\section{Background}

In 2005, SRM distributed a stand-alone publication, titled "Ecology and Management of Sage-Grouse and Sage-

This article has been peer reviewed.
Grouse Habitat" (both greater and Gunnison sage-grouse), with the December issue of Rangelands. ${ }^{3}$ Although there were no specific authors listed for the publication, it was subtitled "An Issue Paper Created by the Society for Range Management."

$\mathrm{SRM}^{3}$ stated (p. 7) that the publication was "based on an invited synthesis paper by Crawford et al," ${ }^{4}$ a published compilation of the symposium on sage-grouse presented at the annual SRM meeting in 2001. Crawford et $\mathrm{al}^{4}$ stated, "this paper synthesizes current knowledge regarding pertinent topics in sage-grouse ecology and management and suggests direction for future research and management" (p. 3). The only other published reference listed by $\mathrm{SRM}^{3}$ is a publication dealing with the distribution of sage-grouse. ${ }^{1}$

We are concerned about the length of time between the original symposium in February 2001 and the $\mathrm{SRM}^{3}$ distribution in December 2005. "Current knowledge," as referenced in Crawford et $\mathrm{al}^{4}$ (p. 3), tends to be a moving target. This is a pertinent consideration for sage-grouse because of the vibrancy of ongoing research efforts on sage-grouse throughout the West. A great deal of research has been conducted on sage-grouse in the time since the original synthesis $^{4}$ was published and in the 5 years since the SRM conference was held, upon which it was based. In addition, Crawford et $\mathrm{al}^{4}$ stated: "Our effort is not comprehensive to all factors affecting sage-grouse but is meant to provide expanded coverage of topical management concerns with an emphasis on habitat ecology" (p. 3). For instance, energy development and anthropogenic changes to the landscape were not addressed by the synthesis, but both have been identified as threats to conservation of sage-grouse. ${ }^{5}$ Thus, we question the utility of publishing a synthesis ${ }^{3}$ of a synthesis. ${ }^{4}$ By only focusing on 1 paper, the author or authors may provide an inaccurate and/or incomplete assessment of sagegrouse populations and habitat. 


\section{Sage-Grouse Distribution}

The descriptions of sage-grouse distribution, habitat relationships, and population ecology within the issue paper ${ }^{3}$ are general by design and, for the most part, correct. However, in the description of sage-grouse distribution $\mathrm{SRM}^{3}$ stated that "if sage-grouse were ever present in [Kansas and Oklahoma], they probably would have been Gunnison sagegrouse" (p. 1). Although the range map is from Schroeder et $\mathrm{al},{ }^{1}$ the correct reference to this statement is Young et al. ${ }^{6}$ In fact, Schroeder et $\mathrm{al}^{1}$ stated that because of contradictions in observations of behavior and habitat, they "did not attempt to define a presettlement distribution for potential sagegrouse habitat in regions dominated by sand sagebrush" (Artemisia filifolia; ie, Kansas and Oklahoma) (p. 371).

The issue paper ${ }^{3}$ also stated that much of the decline of sage-grouse populations was due to direct conversion of 11.1 million acres of sagebrush habitat to other habitats, such as cities and cropland. Most of this land, and especially that associated with urban expansion, was converted in the late 1800 s and early 1900s. Although we do not disagree with this general assertion, substantial evidence ${ }^{5}$ indicates many of the current problems are associated with habitat degradation and fragmentation. Declines in habitat quality provide the most defendable explanations for sage-grouse population declines occurring during the past 50 years. For instance, sage-grouse populations in North Dakota declined at an annual rate of $2.8 \%$ from 1965 to 2003 , long after cities and most farms in that state were established. ${ }^{5}$

\section{Habitat Relationships}

In the description of winter habitat, $\mathrm{SRM}^{3}$ stated that "severe winter conditions have little effect on sage-grouse populations unless snow completely covers sagebrush, and winter habitat does not usually limit sage-grouse populations" (p. 2). This statement is almost identical to one in Crawford et al, ${ }^{4}$ except that instead of stating that winter habitat is usually not limiting, Crawford et al stated that "adequate cover is typically available on a landscape scale . . . unless snow completely covers sagebrush" (p. 5). The difference in these statements is not trivial. If winter habitat does not limit sage-grouse populations, then grazing, herbicides, and mechanical treatments could be used to treat habitat by purposely reducing sagebrush canopy cover with little concern for affecting sagegrouse winter habitat. However, care needs to be taken with this statement because there is little evidence to support the observation that sagebrush is not limiting (Fig. 1). This is a particularly difficult problem to address because sagebrush can be extremely important during the nesting season (cover for nests) as well as during winter (primary source of food and protective cover). There are annual, habitat, regional, and landscape considerations to this issue. For example, research in Colorado ${ }^{7}$ showed that sagebrush cover was limited during a winter of above-average precipitation. It may be impossible in winters with average or below-average snow conditions to know exactly which areas of sagebrush are critical.

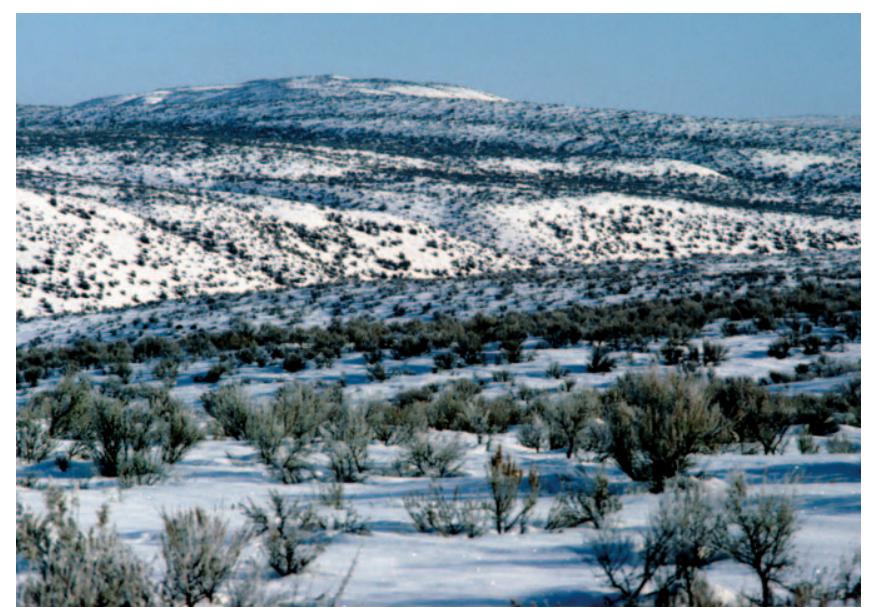

Figure 1. Big sagebrush is rarely distributed evenly across the landscape, as this wintering area in north-central Washington illustrates. Because sage-grouse depend on sagebrush for both food and cover, climatic conditions, such as the depth and distribution of snow, can influence which areas of a landscape are used by sage-grouse.

$\mathrm{SRM}^{3}$ also stated: "sagebrush canopy cover should not exceed $15 \%$ on lower-elevation sites or $25 \%$ on mountainous sites" (p. 5). This declaration of maximum or threshold values for sagebrush is not supported in Crawford et $\mathrm{al}^{4}$ nor in the numerous studies described in detail in Connelly et al. ${ }^{8}$ In fact, the range of average sagebrush cover values provided in previously published literature is 15\%-38\% around nest sites and $12 \%-43 \%$ at winter sites (usually above the snowpack). The difference between the maximum cover values provided in $\mathrm{SRM}^{3}$ and the averages provided by Crawford et $\mathrm{al}^{4}$ is substantial. Compounding the danger inherent in the SRM statement is the fact that sagebrush-cover determination by agencies for management objectives, based on previous research, is often unreliable (Fig. 2). ${ }^{9}$

The issue paper's ${ }^{3}$ section on nesting habitat describes sage-grouse nests as "generally located within 2 miles of a lek, but in some areas hens may nest much farther from leks" (p. 3). Based on other research, ${ }^{10}$ Crawford et $\mathrm{al}^{4}$ stated that " $55 \%$ of nests were within $3 \mathrm{~km}$ of the lek" (p. 6). The significance of these respective statements is that by using a predefined distance, such as 2 miles, ${ }^{11}$ the management of habitats may be easier, but a substantial portion of the breeding population may not be considered. For example, recent research in Wyoming showed that 36\% of nests were > 3 miles from a lek, ${ }^{12}$ and work in Idaho demonstrated that nests were randomly located relative to lek locations. ${ }^{10}$ Hence, protection of nesting habitat cannot be achieved by considering only the habitat within an arbitrary distance of known lek locations.

\section{Habitat Management Practices}

$\mathrm{SRM}^{3}$ stated: "Prescribed burning, as well as prescribed livestock grazing, herbicides, and mechanical treatments, can be used to enhance sage-grouse habitat by purposely reducing sagebrush canopy cover where dense sagebrush canopy cover 
limits understory forbs and grasses. However, sagebrush thinning should be avoided where sage-grouse winter habitat is limited ..." (p. 4).

The previous statement in the section on "Habitat Relationships," that "winter habitat does not usually limit sage-grouse populations," suggests this would rarely be an issue. The basic problem with these recommended practices for reducing sagebrush canopy cover is that there appears to be no peer-reviewed research showing that burning, spraying, or mechanically removing sagebrush has substantial positive impacts on sage-grouse. However, there are many papers indicating that sagebrush removal can adversely impact sagegrouse (eg, Connelly et $\mathrm{a}^{8,13}$ and Klebenow ${ }^{14}$ ). Wambolt et $\mathrm{al}^{2}$ concluded that fires typically destroy the more important portions of sage-grouse habitat, specifically by removing the larger and more productive sagebrush plants that provide cover and food, including important insect populations vital to sage-grouse diets. Prescribed fires, in fact, usually target habitats with the highest amounts of sagebrush cover, thereby often maximizing detrimental effects to sagebrush-dependant species like sage-grouse. Additionally, $\mathrm{SRM}^{3}$ earlier made the statement that "few research studies have examined the effects of these practices on sage-grouse populations and habitat use patterns" (p. 4). That statement is scientifically inconsistent with a recommendation for management action.

Encroachment by conifers is a significant issue in limited portions of the sage-grouse range. In addition, the rangewide conservation assessment of greater sage-grouse ${ }^{5}$ showed that the increase of wildfires has been dramatic across the range, but particularly in areas where conifer encroachment is not an issue. Consequently, vast portions of the range have been, and are being, influenced by fire without the need for prescribed burning. Moreover, Crawford et $\mathrm{al}^{4}$ stated: "In Wyoming big sagebrush-dominated communities, there is little evidence that fire will enhance sage-grouse habitat where there is already a balance of native shrubs, perennial grasses, and forbs" (p. 10). By recommending the consideration of prescribed fire, herbicides, and/or mechanical treatment, SRM appears to be pushing for a reduction of sagebrush cover when the potential for this cover to become a limiting factor is increasing. It is also possible that the fire return intervals given in the issue paper ${ }^{3}$ are incorrect. ${ }^{15}$

Livestock grazing tends to be controversial, and the paragraph referring to grazing in the issue paper $^{3}$ does little to alleviate the controversy. The statement ${ }^{3}$ that "light-to-moderate grazing in sagebrush rangeland is ecologically sustainable and can benefit sage-grouse" (p. 4) is not only a broad generalization for sage-grouse but also for the relationship between livestock and western rangelands. Light-to-moderate grazing may be sustainable but can be influenced by many factors, including weather, soil, habitat type, the species being grazed, and the timing of use, just to name a few. This is particularly true in sagebrush-dominated habitats where livestock management must be well managed to be sustainable, ${ }^{16}$ and even then, there are differing opinions
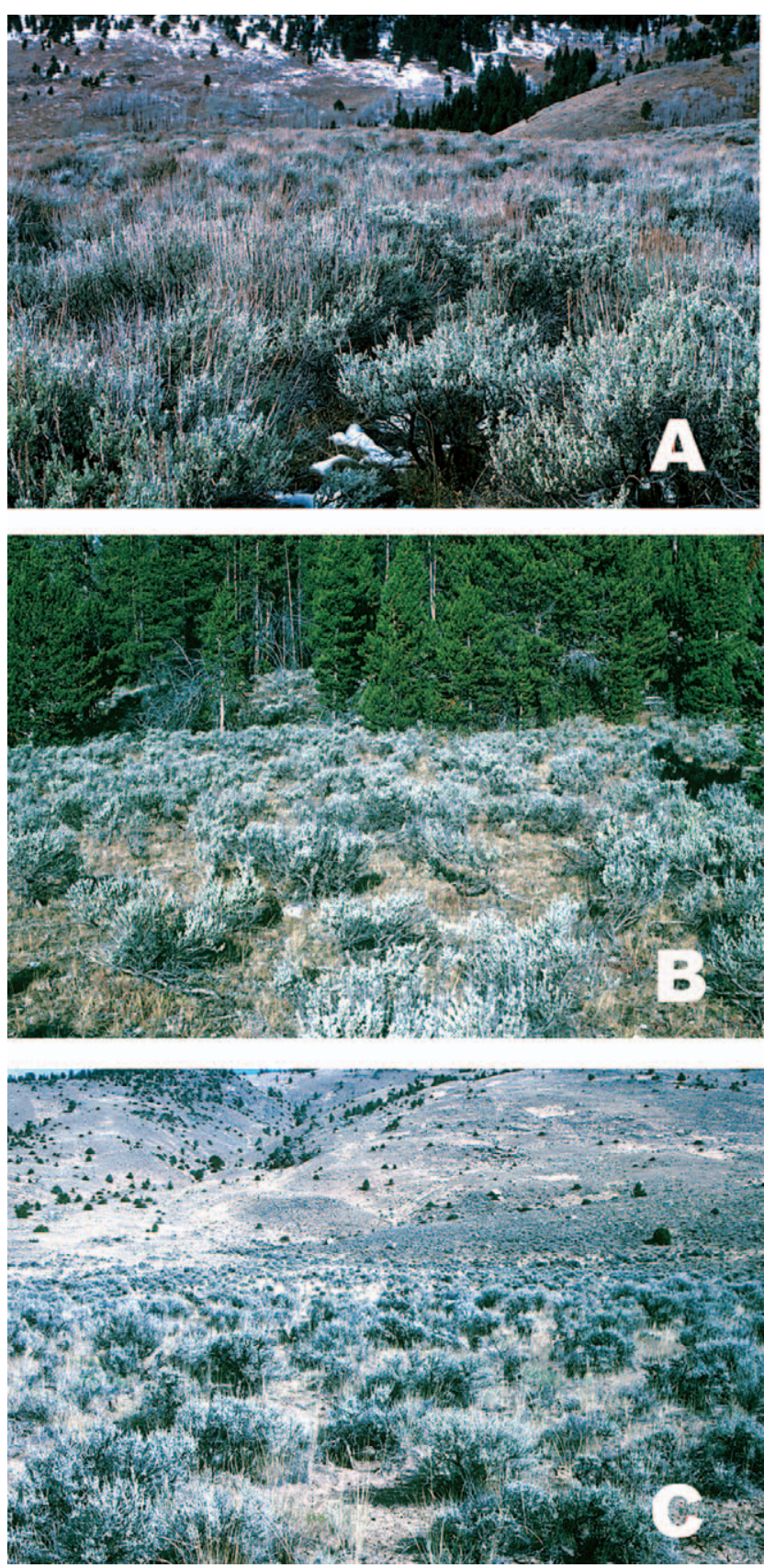

Figure 2. Although these photographs were not taken on range currently occupied by sage-grouse, they illustrate a concern with the SRM issue paper, ${ }^{3}$ which contained photographs of mountain big sagebrush stands and which stated that cover was 15\% and 34\% and that canopy cover should not exceed 15\% (discussed in text). A, Mountain big sagebrush cover of $23 \%$ and $\mathbf{B}$, cover of $13 \%$ for the same taxon. C, Wyoming big sagebrush with a cover of $11 \%$. The method of cover determination at our sites followed a method commonly used in research from which management recommendations have been based. ${ }^{20}$ This demonstrates the need to be precise with such critical parameters. The plant community in $\mathbf{A}$ had significantly more herbaceous production than the other sites despite the highest sagebrush cover.

about sustainability. ${ }^{17}$ Similarly, Crawford et al ${ }^{4}$ stated that "generalizing a specific level of utilization that represents 'proper use' can be difficult" (p. 10). 


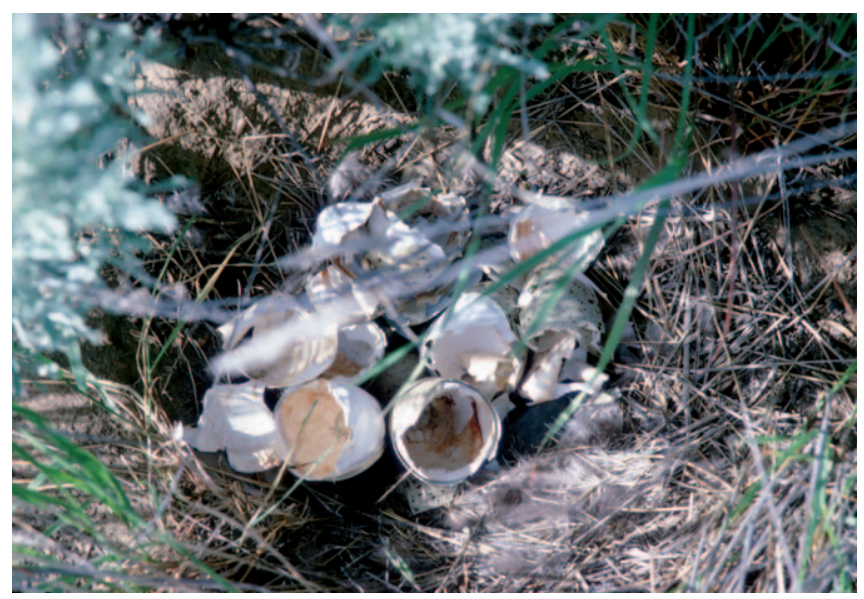

Figure 3. Successful nests often depend on the cover of both sagebrush and herbaceous vegetation, as is illustrated with this nest in northcentral Washington. The most efficient strategy to manage predators is with vegetation. ${ }^{4}$

$\mathrm{SRM}^{3}$ also stated that prescribed livestock grazing can be used to control invasive weeds and reduce wildfire risks. Although this statement is discussed in Crawford et al, ${ }^{4}$ the authors stated that: "the logistics of applying such grazing treatments at large spatial scales remain difficult" (p. 12). In addition, if livestock remove enough cover to significantly reduce the risk of fire, they may also damage the potential of the habitat to support sage-grouse. ${ }^{18}$ Virtually all of the wildfires occurring in sage-grouse habitat during the past 15 years have been in areas grazed by domestic livestock. ${ }^{5}$

\section{Factors Other Than Habitat That Affect Sage- Grouse Populations}

The issue paper ${ }^{3}$ implies that a lack of predator control is an important negative factor for sage-grouse, but there is little published information to support this view. Crawford et $\mathrm{al}^{4}$ briefly discussed predator control but primarily in relation to its complicated nature and the difficulty of interpreting the effects from multiple simultaneous manipulations. In fact, Crawford et $\mathrm{al}^{4}$ do not recommend predator control as was done in SRM. ${ }^{3}$ Rather, Crawford et $\mathrm{al}^{4}$ stated that "adequate vegetation structure at the nest site provides visual, scent, and physical barriers between ground-nesting birds and predators and may ultimately determine susceptibility to predation" (p. 6) (Fig. 3). Predation is a normal environmental variable, and the fact that it occurs does not automatically indicate that it is a problem. Thus far, there are only a few isolated areas where sage-grouse vital rates (adult survival, nest success, chick survival) appear to have been affected by predation, but often these have been related to both habitat fragmentation and the introduction of nonnative predators.

The issue paper ${ }^{3}$ introduces the topic of potential competition between nonnative species of game birds, such as the gray partridge (Perdix perdix), the chukar (Alectoris chukar), and the ring-necked pheasant (Phasianus colchicus). This topic was not mentioned by Crawford et $\mathrm{al}^{4}$ and is not sup- ported by peer-reviewed literature. This does not mean this issue should not be considered in future research. However, a thorough examination of potential competition from nonnative species would also consider the competitive effects of other sympatric nonnative species, including cattle, horses, and sheep.

\section{Landscape Issues}

$\mathrm{SRM}^{3}$ stated: "Sage-grouse do not thrive where large homogenous stands of any single plant species occupy the bulk of the landscape" (p. 6). The actual quote from Crawford et $\mathrm{al}^{4}$ is "Sage-grouse is not a species that can thrive only where large homogeneous stands of any single plant species occupy the bulk of the landscape" (p. 13). In the latter quote, sage-grouse can thrive in a homogenous landscape, and, in the former quote, they cannot. Nevertheless, both Crawford et $\mathrm{al}^{4}$ and $\mathrm{SRM}^{3}$ stated that the proportion of optimal seasonal habitats in a landscape is unknown, thus illustrating the complicated nature of the relationship between sage-grouse and their landscape. The reason why this relationship is poorly understood is that it likely varies by region, season, weather, population, suitability, and configuration of habitats within the landscape and by the landscape scale that is being examined. ${ }^{4}$ For example, in winter, a relatively large homogeneous stand of crested wheatgrass (Agropyron cristatum) or cheatgrass (Bromus tectorum) would undoubtedly be negative, whereas a large area of sagebrushdominated rangeland would be positive.

\section{Final Thoughts}

$\mathrm{SRM}^{3}$ used this section to relate sage-grouse numbers in the past with hunting regulations, implying that increases in populations followed closures or restrictions of hunting seasons in several western states. Crawford et $\mathrm{al}^{4}$ did not discuss this issue, and the issue has not been examined by any other authors, primarily because there are few published population data sets for the region before $1965 .{ }^{5}$ Moreover, if one were to make the assumption that $\mathrm{SRM}^{3}$ was correct in its assessment of range-wide populations of sage-grouse from the 1930s through the 1960s, equally plausible explanations would be that the establishment of grazing districts, through the Taylor Grazing Act of 1934, led to sage-grouse population increases, and long-term efforts to remove sagebrush and/or to establish crested wheatgrass contributed to declines.

\section{Conclusions}

We believe it is important for science-based professional societies to produce nontechnical information to reach a broader public so that the public understands the results and implications of research. We commend SRM for pursuing this form of outreach with sage-grouse, as it has with other issue papers (eg, rangelands and global change ${ }^{19}$ ). However, in doing so, a Society also has the obligation to use the bestavailable information and to present that information in an 
unbiased and unambiguous fashion. The preponderance of unreferenced material and unsupported interpretations undermines the intention of the SRM issue paper. ${ }^{3}$ Although distributing a nontechnical informational brochure on sage-grouse could be useful, the information contained in this issue paper $^{3}$ confuses and contradicts the body of knowledge surrounding management of these species and their habitat. Therefore, we suggest that SRM consider revising and redistributing this issue paper, ${ }^{3}$ using recent information, presented in a clear and concise fashion. Doing so will enhance the stature of SRM as a science-driven organization that is a leader in the proper stewardship of our nation's rangeland resources.

Authors are Research Scientist, Washington Department of Fish and Wildlife, PO Box 1077, Bridgeport,WA 98813, schromas@ dfw.wa.gov (Schroeder); Principal Wildlife Research Biologist, Idaho Department of Fish and Game, Department of Biological Sciences, Idaho State University, Pocatello, ID 83209 (Connelly); Professor of Range Science, Department of Animal and Range Sciences, Montana State University, Bozeman, MT 59717 (Wambolt); Director, Grouse Inc, 5572 North Ventana Vista Road, Tucson, AZ 85750 (Braun); Sage-Grouse Coordinator, Oregon Department of Fish and Wildlife, 61374 Parrell Road, Bend, OR 97702 (Hagen); and Range and Habitat Coordinator, Montana Department of Fish, Wildlife and Parks, 1330 West Gold Street, Butte, MT 59701 (Frisina).

\section{References}

1. Schroeder, M. A., C. L. Aldridge, A. D. Apa, J. R. Bohne, C. E. Braun, S. D. Bunnell, J. W. Connelly, P. A. Deibert, S. C. Gardner, M. A. Hilliard, G. D. Kobriger, S. M. McAdam, C. W. McCarthy, J. J. McCarthy, D. L. Mitchell, E. V. Rickerson, And S. J. Stiver. 2004. Distribution of sage grouse in North America. Condor 106:363-376.

2. Wambolt, C. L., A. J. Harp, B. L. Welch, N. Shaw, J. W. Connelly, K. P. Reese, C. E. Braun, D. A. Klebenow, E. D. McArthur, J. G. Thompson, L. A. Torell, and J. A. TANAKA. 2002. Conservation of greater sage-grouse on public lands in the western U.S.: Implications of recovery and management polices. Caldwell, ID: Policy Analysis Center for Western Public Lands. Policy Paper SG-02-02.

3. Society for Range Management. 2005. Ecology and management of sage-grouse and sage grouse habitat: Issue paper created by the Society of Range Management. Wheat Ridge, CO: Society for Range Management.

4. Crawford, J. A., R. A. Olson, N. E. West, J. C. Mosley, M. A. Schroeder, T. D. Whitson, R. F. Miller, M. A. GregG, AND C. S. BOYD. 2004. Ecology and management of sage- grouse and sage-grouse habitat. Journal of Range Management $57: 2-10$.

5. Connelly, J. W., S. T. Knick, M. A. Schroeder, And S. J. STIVER. 2004. Conservation assessment of greater sage-grouse and sagebrush habitats. Cheyenne, WY: Western Association of Fish and Wildlife Agencies. Unpublished Report.

6. Young, J. R., C. E. Braun, S. J. Oyler-McCance, J. W. HupP, AND T. W. Quinn. 2000. A new species of sage-grouse (Phasianidae: Centrocercus) from southwestern Colorado. Wilson Bulletin 112:445-453.

7. HuPP, J. W. AND C. E. BRAUn. 1989. Topographic distribution of sage grouse foraging in winter. Journal of Wildlife Management 53:823-829.

8. Connelly, J. W., M. A. Schroeder, A. R. Sands, And C. E. BRAUN. 2000. Guidelines to manage sage grouse populations and their habitats. Wildife Society Bulletin 28:967-985.

9. Wambolt, C. L., M. R. Frisina, S. J. Knapp, and R. M. FRISINA. 2006. Effect of method, site, and taxon on line-intercept estimates of sagebrush cover. Wildlife Society Bulletin 34 (in press).

10. Wakkinen, W. L., K. P. Reese, and J. W. Connelly. 1992. Sage grouse nest locations in relation to leks. Journal of Wildlife Management 56:381-383.

11. Braun, C. E., T. Britt, and R. O. Wallestad. 1977. Guidelines for maintenance of sage grouse habitats. Wildlife Society Bulletin 5:99-106.

12. Holloran, M. J. 2005. Greater sage-grouse population response to natural gas field development in western Wyoming [dissertation]. Laramie, WY: University of Wyoming. 211 p.

13. Connelly, J. W., K. P. Reese, R. A. Fischer, and W. L. WAKKINEN. 2000. Response of a sage-grouse breeding population to fire in southeastern Idaho. Wildlife Society Bulletin 28:90-96.

14. KLEBENOW, D. A. 1970. Sage grouse versus sagebrush control in Idaho. Journal of Range Management 23:396-400.

15. BAKER, W. L. 2006. Fire and restoration of sagebrush ecosystems. Wildlife Society Bulletin 34 (in press).

16. Heitschmidt, R. K., L. T. Vermeire, and E. E. Grings, 2004. Is rangeland agriculture sustainable? Journal of Animal Science 82(Electronic Suppl):E138-E146.

17. Fleischner, T. L. 1994. Ecological costs of livestock grazing in western North America. Conservation Biology 8:629-644.

18. BECK, J. L. AND D. L. MitChELL. 2000. Influences of livestock grazing on sage grouse habitat. Wildlife Society Bulletin 28:993-1002.

19. Brown, J. R., R. R. Blank, G. R. McPherson, and K. W. TATE. 2005. Rangelands and global change: Issue paper created by the Society of Range Management. Wheat Ridge, CO: Society for Range Management.

20. Connelly, J. W., K. P. Reese, And M. A. Schroeder. 2003. Monitoring of greater sage-grouse habitats and populations. Moscow, ID: University of Idaho, College of Natural Resources Experiment Station Bulletin 80. 


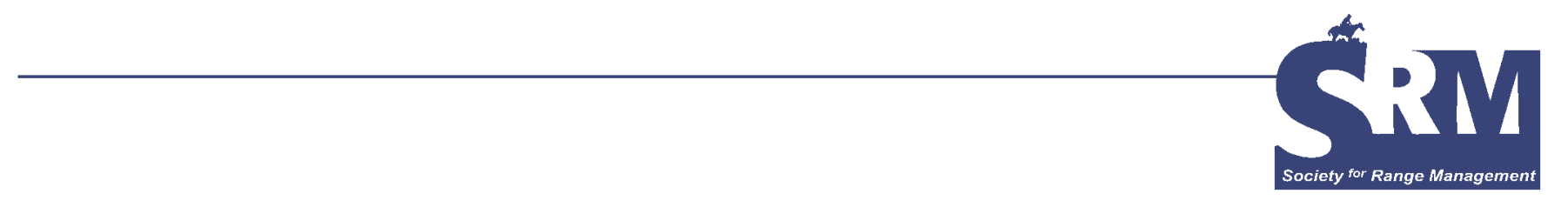

\section{The Effect of Cattle Grazing on Native Ungulates: The Good, the Bad, and the Ugly}

By Natalia A. Chaikina and Kathreen E. Ruckstuhl

\section{Introduction}

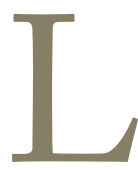

ivestock grazing pressure on native vegetation has been an important concept for many rangeland managers, as well as livestock owners, for many years. One particular question addresses the effects of cattle grazing on native ungulates, such as deer, elk, and bighorn sheep. Multiple studies had demonstrated that some level of cattle grazing could cause a decrease in forage availability for wild ungulates, such as mule deer (Ocodoileus hemionus), ${ }^{1,2}$ bighorn sheep (Ovis canadensis), ${ }^{3}$ and elk (Cervus elaphus). ${ }^{4}$ Several studies indicate a direct forage competition between cattle and native ungulates, such as elk, ${ }^{5}$ deer, ${ }^{5}$ mule deer, ${ }^{6}$ and, in the Indian TransHimalaya, wild bharal (Pseudois nayaur). ${ }^{7}$ Overgrazing can also cause a change in range structure, for example by decreasing hiding cover for mule deer. ${ }^{8}$ Intense cattle grazing has been associated with lower weights and reduced fat content and reproductive rates in female white-tailed deer (Odocoileus virginianus); it also had negative impacts on translocation success of bighorn sheep, ${ }^{10}$ and decreased white-tailed deer survival. ${ }^{11}$

Although many examples indicate negative impacts of cattle grazing on wild ungulates, the effects of grazing on range conditions are not always clear. The objective of this review is to address the following questions:

This article has been peer reviewed.

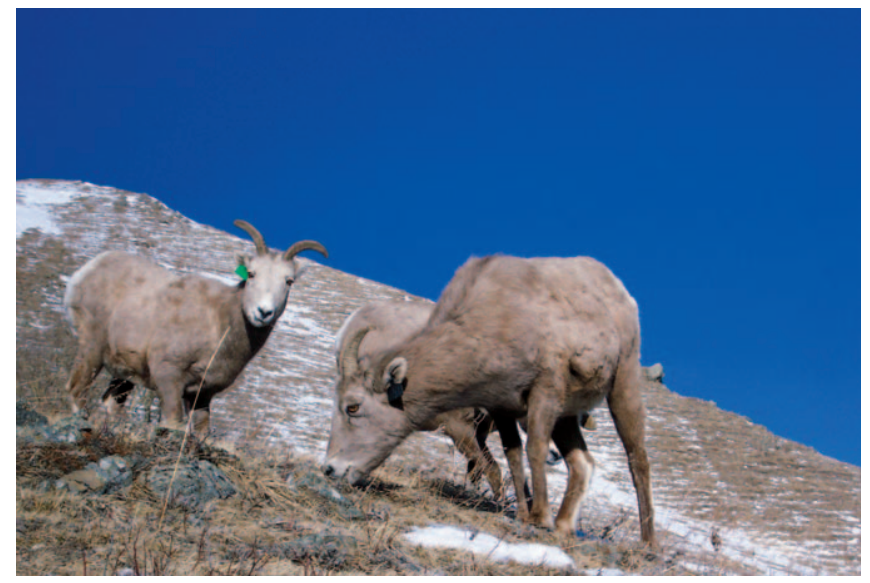

Group of female bighorn sheep grazing on the slope of a hill. Photo courtesy of Natalia Chaikina.

Has livestock grazing consistently been shown to be detrimental in the past, or are there cases where grazing had no consequences or was beneficial to native ungulates?

In cases where grazing was found to be beneficial, what timing and intensity of the application produced the best effects?

If grazing was detrimental, in which ways did it affect the big game animals and how is it possible to reduce or eliminate these damaging impacts?

Is it possible to find an acceptable balance between preservation of the environment and economic benefits of cattle production? 


\section{The Impact Sources}

\section{Diet Overlap}

One of the first questions that needs to be investigated is whether or not there is forage competition between cattle and native ungulates. Competition for resources requires these 2 groups to have dietary and spatial overlap, as well as limited resources. ${ }^{12}$ Many studies have found potential diet overlap between cattle and big game animals, but there is great variation in results depending on wild game species, areas of study, and time of the year. Campbell and Johnson ${ }^{13}$ looked at the dietary overlap between cattle, mule deer, and mountain goats (Oreamnos americanus) on Chopaka Mountain, Washington. They found that most overlap occurred between mountain goat and mule deer diets (37\%) and mountain goat and cattle diets (32\%). There was least overlap between diets of mule deer and cattle (15\%). Olsen and Hansen ${ }^{14}$ as well as Mackie $^{15}$ found a large diet overlap between cattle and elk. Hansen and Reid ${ }^{16}$ found some diet overlap, up to $48 \%$ between deer and elk, 38\% between deer and cattle, and 51\% between elk and cattle in southern Colorado. Willms et a ${ }^{17}$ reported that cattle and deer had significant range overlap in British Columbia, because both used mainly open forests and clearings. Even though diet overlap between livestock and deer was not high, it increased as forage became less available.

On the other hand, Kingery et a $1^{18}$ reported that cattle and elk in northern Idaho foraged mainly on graminoids, even though elk exhibited a broader diet range than cattle. Whitetailed deer consumed mainly forbs and shrubs. There was some potential competition between elk and cattle, but not between cattle and deer in this case. Pordomingo and Rucci ${ }^{19}$ argued that, with proper management, cattle and deer can use the same ranges with minimal competition. Deer are more adapted to browsing and selecting better quality plants and cattle have better ability to digest low-quality grasses. Stewart et $\mathrm{al}^{20}$ used stable isotopes from fecal samples of cattle, elk, and mule deer in order to show significant differences in diets of these 3 species in western North America. Hansen et $\mathrm{al}^{21}$ reported a small diet overlap between cattle and deer in the Douglas Mountain area, Colorado.

Even though cattle and wild ungulates focus on different kinds of vegetation, diet overlap increases when forage becomes less available, which usually happens in winter and early spring. For example, Thill and Martin ${ }^{22}$ showed that diet overlap between white-tailed deer and cattle on pastures in central Louisiana was greatest in the winter (30.7\%). However, the intensity of cattle grazing did not have a major impact on the diet overlap. The study suggests that late fall and winter cattle grazing can be detrimental to the availability of forage for deer. Thill ${ }^{23}$ also suggested that white-tailed deer and cattle diets on the forest sites had the greatest overlap during winter and spring seasons. Ortega et $\mathrm{al}^{24}$ looked at diet overlap between deer and cattle in Texas. Greatest overlap (60\%) was also found to occur in the winter and spring, under limited forage conditions, that resulted from shortduration heavy stocking treatment.

\section{Physical Presence of Cattle}

Grazing, as well as the physical presence of cattle, can have negative impacts on wild ungulates not only through vegetation limitation, but by causing behavioral changes and altering activity budgets that make foraging less productive. Bissonette and Steinkamp ${ }^{25}$ reported that California bighorn sheep in Big Cottonwood Canyon, Idaho, avoided cattle and decreased use of areas when cattle were in a close proximity. $\mathrm{Kie}^{26}$ found that intensity of cattle grazing pressure in California altered activity budgets of female mule deer, especially during late fall and winter when forage was limited in supply. A study of female mule deer in California's Sierra Nevada showed that deer exhibited avoidance behavior and temporal partitioning of habitat use when cattle were present. ${ }^{27}$ Stewart et $\mathrm{al}^{28}$ reported cattle avoidance behavior by elk and mule deer, who adjusted their use of the area, moving away from cattle, possibly to avoid forage competition. White-tailed deer in Louisiana altered their winter diets on sites that were continuously grazed by cattle by selecting more herbs and less browse. ${ }^{29}$ Another study done by Crimella et a ${ }^{30}$ on red deer (Cervus elaphus) showed that deer spent less time resting and feeding when cattle were present. Deer also spend more time foraging on the areas previously grazed by cattle. Wild ungulates can also exhibit a change of range use because of the presence of cattle. Loft et $\mathrm{al}^{31}$ studied female mule deer distribution in the Sierra Nevada of California in relationship to cattle grazing. The study showed that under no cattle grazing pressure deer preferred meadows and riparian habitat whereas, on moderately and heavily grazed ranges, deer used more montane shrub habitat. Yeo et $\mathrm{al}^{32}$ reported that elk and mule deer changed their habitat use as a result of rest-rotation cattle grazing in east-central Idaho.

Some studies, however, indicate little behavioral change. For example, Halstead et a ${ }^{33}$ showed that elk choice of grazing areas in central Arizona was more dependent on tree growth patterns and terrain features than on the presence or absence of cattle grazing in the area. Skovlin et $\mathrm{al}^{34}$ showed

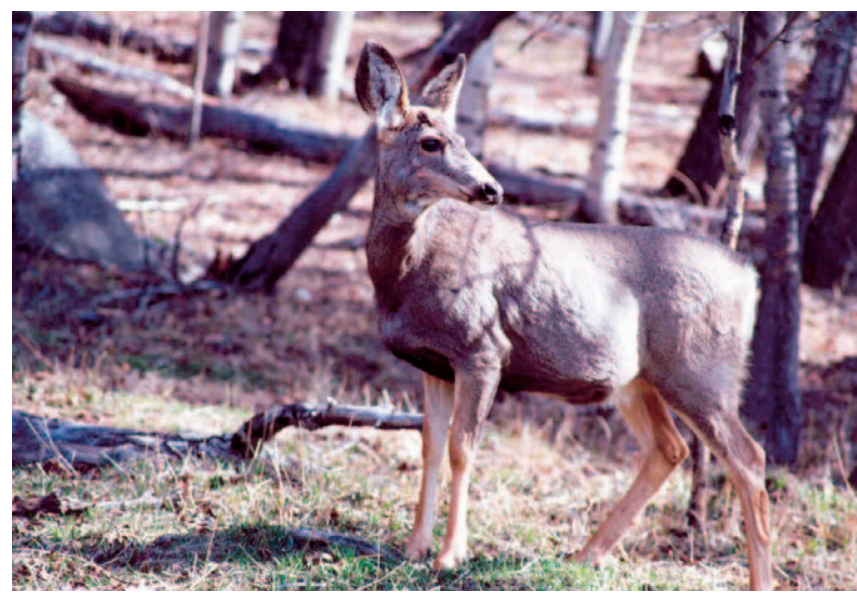

Female mule deer in the forest. Photo courtesy of Kathreen Ruckstuhl. 


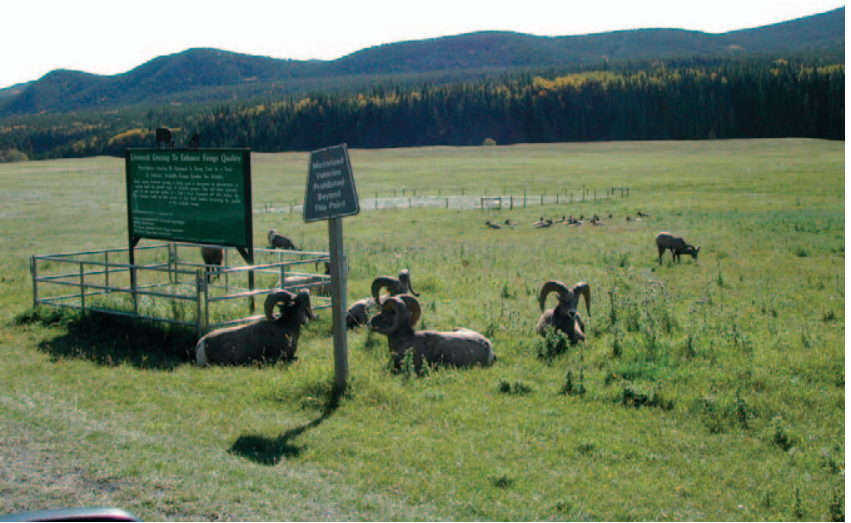

Group of male bighorn sheep lying by the cattle exclosure in the hayfields. Photo courtesy of Kathreen Ruckstuhl.

that both elk and deer range use was minimally altered under light and moderate stocking rates.

\section{Impact Indicators}

\section{Avoidance of Areas Grazed by Cattle}

Some studies have reported that wild ungulates may avoid areas used by cattle. Bowyer and Bleich ${ }^{2}$ observed fewer mule deer and less pellet groups on the grazed areas. Clegg ${ }^{35}$ showed that elk preferred ungrazed areas during rest-rotation grazing systems in Utah. Similar conclusions were drawn from the studies on elk and mule deer in Oregon, ${ }^{36,37}$ elk in Montana, ${ }^{38,39}$ and mule deer in Arizona. ${ }^{40}$

On the other hand, some studies indicate little or no avoidance effect in wild ungulates resulting from cattle presence, possibly as a result of habituation. No avoidance was detected between mule deer and cattle in central Montana. ${ }^{41}$ Austin and Urness ${ }^{42}$ observed area selection, diet composition, and dietary nutrition of mule deer. Only a slight preference for ungrazed areas was found in the beginning of the trial, which diminished with prolonged deer use of the area (over 40 days). Hart et $\mathrm{al}^{43}$ looked at elk winter ranges that were also used by cattle in the summer. Researchers used light, moderate, and heavy grazing pressure as treatments. For all treatments, little habitat overlap was actually detected, because cattle preferred to use level lowland areas, whereas elk were concentrated mostly on the high steep areas. However, it is not known whether elk were found high up because they were actively avoiding areas grazed by cattle. No control areas without cattle grazing were used in this study.

\section{Timing and Intensity of Grazing}

At times, cattle grazing can have both positive and negative results. Westenskow-Wall et $\mathrm{al}^{44}$ investigated the effects of defoliation of bluebunch wheatgrass (Agropyron spicatum) that is used as forage by elk in the Blue Mountains of northeastern Oregon. Defoliation in fall helped to increase the digestibility and phosphorus concentration of the wheat- grass, but decreased the amount of forage available. However, Wambolt et $\mathrm{al}^{45}$ found that even though grazing slightly increased nitrogen and phosphorus contents of bluebunch wheatgrass, this effect was not noticeable during the following winter.

Sometimes cattle grazing might even temporarily increase the numbers of wild ungulates, which in turn negatively affects range health. For example, heavy cattle grazing coupled with low fire frequency in early 1960s in the United States led to an increase in antelope bitterbrush, which in turn caused an increase in mule deer numbers. ${ }^{46}$ However, overgrazing in the summer caused a nutrient deficiency for mule deer in the following early spring, and large numbers of mule deer contributed to the overgrazing by deteriorating soil and vegetation. ${ }^{47}$

\section{Positive Impacts of Cattle Grazing}

An overgrazed range was defined by Wilson and Macleod ${ }^{48}$ as an area "where there is a concomitant vegetation change and loss of animal productivity arising from the grazing of land by herbivores." However, there have been some instances where controlled cattle grazing not only had no detectable negative impacts, but was shown to improve forage quality for big game animals. Vavra and Sheehy ${ }^{49}$ argued that this is possible because grazing by cattle removes last year's growth, which in turn increases the protein content of new growth. Maximum range production is achieved by removing cattle early in the summer, allowing plants to regrow. Because new growth occurs in late summer, plants grazed in early summer are unable to complete their growth cycle and transfer nutrients to the roots. Nutrients are instead trapped in the shoots, which then makes them available for ungulate grazing. However, a year of rest in between grazing treatments is required for maximum production. A similar increase in vegetation quality can be achieved by vegetation removal through clipping. ${ }^{50}$ On the other hand, this temporary increase in nutrients might be lost during the winter, which is the most critical time for ungulates. ${ }^{45}$

Scotter ${ }^{51}$ suggested that range use by both livestock and big game can help achieve and sustain the balance of browse and herbaceous forage within plant communities, thus increasing economic benefits of the land. He also suggested that livestock grazing in early spring can increase the protein content and digestibility of forage for mule deer winter diets.

Anderson and Scheninger ${ }^{52}$ argued that a specifically designed cattle-grazing system was capable of increasing the amount and quality of winter vegetation, based on elk range in northeastern Oregon. The grazing system was designed to allow sufficient time between grazing periods for plants to regrow, as well as to carefully control the grazing intensity. After the establishment of the new resource management plan, there was an increase in the quality of winter forage for elk. Elk numbers that averaged at about 120 elk for 12 years increased up to 1,190 elk and the intensity of cattle grazing was increased by 2.6 times during that period. 
Another study done on cattle and white-tailed deer in Mexico suggests that a grazed area is more stable when it is used by 2 herbivore species with different foraging patterns than by a single herbivore species. ${ }^{53}$ Cattle grazing was also reported to aid forb production and increase deer abundance, ${ }^{54}$ to improve the nutritional status of white-tailed deer, ${ }^{55}$ to improve forage conditions on deer winter range, ${ }^{56}$ and to increase deer spring preference for the pastures that were grazed by cattle in the previous fall. ${ }^{57}$

Gordon $^{58}$ also showed that winter cattle grazing in Scotland caused an increase in the amount of new vegetation in the following spring. Red deer also preferred to graze in spring on the areas that were grazed by cattle in the previous winter and had more calves per hind living on grazed areas.

There are examples that show that complete removal of cattle may even cause forage stagnation and make ranges less suitable for wild ungulates. Tueller and Tower $^{59}$ define stagnation as "the reduction in productivity of range plants resulting from a lack of grazing." Brown and Martinsen ${ }^{60}$ determined that exclusive deer and elk use of the areas for 20 or more years in eastern Washington caused both a decline in forb and browse species and a change towards the climax bunchgrass vegetation type, making the ranges more suitable for cattle grazing and less optimal for wild ungulate use. Hudson et $\mathrm{a}^{61}$ also found that grazing by white-tailed deer, mule deer, elk, and bighorn sheep alone in southeastern British Columbia caused a community shift towards more herbs and less browse, making it less suitable for browsing ungulates.

\section{Economic Issues}

The picture would not be complete without addressing the issue of the best economic gain that can be obtained from an area used by both cattle and wild ungulates. For example, Bastian et $\mathrm{a}^{162}$ used a computer model to evaluate the best economic use of the Wyoming Red Desert. They found that the benefits of the area were maximized when cattle and antelope (Antilocapra americana) were allowed to graze together. Smith et $\mathrm{al}^{63}$ also suggests that dual use of the area by mule deer and domestic sheep (Ovis aries) would increase economic yield of the ranges. Economic models of mule deer foraging on Sierra Nevada summer range indicated that under a 3-year rest-rotation grazing management, increase in the amount of rest years (from 1 to 2 years) would increase mule deer population size. This would cause increased hunting and economic benefits that would cover the losses from reduced livestock. ${ }^{64}$

\section{Impact Mitigation}

The question is, if different grazing studies give such contrary results, is it possible to determine whether or not cattle and wild ungulates can coexist as part of a healthy system? What has to be taken into account is that different levels and systems of grazing can have different effects on the forage quality and availability for native ungulates. For example,

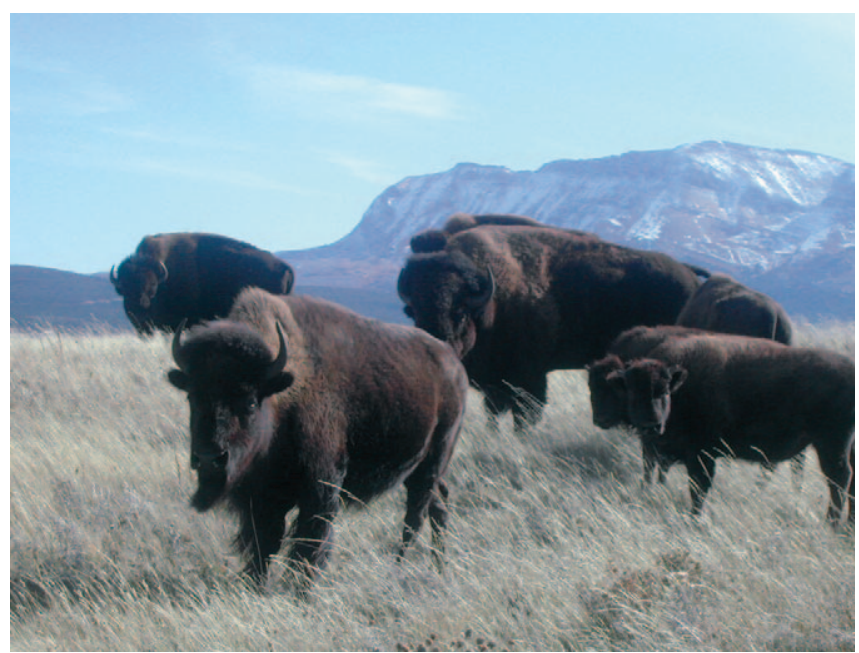

Group of bison in the prairies. Photo courtesy of Kathreen Ruckstuhl.

Cohen et $\mathrm{a}^{165}$ reported that short-duration grazing exerted more stress on white-tailed deer than did continuous grazing in southern Texas. Deer avoided cattle more and traveled more during short-duration grazing. Martinez et $\mathrm{al}^{66}$ found greater similarities between white-tailed deer and cattle diets on rotationally grazed ranges (23\%) than on continuously grazed ranges (15\%).

Another study looked at plant biomass on the ranges under short-term and continuous grazing, as well as under moderate and heavy grazing. ${ }^{24}$ Short-term grazing (when cattle are present on the range only during some part of the grazing season) is thought to be best for the range health, as it allows for the vegetation recovery. However, it was found that diet overlap between cattle and white-tailed deer increased under the short-term grazing system and that deer obtained more forbs in the continuously grazed ranges. Continuous grazing under moderate stocking rates was recommended in order to achieve better white-tailed deer management.

Timing of grazing applications is also important. Smith and Doell, ${ }^{63}$ who studied summer cattle grazing on mixedbrowse herbaceous ranges in Utah, reported that cattle grazing should be stopped by July 1 in order to avoid bitterbrush utilization by livestock and to allow enough forage for wild ungulates. Similar studies in northeastern Oregon showed that early summer cattle grazing has a minimal effect on mule deer and elk foraging efficiency. ${ }^{67}$

\section{Conclusion and Suggestions for Future Research}

In summary, this review has looked at 13 studies that showed a positive impact of cattle grazing, 31 studies that indicated a negative impact of grazing, and 23 studies that had inconclusive results. Note that the majority of the studies focused on the impact of grazing on deer, even though the diet overlap between deer and cattle is relatively small. Ungulates, such as elk, bighorn sheep, or bison, have a greater diet overlap with cattle. Future research should concentrate more on investigating the effects of cattle on ungulates that consume 
graminoids as part of their diets, because the impact of grazing should be greater for this group.

There is a great degree of inconsistency in methodology and conclusions among the results of different studies, which make comparisons difficult. One recommendation would be to come up with a systematic approach and a set of methodologies that should be used to assess the impact of cattle on ungulate range. One example of directly examining grazing competition between cattle and wild ungulates would be to exclude cattle from parts of the range. The establishment of cattle exclosures and corresponding control areas (where cattle can graze), would allow one to look at the preference of wild ungulates and to determine if grazing has an impact on big game range selection. It is possible that native ungulates might have adjusted their diets in order to compensate for cattle grazing pressure. If this was the case, then one would observe a switch-back in diet by native ungulates when cattle are excluded.

The key to establishing a sustainable grazing system, however, is to not only look at the impact of cattle grazing itself but to also assess required forage off-take by the wild ungulates. By including wild ungulates in the equation we can then account for the internal dynamics of the system. ${ }^{12}$ Uncontrolled heavy grazing by cattle will most likely cause range deterioration, decrease forage availability, and have negative effects on native herbivores. On the other hand, controlled continuous cattle grazing with light to moderate stocking levels that are stopped early in the summer would likely increase the vegetation quality and balance community composition in favor of forbs and browse, which would be beneficial for wild ungulates.

\section{Acknowledgments}

We would like to thank an anonymous referee for valuable comments.

Authors are MSc Candidate,nchaikin@ucalgary.ca (Chaikina); and Professor (Ruckstubl), Department of Biological Sciences, University of Calgary, Calgary, Alberta, Canada T2N1N4. Research was funded by Discovery Grant 316189-2005 RGPIN from the Natural Sciences and Engineering Research Council of Canada and an Alberta Graduate Scholarship, University of Calgary. Funding was also obtained from Parks and Protected Areas.

\section{Literature Cited}

1. Austin, D. D., P. J. Urness, And L. C. Fierro. 1983. Spring livestock grazing affects crested wheatgrass regrowth and winter use by mule deer. Journal of Range Management 36:589-593.

2. BOWYER, R. T., AND V. C. BLEICH. 1984. Effects of cattle grazing on selected habitats of southern mule deer Odocoileus hemionus fuliginatus. California Fish and Game 70:240-247.

3. DeMArchi, D. A. 1973. Relationship of range quality to range condition in the Chilcotin region, British Columbia. Journal of Range Management 26:345-348.
4. Skovlin, J. M., P. J. Edgerton, and B. R. McConnell. 1983. Elk use of winter range as affected by cattle grazing, fertilizing, and burning in southeastern Washington. Journal of Range Management 36:184-189.

5. Loomis, J., D. Donnelly, And C. Sorg-Swanson. 1989. Comparing the economic value of forage on public lands for wildlife and livestock. Journal of Range Management 42:134-138.

6. Dasmann W. P. 1949. Deer-livestock forage studies on the interstate winter deer range in California. Journal of Range Management 2:206-212.

7. Mishra, C., S. E. Van Wieren, P. Ketner, I. M. A. HeitKonig, And H. H. T. Prins. 2004. Competition between domestic livestock and wild bharal Pseudois nayaur in the Indian Trans-Himalaya. Journal of Applied Ecology 41:344-354.

8. Loft, E. R., J. W. Menke, J. G. Kie, and R. C. Bertram. 1987. Influence of cattle stocking rate on the structural profile of deer hiding cover. Journal of Wildlife Management 51(3):655-664.

9. JenKs, J. A., And D. M. Leslie, JR. 2003. Effect of domestic cattle on the condition of female white-tailed deer in southern pine-bluestem forests, USA. Acta Theriologica 48(1):131-144.

10. Singer, F. J., V. C. M. PAPOUChis, And K. A. Symonds. 2000. Translocation as a tool for restoring populations of bighorn sheep. Restoration Ecology 8(4S):6-13.

11. McMahan, C. A., And C. W. Ramsey. 1965. Response of deer and livestock to controlled grazing in central Texas. Journal of Range Management 18:1-6.

12. Vavra, M., M. J. Willis, And D. P. Sheehy. 1999. Livestock-big game relationships: conflicts and compatibilities In: K. L. Launchbaugh, K. D. Sanders, and J. C. Mosely [eds.]. Grazing behavior of livestock and wildlife. Station Bulletin 70. Moscow, ID: University of Idaho. p 130-136.

13. CAMPBell, E. G., AND R. L. Johnson. 1983. Food habits of mountain goats, mule deer, and cattle on Chopaka Mountain, Washington, 1977-1980. Journal of Range Management 36:488-491.

14. Olsen, F. W., AND R. M. Hansen. 1977. Food relations of wild free-roaming horses to livestock and big game, Red Desert, Wyoming. Journal of Range Management 30:17-20.

15. MACKIE, R. J. 1978. Impacts of livestock on wild ungulates. Transactions of the North American Wildlife and Natural Resources Conference 43:462-476.

16. Hansen, R. M., And L. D. ReID. 1975. Diet overlap of deer, elk, and cattle in southern Colorado. Journal of Range Management 28:43-47.

17. Willms, W., A. McLean, R. Tucker, And R. Ritcey. 1980. Deer and cattle diets on summer range in British Columbia. Journal of Range Management 33:55-59.

18. Kingery, J. L., J. C. Mosley, And K. C. Bordwell. 1996. Dietary overlap among cattle and cervids in northern Idaho forests. Journal of Range Management 49:8-15.

19. Pordomingo, A. J., AND T. Rucci. 2000. Red deer and cattle diet composition in La Pampa, Argentina. Journal of Range Management 53:649-654. 
20. Stewart, K. M., R. T. Bowyer, J. G. Kie, B. L. Dick, And M. BEN-DAVID. 2003. Niche partitioning among mule deer, elk, and cattle: do stable isotopes reflect dietary niche? EcoScience 10:297-302.

21. Hansen, R. M., R. C. Clark, and W. LaWhorn. 1977. Foods of wild horses, deer, and cattle in the Douglas Mountain area, Colorado. Journal of Range Management 30:116-118.

22. Thill, R. E., AND A. Martin, JR. 1989. Deer and cattle diets on heavily grazed pine-bluestem range. Journal of Wildlife Management 53:540-548.

23. Thill, R. E. 1984. Deer and cattle diets on Louisiana pine-hardwood sites. Journal of Wildlife Management 48:788-798.

24. Ortega, I. M., S. Soltero-Gardea, D. L. Drawe, and F. C. BRYANT. 1997. Evaluating grazing strategies for cattle: deer and cattle food partitioning. Journal of Range Management 50:622-630.

25. Bissonette, J. A., And M. J. SteinkamP. 1996. Bighorn sheep response to ephemeral habitat fragmentation. Great Basin Naturalist 56:319-325.

26. KIE, J. G. 1996. The effects of cattle grazing on optimal foraging in mule deer (Odocoileus hemionus). Forest Ecology and Management 88:131-138.

27. Loft, E. R., J. G. KIE, AND J. W. Menke. 1993. Grazing in the Sierra Nevada: home range and space use patterns of mule deer as influenced by cattle. California Fish and Game 79:145-166.

28. Stewart, K. M., R. T. Bowyer, J. G. Kie, N. J. Cimon, And B. K. Johnson. 2002. Temporospatial distributions of elk, mule deer, and cattle: resource partitioning and competitive displacement. Journal of Mammalogy 83:229-244.

29. Thill, R. E., AND A. MARTIN. 1986. Deer and cattle diet overlap on Louisiana pine-bluestem range. Journal of Wildlife Management 50:707-713.

30. Crimella C., C. Carenzi, S. Mattiello, and W. Redaelli. 2002. Effect of dairy cattle husbandry on behavioural patterns of red deer (Cervus elaphus) in the Italian Alps. Applied Animal Behaviour Science 79:299-310.

31. Loft, E. R., J. W. Menke, And J. G. KiE. 1991. Habitat shifts by mule deer: the influence of cattle grazing. Journal of Wildlife Management 55:16-26.

32. Yeo, J. J., J. M. Peek, W. T. Wittinger, and C. T. Kvale. 1993. Influence of rest-rotation cattle grazing on mule deer and elk habitat use in east-central Idaho. Journal of Range Management 46:245-250.

33. Halstead, L. E., L. D. Howery, G. B. Ruyle, P. R. KrausMAN, AND R. J. STEIDL. 2002. Elk and cattle forage use under a specialized grazing system. Journal of Range Management 55:360-366.

34. Skovlin, J. M., P. J. Edgerton, And R. W. Harris. 1968. The influence of cattle management on deer and elk. Transactions of the North American Wildlife and Natural Resources Conference 33:169-181.

35. ClegG, K. 1994. Density and feeding habits of elk and deer in relation to livestock disturbance [MS thesis], Logan, UT: Utah State University. $41 \mathrm{p}$.
36. Coe, P. K., B. K. Johnson, J. W. Kern, S. L. Findholt, J. G. KIE, AND M. J. WisDOM. 2001. Responses of elk and mule deer to cattle in summer. Journal of Range Management 54:A51-A76.

37. Coe, P. K., B. K. Johnson, K. M. Stewart, and J. G. Kie. 2004. Spatial and temporal interactions of elk, mule deer, and cattle. Transactions of the North American Wildife and Natural Resource Conference 69: 656-669.

38. FrisinA, M. R. 1992. Elk habitat use within a rest-rotation grazing system. Rangelands 14:93-96.

39. Knowles, C. J., AND R. B. CAmpbell. 1981. Distribution of elk and cattle in a rest-rotation grazing system. In: J.M. Peek and P.D. Dalke [eds.]. Wildlife-Livestock Relationships Symposium: Proceedings 10. Moscow, ID: University of Idaho, Forestry, Wildlife and Range Experimental Station. p 47-60.

40. Ragotzkie, K. E., AND J. A. Bailey. 1991. Desert mule deer use of grazed and ungrazed habitats. Journal of Range Management 44:487-490.

41. DuseK, G. L. 1975. Range relations of mule deer and cattle in prairie habitat. Journal of Wildlife Management 39:605-616.

42. Austin, D. D., AND P. J. URness. 1986. Effect of cattle grazing on mule deer diet and area selection. Journal of Range Management 39:18-21.

43. Hart, R. H., K. W. Hepworth, M. A. Smith, and J. W. WAGGONER, JR. 1991. Cattle grazing behavior on a foothill elk winter range in southeastern Wyoming. Journal of Range Management 44(3):262-266.

44. Westenskow-Wall, K. J., W. C. Krueger, L. D. Bryant, AND D. R. ThOmas. 1994. Nutrient quality of bluebunch wheatgrass regrowth on elk winter range in relation to defoliation. Journal of Range Management 47:240-244.

45. Wambolt, C. L., M. R. Frisina, K. S. Douglass, and H. W. SHERWOOD. 1997. Grazing effects on nutritional quality of bluebunch wheatgrass for elk. Journal of Range Management 50:503-506.

46. Clements, C. D., And J. A. Young. 1997. A viewpoint: rangeland health and mule deer habitat. Journal of Range Management 50:129-138.

47. JUlAnder, O. 1962. Range management in relation to mule deer habitat and herd productivity in Utah. Journal of Range Management 15:278-281.

48. Wilson, A. D., And N. D. Macleod. 1990. Overgrazing: present or absent. Journal of Range Management 44(5):475-482.

49. VAVRa, M., AND D. P. Sheehy. 1996. Improving elk habitat characteristics with livestock grazing. Rangelands 18:182-185.

50. Garrison, G.A. 1953. Effects of clipping on some range shrubs. Journal of Range Management 6:309-317.

51. SCOTTER, G.W. 1980. Management of wild ungulate habitat in the western United States and Canada: a review. Journal of Range Management 33:16-27.

52. ANDERSON, E. W., AND R. J. SCHENINGER. 1975. Improving quality of winter forage for elk by cattle grazing. Journal of Range Management 28:120-125.

53. GallinA, S. 1993. White-tailed deer and cattle diets at $\mathrm{La}$ Michilia, Durango, Mexico. Journal of Range Management 46:467-492. 
54. Stuth, J. W., AND A. H. WinWard. 1977. Livestock-deer relations in the lodgepole pine-pumice region of central Oregon. Journal of Range Management 30:110-116.

55. Warren, R. J., AND L. J. KRYSL. 1983. White-tailed deer food habits and nutritional status as affected by grazing and deer-harvest management. Journal of Range Management 36:104-109.

56. Gibbens, R. P., And A. M. Schultz. 1962. Manipulation of shrub form and browse production in game range improvement. California Fish and Game 48:49-64.

57. Willms, W., A. Mclean, R. Tucker, And T. Ritchie. 1979. Interactions between mule deer and cattle on big sagebrush range in British Columbia. Journal of Range Management 32:299-304.

58. GoRDON, I. J. 1988. Facilitation of red deer grazing by cattle and its impact on red deer performance. Journal of Applied Ecology 25(1):1-10.

59. Tueller, P. T., AND J. D. Tower. 1979. Vegetation stagnation in three-phase big game exclosures. Journal of Range Management 32:258-263.

60. Brown, E. R., And C. F. Martinsen. 1967. Vegetational changes on some eastern Washington winter game ranges. Paper presented at the 20th annual meeting, American Society of Range Management; 13-17 February 1967; Seattle, WA. 9 p.

61. Hudson, R. J., D. M. Hebert, And V. C. Brink. 1976. Occupational patterns of wildlife on a major east Kootenay winter-spring range. Journal of Range Management 29:38-43.
62. Bastian, C. T., J. J. Jacobs, L. J. Held, and M. A. Smith. 1991. Multiple use of public rangeland: antelope and stocker cattle in Wyoming. Journal of Range Management 44:390-395.

63. Smith, A. D., AND D. D. Doell. 1968. Guides to allocating forage between cattle and big game on big game winter ranges. Salt Lake City, UT: Utah State Division of Fish and Game Publications 68-1. 32 p.

64. Loomis, J. B., E. R. Loft, D. R Updike, AND J. G. Kie. 1991. Cattle-deer interactions in the Sierra Nevada: a bioeconomic approach. Journal of Range Management 44:395-399.

65. Cohen, W. E., D. L. Drawe, F. C. Bryant, and L. C. BRADLEY. 1989. Observations on white-tailed deer and habitat response to livestock grazing in south Texas. Journal of Range Management 42:361-365.

66. Martinez, M. A., V. Molina, F. S. Gonzalez, J. S. MarroQUIN, AND J. NAVAR. 1997. Observations of white-tailed deer and cattle diets in Mexico. Journal of Range Management 50:253-257.

67. Damiran, D., T. DelCurto, S. L. Findholt, G. D. PulSIPHER, AND B. K. JOHNSON. 2003. Influence of previous cattle and elk grazing on the subsequent quality and quantity of diets for cattle, deer and elk grazing late-summer mixed-conifer rangelands. Proceedings of the Western Section, American Society of Animal Science 54:320-324. 


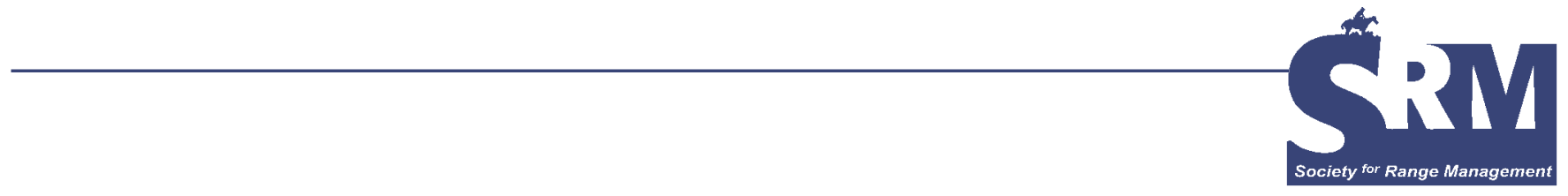

\section{Sage-Grouse at the Crossroads}

\section{By Jim Brunner}

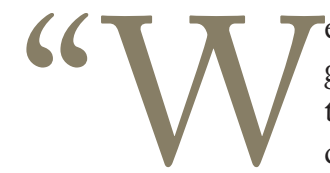

e find nests where the baby sagegrouse had hatched. Then we find their little bodies nearby, dead at 1 or 2 days old," said a spokesman for the Nevada Department of Wildlife. "And we don't understand why."

This appears to be the basic problem in the Intermountain Basin where sage-grouse are losing ground. Once the sage-grouse is 8 months old it is full grown, but getting it to this stage is the problem. The bird is beloved by almost every person who has ever seen or worked with birds. So it isn't benign neglect.

For the past few years, The American Lands Alliance of Washington, DC (a consortium of environmental groups ranging from the Audubon Society to the Sierra Club) has been beating the drums for listing the sage-grouse under the Endangered Species Act. The end goal of listing is removal of livestock from the sagebrush biome. Petitions have been submitted for both the greater sage-grouse and its smaller cousin, the Gunnison sage-grouse. The Gunnison was listed, but the greater sage-grouse was not. Will listing the bird help the grouse or will it ensure its demise? State wildlife agencies take a dim view of this effort to list.

Why would a state wildlife agency, staffed by dedicated wildlifers, object to a listing? Because then control of the land and the birds shifts to Washington, DC. The Endangered Species Act is concerned only with control of land uses and has had, to date, little or no effect on saving any species. A landowner simply cannot afford to have an endangered or threatened species on his land. He faces $\$ 75,000$ fines plus jail time if a bird is "harassed," ie, flushed as the person drives over his own land.
To get a feel for the sage-grouse, we must explore its needs and requirements. Should we start with the chicken or the egg?

The chicken? Okay. The female sage-grouse (hen) wanders into an established courting ground (lek). This must be a nearly bare, flat area so the birds can see each other, with escape cover from hawks nearby. She heads for the center of the lek, walking on the invisible line between various lesser males toward the center where the dominant males preen, blow out air sacs, and otherwise make themselves as conspicuous as possible. Some 20 to 50 males may be in attendance, but only a few central males do all the breeding. Males tend to return to the same lek each year, but hens shop around. (If you're interested, check with a state wildlife agency to see what tours are available to watch the strut on a cold February day.)

Once serviced, the hen scurries away into the thicker sagebrush and walks to choose a nesting site. If she is a virgin, she'll try most any site; if she's an older hen, she'll often go back to where she successfully nested before. Nest placement depends upon habitat and may be chosen before visiting the lek. Usually she'll go about a mile, but sometimes as much as 20. She'll have the best nest success if she chooses an area where sagebrush is scattered, about 14-20 inches tall. Here her nest is pretty well hidden. Several recent studies show that predation and cover are not closely linked. (The raven, a federally protected bird, is the major predator of sage-grouse nests.)

A week to 10 days after breeding, the hen lays a clutch of from 4 to 8 eggs; the average is 6 . She spends most of her time on the nest, leaving only during the warm parts of the day to feed on forbs and insects, the high-protein 
foods. Predators such as ravens, ground squirrels, badgers, and white-tail deer will eat the eggs or newly hatched chicks. As we learn more about the chicks, we find some die from no apparent cause. Some may be trapped in tall, coarse grass and starve. A chick, which is no larger than the first joint of your thumb, cannot fight its way through tall grass surrounding the nest. If the hen loses her nest to predation, she may well nest again and often this effort is successful.

Some scientists say chicks need free water for the first few days of life, others say no. It is undisputed the chicks must have insects to eat during the first 6 weeks if they are to survive. This high-protein diet is essential, which means they must have relatively bare ground where they can see, chase, and catch the ants, darkling beetles, and black beetles that are the dietary mainstay. Gradually the chicks eat high-protein forbs such as hawksbill, loco, or alfalfa. After the first killing frosts, the bird switches to sagebrush, preferring Lahontan sagebrush (Artemisia arbuscula longicaulis).

The surviving chicks grow rapidly and by fall they are nearly full-grown. Only about $50 \%$ will survive the first winter to enter the breeding flock. Where hunting is allowed, the hunters account for $2 \%$ to $5 \%$ of the birds. Predators and harsh weather kill the other $45 \%-48 \%$. The sage-grouse's natural reluctance to fly indicates that hawks and eagles take a heavy toll of the birds. Once through the first winter, the sage-grouse will often live another 8 to 10 years.

Overlooked in most studies is the preference of the sagegrouse for one subspecies of sagebrush during the summer, namely Lahonton sagebrush. Once winter comes the grouse shift to the ridges where the winds clear the snow. Here they eat alkali sagebrush, and thereafter their meat is no longer edible.

The Alliance suggests that removing cattle from western ranges will be the panacea for all problems. But almost all the water developed for livestock also waters birds and other wildlife. Without the rancher, these waters will not be maintained. The private land meadows were patented early and these are often prime strutting grounds for sage-grouse. Once the cattle are gone, then these lands must become prime development land for houses.

A great deal of empirical evidence indicates that cattle manure attracts and breeds insects. These insects in turn feed sage-grouse. Where there are no cattle, there are precious few birds. More empirical evidence indicates that sage-grouse follow the cattle as they are rotated between pastures. Not every year is a good year for forbs and when these are lacking the sage-grouse must substitute insects for forbs. A comparison of sage-grouse on the Sheldon Antelope Range (where cattle have been outlawed) and adjacent grazed lands show the flocks are healthier on grazed ranges. Forbs grow only on disturbed soil and cattle tracks provide havens for forb seed.

We should be aware of the natural 10-year boom-andbust cycle among sage-grouse and not panic when the birds seem to die off excessively.

So, how do you vote? Keep the birds or lose them? It's a political choice now.

Author is a charter member of SRM, a veteran of the former Soil Conservation Service (now the National Resources Conservation Service) and the Bureau of Land Management, and lives in Medford, Oregon, jimbrunner1@hotmail.com. 


\title{
Collaboration in the Borderlands: The Malpai Borderlands Group
}

\author{
After 10 years of efforts to preserve the open spaces and way of life of the Borderlands \\ Region, the Malpai Borderlands Group is now internationally recognized as an outstanding \\ example of collaborative planning and management of large landscapes.
}

\section{By Larry S. Allen}

\section{Roots of Change}

As our society is now increasingly polarized on the issues of natural resource use and protection of the environment, we endeavor to be at the Radical Center. -Bill McDonald

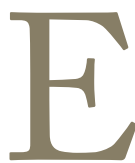
arly in the 1990s, several neighbors along the Mexican border in Southeastern Arizona and Southwestern New Mexico began to meet periodically at Warner and Wendy Glenn's Malpai Ranch. Bill McDonald called the meeting to order by tapping a spoon on his coffee cup. His gaze flitted over the tanned ranchers seated at the Glenn's dinner table. "You all know why we're here. We need to do something before the state and federal bureaucrats decide what to do with us. We all love our land and our lifestyle, and we're under siege from misguided environmentalists, who want to destroy our way of life with their upcoming 'Cattle Free in 93' campaign on the public lands." Other concerns included a top-down approach to management on the part of the myriad of state and federal land management agencies. Rancher Drummond Hadley invited some of his friends from the environmental community in New Mexico to join in the discussions, and several points of agreement were discovered. Strongest agreement was in the areas of preservation of open space and the need to restore fire as a functioning ecological process. It was agreed that livestock grazing requires open space and that preservation of the ranching industry is important to prevent habitat fragmentation.

The Malpai Planning Area includes 2 valleys at an elevation of about 4,000 feet, which support semidesert grassland and Chihuahuan desert scrub; 1 higher grassland valley (about 5,000 feet) with plains grassland; and 2 mountain ranges. Montane habitats include pinyon, juniper, live oaks,

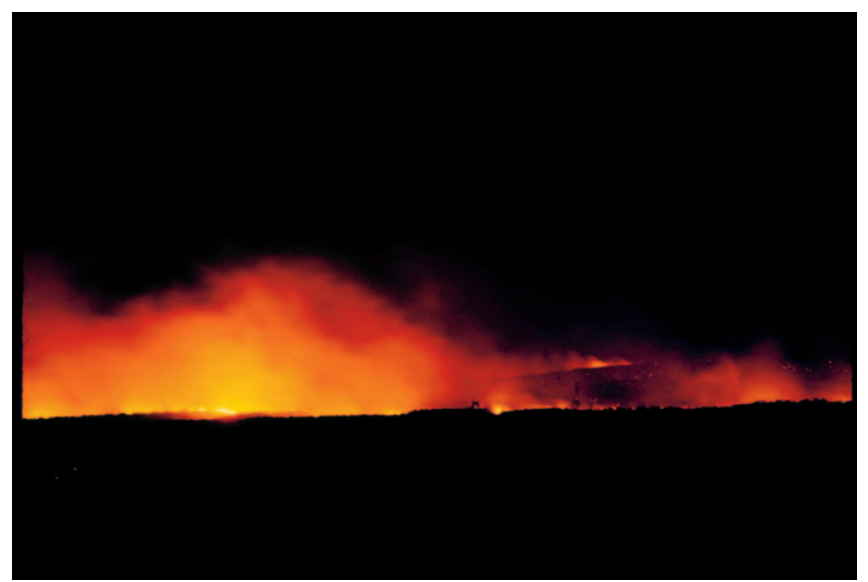




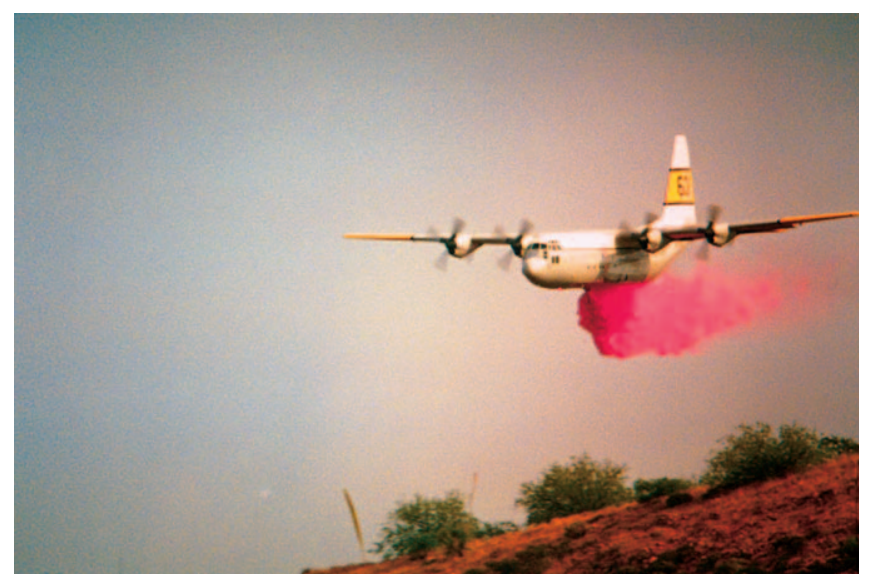

pines, and Douglas fir. Rainfall ranges from 12 to 25 inches annually. A mixture of native grasses produces from 1,000 to 2,500 pounds of forage per acre in an average year.

As this discussion group was forming, one event provided a catalyst for action. An airline pilot reported a wildfire along the road on the Rocker M Ranch. The fire was within an area that had been treated with herbicides to improve forage production and soil stability several years before. Shrubs were beginning to reinvade the site, and most neighbors perceived the fire as beneficial to maintain the brush control project. Adjacent to the area was a complete lack of fuels, with no danger of spread of the fire. Arizona State Land Department requested help from the US Forest Service, and an intensive suppression effort was conducted over the objections of the landowner/grazing permittee.

This fire event motivated the "Malpai Group" to poll the neighbors and produce a map indicating the desires of each local rancher concerning fire suppression. The map had 3 zones: 1) suppress immediately, 2) consult with owner, and 3) monitor. The group then requested a meeting with agency heads to discuss suppression policies. Representatives of Arizona State Land Department, the New Mexico State Forester, the Forest Service, the Soil Conservation Service, and the Bureau of Land Management in both states met with the group at Gray Ranch, New Mexico. The ranchers were pleasantly surprised to learn that agency personnel were in agreement that a change in suppression policy was needed. All agencies agreed to use a "Confine/Contain" strategy and to participate in landscape-scale fire planning. The result has been more than 250,000 acres of beneficial fires since 1993. The Malpai Borderlands Group (MBG) continues to annually interview the neighbors and to provide the agencies with an updated suppression map.

\section{The Malpai Borderlands Group}

It soon became apparent that the informal group needed more structure, and a meeting of all neighbors was called. The group was incorporated as a nonprofit corporation called The Malpai Borderlands Group and the following goal statement was developed:
Our goal is to restore and maintain the natural processes that create and protect an unfragmented, bealthy landscape to support a diverse, flourishing community of buman, plant and animal life in our borderlands region.

Together we will accomplish this by working to encourage profitable ranching and other traditional livelihoods, which will sustain the open space nature of our land for generations to come.

\section{Fire Planning}

The first major project undertaken by the group was a landscape-scale fire plan for the approximately 800,000-acre Malpai Borderlands Region. It was decided to divide the area into 4 planning units: 1) private and state lands in the New Mexico "boot-heel," 2) federal lands in the Peloncillo Mountains, 3) state and private lands in Arizona's San Bernardino Valley, and 4) Bureau of Land Management (BLM) and state lands in the Northwest portion of the planning area. Concurrently, supporters in the Mexican State of Sonora were undertaking similar planning.

- New Mexico State Forestry Department assumed responsibility for the "Boot-heel Plan" with close support from the Las Cruces District of BLM and the Animas Foundation. This plan was quickly completed, and it has undergone 1 revision.

- Coronado National Forest undertook planning for the federal lands (the Peloncillo Programmatic Fire Plan) with support from BLM's Safford District. This planning process has been under way since early 1997 . Progress has been slow and frustrating. Required consultation between the Forest Service and US Fish and Wildlife Service was completed in the spring of 2005, and the plan has been incorporated into the Coronado Forest Plan. Modification of BLM plans has not yet occurred.

- Arizona State Land Department and US Department of Agriculture (USDA) Natural Resource Conservation Service (NRCS) initiated planning for the San Bernardino Valley. Retirement of a key NRCS person has resulted in delays in completion.

- Safford BLM district assumed responsibility for the northwestern part of the area. This plan has not yet been initiated.

Fire planning includes consideration of wildfire suppression, management fires, and management ignited prescribed burns. This continues to be a priority for the Malpai Group.

\section{Help From Nongovernmental Organizations}

At the time of the formation of the Malpai Borderlands Group, The Nature Conservancy (TNC) purchased Diamond A Ranch in an attempt to preserve the tremendous biodiversity and wildlife habitats of the area. TNC immediately undertook an inventory and planning process for the ranch. Management of the 330,000-acre ranch soon became a significant drain on the financial resources of TNC, and it began to seek a "conservation buyer." This was a new 
approach for the conservation group, which has since become a common procedure.

TNC Vice President John Cook was sent to New Mexico to oversee the sale of this property with a conservation easement. After several months of seeking a suitable buyer, Drummond Hadley, one of the founding members of the Malpai Borderlands Group, was able to create a family foundation (the Animas Foundation) and purchase Diamond A Ranch, with conservation easements. In the process, John Cook became friends with the Hadley family and began to meet some of the neighbors.

The Animas Foundation has an objective of demonstrating sustainable agriculture in harmony with a healthy environment - an idea that was shared by the Malpai Group. The Animas Foundation became a strong supporter of the Malpai Group, with 2 of the Hadleys currently on the Board of Directors. John Cook's vast experience in organization and fund-raising proved invaluable to the group during the formative stages. He is currently a board member. The help and support from John Cook and TNC has long been one of the strengths of the Malpai Group.

\section{Collaborative Management in the Borderlands}

The group quickly realized that cooperative management of this complex landscape would require close liaison with the involved land management agencies. They persuaded the USDA Soil Conservation Service (now the NRCS) to appoint Range Conservationist Ron Bemis to be an agency representative. USDA Forest Service was convinced to make Range Ecologist Larry Allen available for a similar position. These 2 positions soon evolved into full-time jobs for Ron and Larry.

Many of the issues under consideration were based on science and the group came to the conclusion that all decisions needed to be based on the best available science. Board member Ray Turner was a respected ecologist and author, and he contributed to the organization of a science committee. Research Foresters Leonard DeBano and Carl Edminster, of the Forest Service's Rocky Mountain Experiment Station, were instrumental in establishing contacts and providing funding for needed research, including Dr Liz Slausen's study of fire impacts on Palmer Agave and Andy Holycross' studies of the New Mexico Ridge-nosed Rattlesnake. Sometime later, TNC Botanist Peter Warren was hired part-time, and Dr Charles Curtin was contracted to coordinate some of the science effort. Dr Ben Brown currently coordinates the science effort. Scientists from a number of agencies, universities, and private institutions have contributed to the group's understanding of the ecosystem.

Neighboring ranchers were encouraged to meet with the group and participate in planning for the future of the Borderlands. Presently, 10 of 13 board members are from the ranching community. An attempt has been made to include all federal, state, and local agencies involved in the area, and
Table 1. Organizations involved in the Malpai Borderlands Group
United States

Department of

Agriculture

Coronado National

Forest

Rocky Mountain

Experiment Station

Natural Resource

Conservation Service

Cooperative

Extension Service

Agricultural Research

Service

United States

Department of Interior

Bureau of Land

Management -

Safford

Bureau of Land

Management - Las

Cruces

US Geological

Survey - Desert Lab-

Tucson

US Fish and Wildlife

Service-AZ and NM

The Nature

Conservancy

The Animas Foundation

Ranching Community of Arizona, New

Mexico,

and Sonora
Hidalgo County, New Mexico

Cochise County, Arizona
Arizona State Land Department

New Mexico State Land Department

New Mexico State Forester
Arizona Department of Game and Fish

New Mexico

Department of Game and Fish

\begin{tabular}{|c|c|}
\hline and Sonora & $\begin{array}{l}\text { University of New } \\
\text { Mexico } \\
\text { New Mexico State } \\
\text { University }\end{array}$ \\
\hline & $\begin{array}{l}\text { Secretary of the } \\
\text { Environment - Sonora, } \\
\text { Mexico }\end{array}$ \\
\hline
\end{tabular}


academia, nongovernmental organizations, and interested citizens as collaborators. This diversity has created a strong and effective organization. Involved organizations are listed in Table 1.

\section{On-the-Ground Management}

The Malpai Group has always considered itself to be a "hands-on" management organization as opposed to a planning group. While collaborative planning has been under way, the group has initiated a number of projects.

\section{Shrub Control}

Encroachment of woody plants into grasslands and an increase in the density of woodlands are some of the major problems facing the group. Areas on Malpai Ranch and Magoffin Ranch were cleared of desert shrubs and seeded to native grasses. Several experimental plots have been estab-

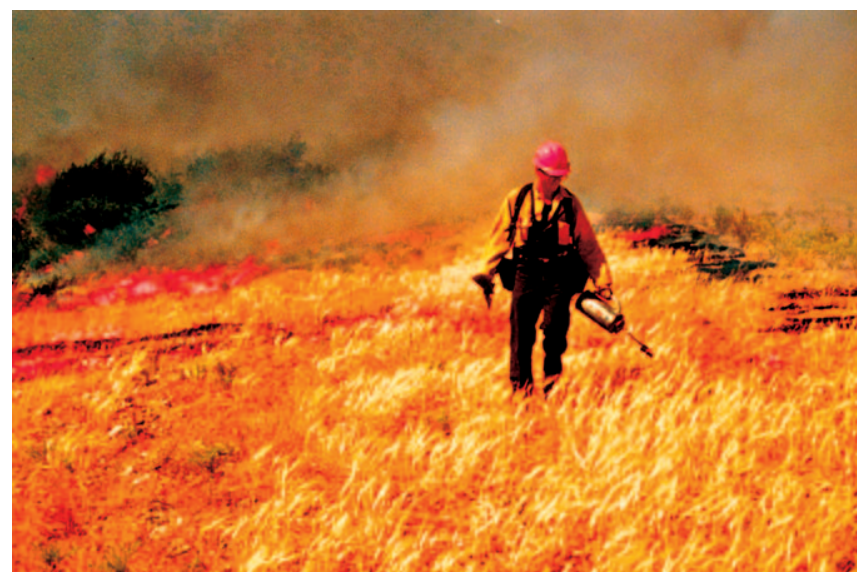

lished in the area to test shrub-control techniques. Three significant, prescribed burns- the 6,000-acre Baker Burn, the 12,000-acre Maverick Burn, and the 43,000-acre Baker II Burn - have been conducted to thin shrubs and trees and reduce fuel loading. The Baker II Burn is thought to be the largest management-ignited fire in US history.

\section{Wildlife Management}

Several miles of old, net-wire, domestic sheep fence were replaced with a state-of-the-art, "wildlife friendly," 4-strandbarbwire fence in a cooperative project jointly funded by a rancher, the Malpai Borderlands Group, and the BLM.

New Mexico Department of Game and Fish reintroduced desert bighorn sheep on the Miller Ranch in the Peloncillos. Bill and Carol Miller conduct much of the monitoring of the sheep by air and ground.

\section{Endangered Species}

Ranchers Matt and Anna Magoffin discovered 2 populations of the endangered Chiricahua Leopard Frog on their private land. When a drought in 1994 threatened to dry up the water source for the frogs, the Magoffin Family began to haul water

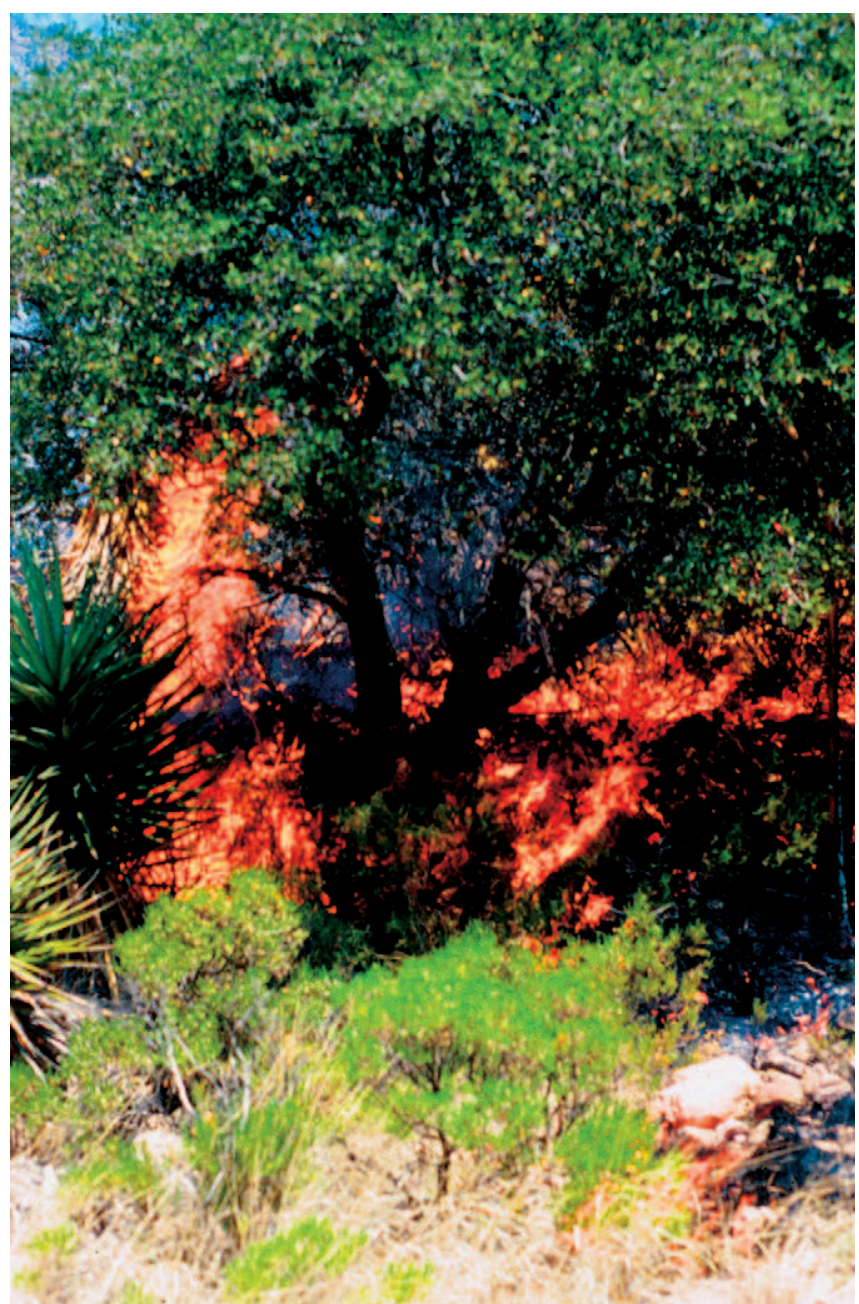

to a pond. They furnished about 1,000 gallons a week all summer, and the frogs were able to survive. The Malpai Group reimbursed the Magoffins for a portion of their expenses. This "frog project" has now grown into a major effort involving Arizona Game and Fish, US Fish and Wildlife Service, the University of Arizona, and biology classes in Douglas, Arizona. Several agency- and Malpai Borderlands Group-supported projects enabled the Magoffins to drill wells

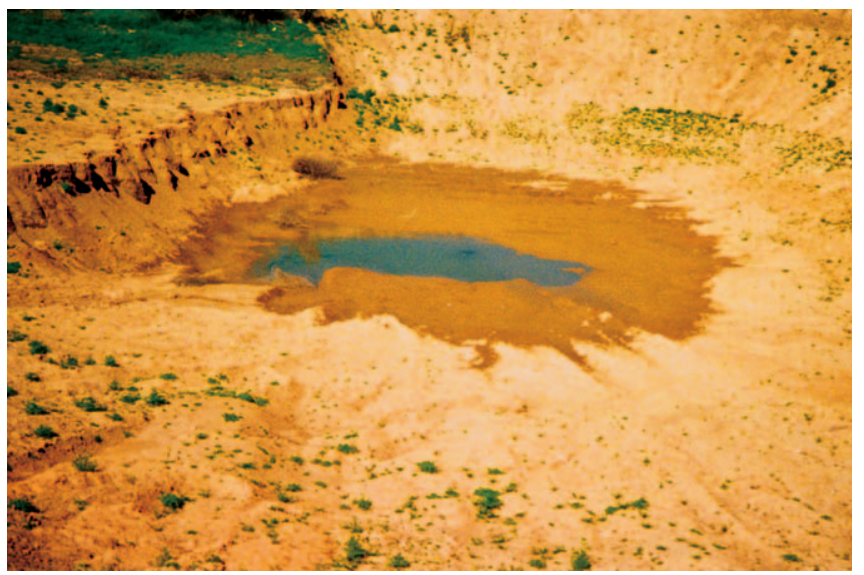




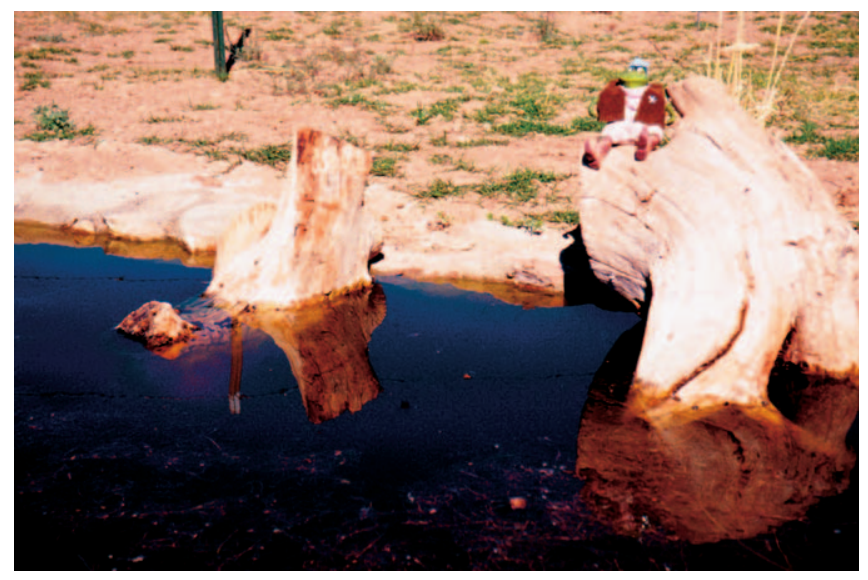

and to provide pipelines and ponds to keep the frogs prospering, while providing much-needed cattle water.

Rancher and Guide Warner Glenn encountered a very rare Mexican Jaguar while hunting mountain lions along the New Mexico-Arizona state line in March 1996. He obtained several excellent photos of this magnificent cat (the

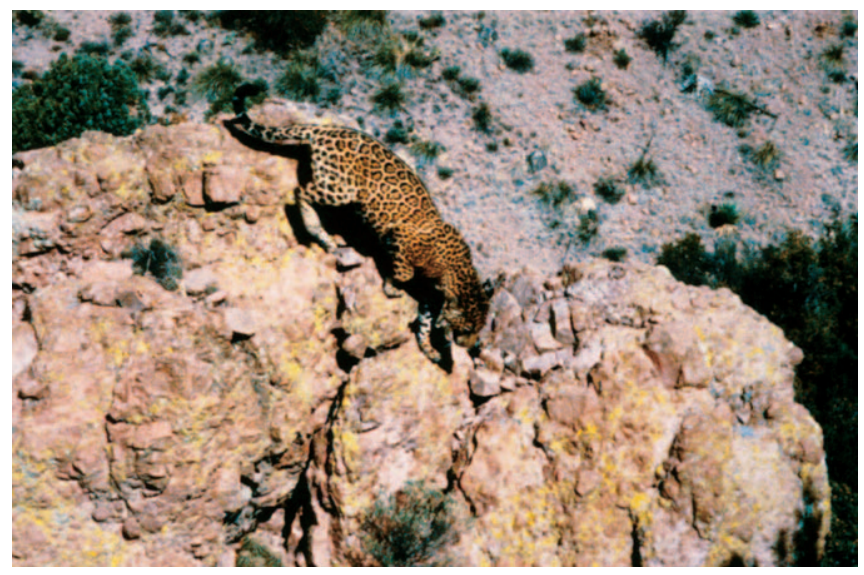

first ever taken in the United States). Warner's photos were published in the book Eyes of Fire. A portion of the proceeds from that book is placed in a fund to compensate ranchers who can document losses of livestock to jaguars and to fund jaguar research in Arizona, New Mexico, and the nearby Sierra Madre of Mexico. Efforts of the Malpai Group to encourage research and management of this animal have resulted in an active Jaguar Management team in the Borderlands region, under the leadership of Arizona Game and Fish Department.

\section{The Grassbank}

Drummond Hadley, of the Animas Foundation, originated a concept called "Grassbanking." Under this practice, ranchers with more forage than currently needed make grass available for neighbors with needs. This practice has been used to alleviate drought problems and to provide needed rest from grazing to facilitate improved range management. The

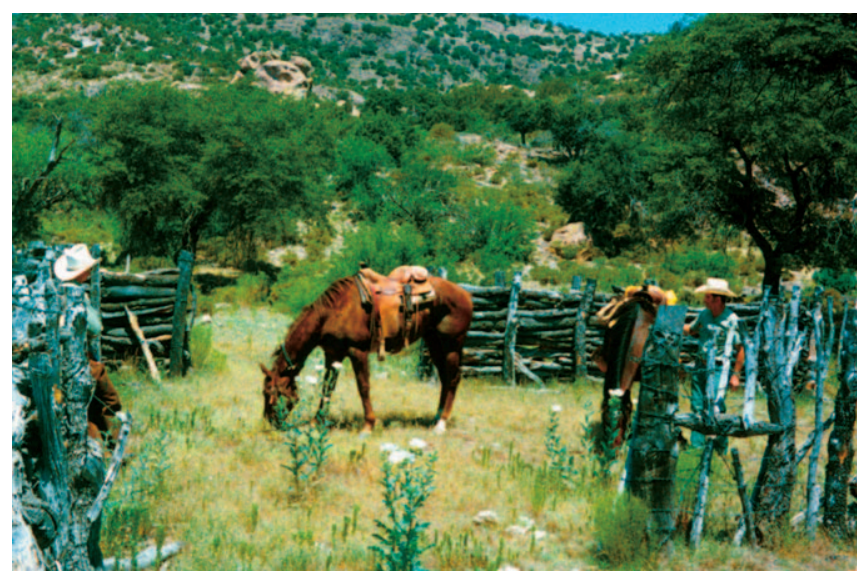

Malpai Group finds available grass and pays grazing fees to the landowner in return for conservation easements on involved private lands to promote improved range management practices. This idea is spreading throughout the West and is currently being implemented on at least one National Forest grazing allotment in New Mexico.

\section{Conservation Easements}

The Malpai Group has protected 77,000 acres of private land, affecting 204,000 additional acres of commingled state and federal land on 13 ranches, from development through the use of conservation easements. Other easements are currently in the discussion stage. The combination of these easements and the TNC easement on Gray Ranch results in considerably more than half the planning area under protection at this time.

\section{Beef Marketing}

The group is actively seeking opportunities to improve the profitability of ranching through innovative marketing strategies. They stay in touch with innovative rancher groups throughout the country. To date, no system has been discovered that fits the unique situation in the borderlands. Currently under study are such ideas as "grass-fed beef" and "organic beef." American consumers are willing to pay a premium for these specialty products, especially if they are produced in concert with significant conservation efforts.

\section{Can the MBG Be Duplicated Elsewhere?}

- Yes, but...

- Must be a local, grassroots initiative, not a government project.

- Must have dedicated agency representatives.

- Must have flexibility-every area is different.

Author is a Board Member of Malpai Borderlands Group and retired from the USDA Forest Service, PO Box 66736, Albuquerque, NM 87193, larryallen350@earthlink.net. 


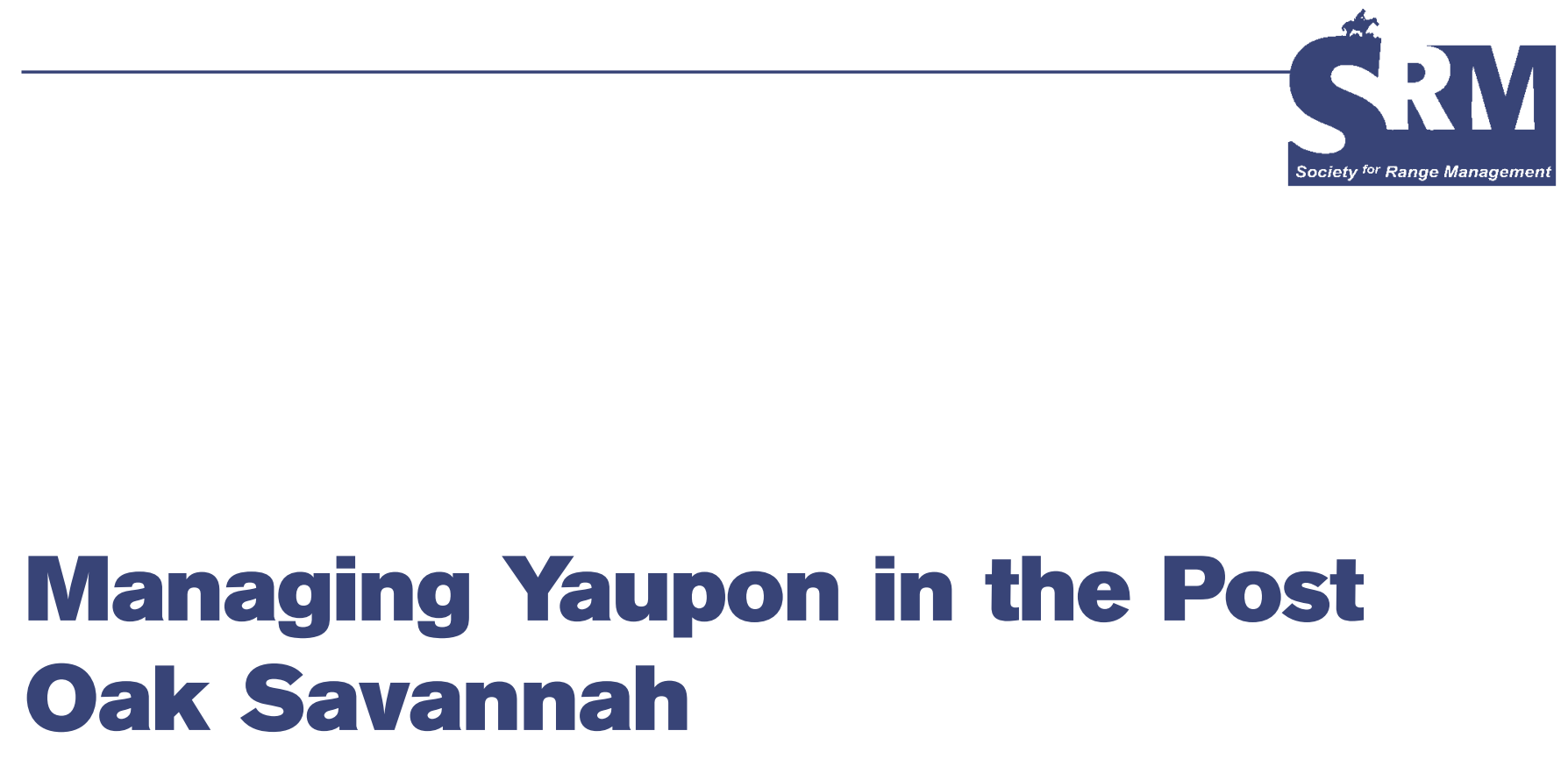

\begin{abstract}
Yaupon can be effectively managed during March or June, with individual plant treatments of triclopyr and diesel, which can be an effective tool for restoring fragmented grassland savannahs.
\end{abstract}

\title{
By James C. Cathey, Rob Mitchell, Brad Dabbert, Dale F. Prochaska, Stephanie DuPree, and Ron Sosebee
}

\section{Introduction}

Y

aupon (Ilex vomitoria) is a common understory plant in the Texas Post Oak Savannah Ecological Region. This region is a relatively long and narrow ecosystem, stretching from the Red River to San Antonio, Texas. It is bordered by the Pineywoods on the east, the Blackland Prairies on the west, and the Coastal Prairies on the south. Reports indicate that Native Americans used yaupon as a purging agent (hence its scientific name), a response to the high caffeine content and subsequent effects on the digestive system. Negative physical effects on birds and mammals are not known, but many wildlife species use yaupon leaves and berries for food and the entire plant for cover. It is a native, multistemmed, evergreen, thicket-forming shrub that sprouts from the base following top removal. ${ }^{1}$ In recent years, yaupon density has increased, and reduced or excluded other vegetation in the understory of the Post Oak Savannah (Fig. 1), reducing useable space for wildlife and livestock.

Yaupon likely gained a competitive advantage when early settlers began to suppress wildfires. Once wildfires became less prevalent, grasses and forbs declined, and woody vegetation, including yaupon, increased. Today, much of the Post

This article has been peer reviewed.

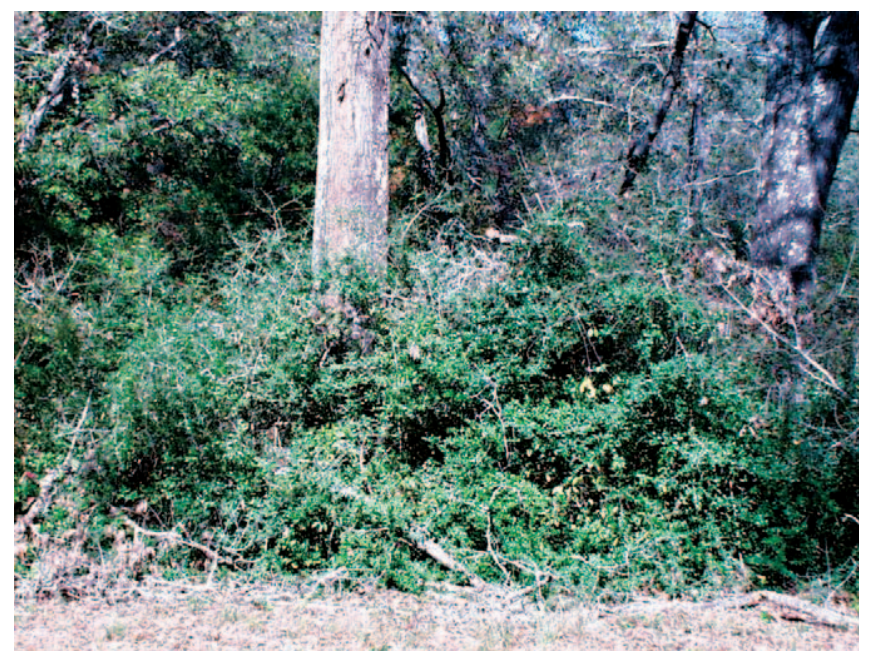

Figure 1. Dense thickets of yaupon reduce grasses and forbs, Anderson County, Texas.

Oak Savannah resembles a woodlot rather than a savannah. The strong sprouting ability of the plant has limited the long-term control of mature plants with prescribed burning or cutting (Fig. 2). Consequently, management efforts to reduce yaupon density and restore the flora and fauna of the Post Oak Savannah will require the use of herbicides, likely combined with mechanical treatments or fire. 


\begin{tabular}{|c|c|c|c|c|c|}
\hline $\begin{array}{c}\text { Garlon } 4 \\
\text { concentration } \\
(\%)\end{array}$ & $\begin{array}{c}\text { Cost/gallon of } \\
\text { solution }\end{array}$ & $\begin{array}{c}\text { Cost of solu- } \\
\text { tion/tree }\end{array}$ & $\begin{array}{c}\text { Cost to treat } \\
\text { each tree }\end{array}$ & $\begin{array}{c}\text { Treatment } \\
\text { mortality (\%) }\end{array}$ & $\begin{array}{l}\text { Cost per } \\
\text { dead tree }\end{array}$ \\
\hline 0 (Diesel only) & 2.05 & 0.04 & 0.17 & 96 & 0.18 \\
\hline 5 & 6.44 & 0.13 & 0.26 & 100 & 0.26 \\
\hline 10 & 10.84 & 0.22 & 0.35 & 96 & 0.36 \\
\hline 20 & 19.64 & 0.40 & 0.53 & 96 & 0.55 \\
\hline 25 & 24.03 & 0.49 & 0.62 & 100 & 0.62 \\
\hline
\end{tabular}

Cost estimates assume diesel costs of $\$ 2.05$ /gallon, Garlon 4 costs of $\$ 90 /$ gallon, and labor costs of $\$ 13 /$ hour. Additionally, we treated 100 trees per hour and used an average of 2.6 oz of herbicide solution/tree.

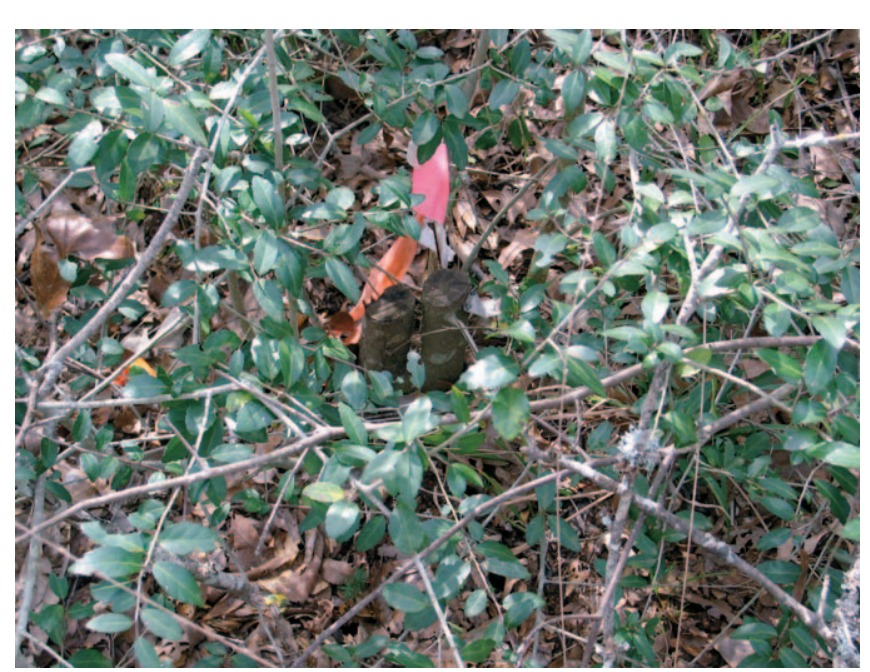

Figure 2. Top removal using the stump-cut method did not kill this yaupon control plant. Vigorous sprouting soon follows top removal.

The suggested method for managing yaupon in Texas is to apply an individual plant treatment (IPT) of $25 \%$ Remedy (triclopyr: 3,5,6-trichloro-2-pyridinyloxyacetic acid, butoxyethyl ester, 61.6\%) in diesel to the lower 12-18 inches of the trunk to wet completely around the trunk at any time during the year. ${ }^{2}$ Although this treatment has resulted in very high levels of control, little research has been conducted on other treatment options that may be more cost effective. Our objective was to develop multiple treatment options for managing yaupon to meet different management objectives and to evaluate yaupon response to treatments applied at different times of the year.

This study was conducted in 2002 and 2003 at the Gus Engeling Wildlife Management Area (WMA) in Anderson County, which is located within the Post Oak Savannah Ecological Region of Texas (Fig. 3). This property serves as a research and demonstration area and is operated by Texas Parks and Wildlife Department. Sites at Gus Engeling
WMA were selected based on accessibility and the presence of an adequate yaupon density for evaluation.

We evaluated treatment combinations of mechanical removal by cutting, basal applications of herbicides, and mechanical removal plus cut-stump applications of herbicides during March and June at Gus Engeling WMA. Twenty-five replicates (shrubs) of each treatment were applied in March (March 7, 2002) and June (June 11, 2002) in a completely random design. Herbicide treatments were IPT basal applications of $0,5,10,20$, and $25 \%$ concentrations of Garlon 4 (triclopyr: 3,5,6-trichloro-2-pyridinyloxyacetic acid, butoxyethyl ester, 61.6\%) delivered in diesel. Mechanical-plusherbicide treatments were cut only with a chainsaw, or cut and treated with $0,5,10,20$, or $25 \%$ Garlon 4 in diesel. Plants receiving the $0 \%$ herbicide were treated with diesel only. Mortality (no living tissue visible; Fig. 4) was evaluated 15 months after treatment application in June 2003 for March treatments and September 2003 for June treatments.

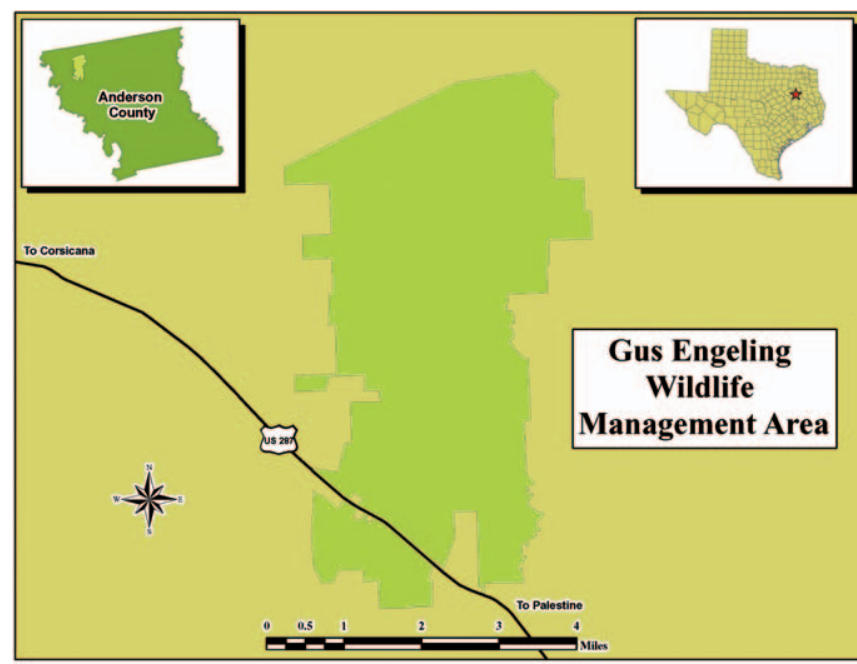

Figure 3. This study was conducted at Gus Engeling Wildlife Management Area in Anderson County, Texas. 


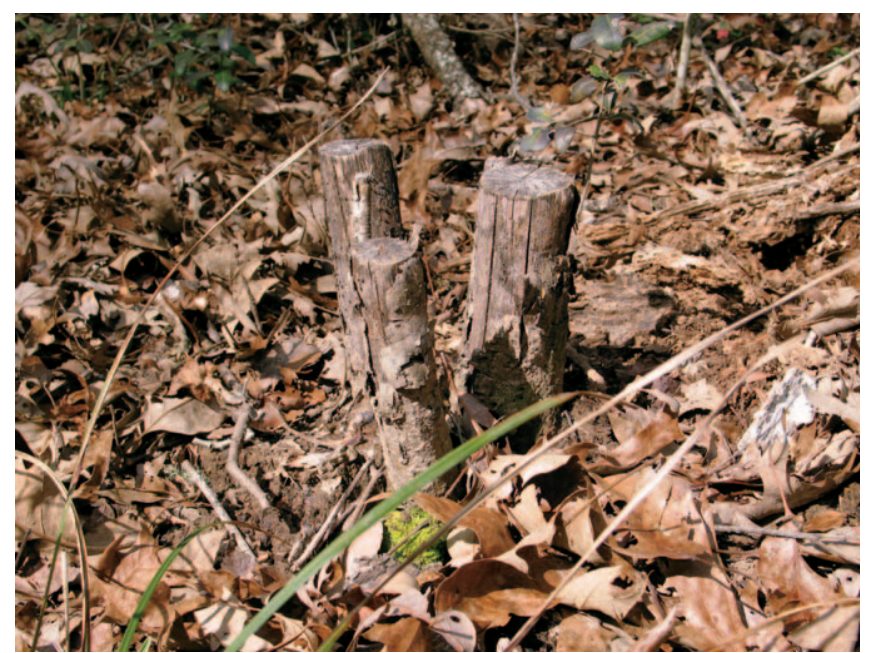

Figure 4. Stump-cut treatment combined with Garlon 4 resulted in the death of this yaupon plant.

\section{Results}

Height of the 600 treated trees averaged 10.6 feet and ranged from 2 to 24.3 feet tall. Treated trees had an average of 3.5 stems per plant and ranged from 1 to 27 stems per plant. Stem diameter of treated trees ranged from 0.1 to 3.2 inches with an average stem diameter of 1.1 inches. There was no difference $(P=0.5402)$ in yaupon mortality for treatments applied in March or June. Yaupon mortality averaged $79 \%$ for March-applied treatments and 80\% for June-applied treatments.

Treatments were different $(P<0.0001)$, and all treatments killed yaupon (Fig. 5). Mortality due to cutting (6\%) was similar to the natural mortality of nontreated trees $(2 \%)$. However, cutting followed by spraying with diesel or $5 \%$ Garlon 4 resulted in a 10\% unit increase in mortality over spraying alone. Cutting and spraying with diesel or $5 \%$ Garlon 4 resulted in $96-100 \%$ mortality. None of the spraying-only treatments achieved $100 \%$ mortality.

There was a significant treatment by season interaction $(P$ $=0.0642)$. The numerically largest difference in mortality across seasons occurred in the trees treated with a basal application of diesel (Fig. 6). Trees treated with diesel in March had a $12 \%$ unit greater mortality than those treated in June. Conversely, trees treated with 5, 10, and 25\% concentrations of Garlon 4 in June had significantly greater mortalities when compared with trees treated during March. In general, as Garlon 4 concentration increased, yaupon mortality increased.

All cut-and-spray treatment combinations resulted in at least $92 \%$ yaupon mortality, regardless of time of application (Fig. 7). The only difference in mortality across seasons was for trees that were cut and treated with diesel. Yaupon mortality was $100 \%$ for 6 of the 10 cut-and-spray treatments, with 4 treatments applied during March and 2 applied during June. The $92 \%$ mortality for trees that were cut and treated with $25 \%$ Garlon 4 likely resulted from stems being missed during spraying.

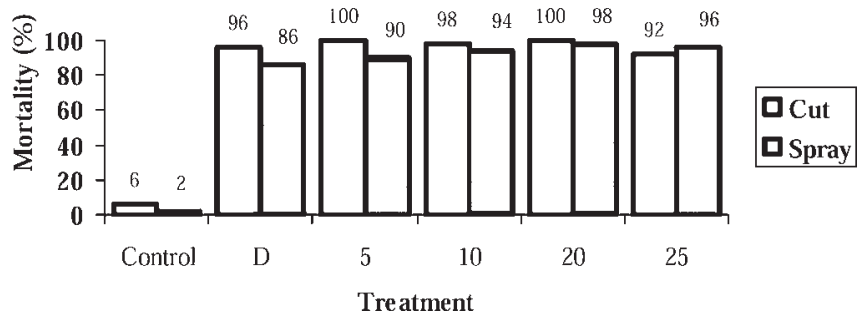

Figure 5. Treatment effects on yaupon mortality, averaged across season of application. Cut treatments represent treatments in which herbicides were applied following top removal by chainsaw. The spray treatments were applied to intact shrubs by basal applications of diesel or as $5,10,20$, or $25 \%$ concentrations of Garlon 4 . $\operatorname{LSD}(0.05)=8$.

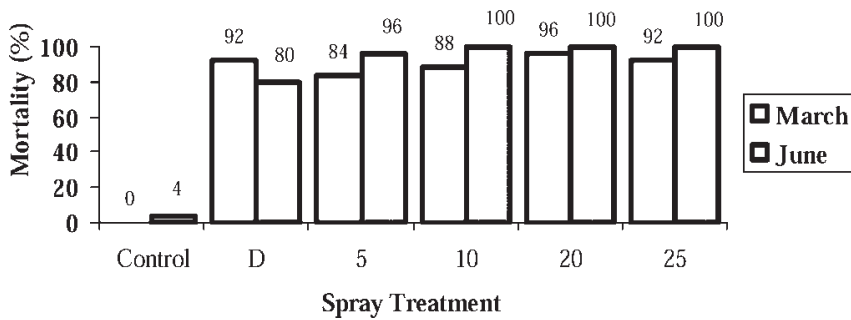

Figure 6. Treatment-by-season interaction effects on yaupon mortality. The spray treatments were applied in March and June 2002 as basal applications of diesel or as 5, 10, 20, or 25\% concentrations of Garlon 4.

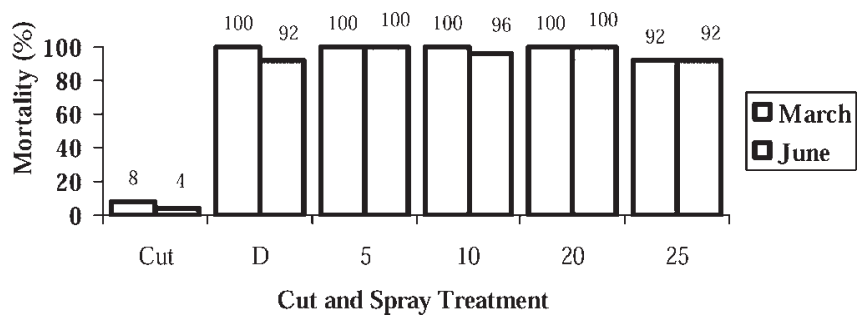

Figure 7. Treatment-by-season interaction effects on yaupon mortality. The cut-and-spray treatments were applied in March and June 2002 by removing the tree and immediately spraying the stump with diesel or with $5,10,20$, or $25 \%$ concentrations of Garlon 4.

\section{Suggested Treatments}

We suggest selecting the treatment based on your management objective. For example, if you are clearing a fence line, your goal is to kill and remove all of the yaupon. In that situation, cutting and spraying the stumps with diesel or $5 \%$ Garlon 4 usually resulted in 96-100\% mortality and would be an excellent choice. The $5 \%$ Garlon 4 treatment may add some insurance over the diesel treatment. However, if leaving standing dead trees and $80-90 \%$ mortality is an acceptable outcome, a basal application of diesel or $5 \%$ Garlon 4 would require less labor input than cutting and spraying and is much less expensive than higher herbicide concentrations (Table 1). Based on our data from treatments applied during March and June, IPT applications of 25\% concentrations of Garlon 4 were no more effective than $10 \%$ concentrations of Garlon 4 and, in some cases, no more effective than diesel 
alone. Consequently, it is not necessary to apply $25 \%$ concentrations of Garlon 4 to achieve very high yaupon control. Although we did not use Remedy as suggested by others, ${ }^{2}$ Garlon 4 has the same concentration (61.6\%) and acid equivalent (44.3\%; 4 pounds/gallon) of triclopyr.

Yaupon is a plant that can be readily controlled in most situations. We have provided several alternatives for managing yaupon, each of which could be tailored to a specific management situation and budget. However, early response to the problem is the key. Monitoring habitat and responding to yaupon invasions early will reduce the negative impacts of yaupon and make more treatment options available (ie, prescribed burning). If yaupon becomes too dense before treatment, grass production will be limited, which reduces the grazing value of the site, and wildlife habitat heterogeneity will be reduced. Additionally, increased yaupon density will restrict the ability to use prescribed burning as a management tool because of the reduced grass production on the site. When using prescribed burning as a follow-up method to IPT, grazing pressure must be monitored to ensure adequate fuel loads for burning. Early treatment will lower treatment costs because IPT costs increase as stem density increases. Additionally, early treatment will reduce the time required to return the Post Oak Savannah to productive wildlife habitat and grazing lands.

Authors are Assistant Professor and Extension Wildlife Specialist at Texas A $\Xi M$ University, Department of Wildlife and Fisheries Sciences, Rm. 210 Nagle Hall, College Station, TX 77843, jccathey@tamu.edu (Cathey); Rangeland Scientist with US Department of Agriculture-Agricultural Research Service (USDA-ARS), University of Nebraska, 344a Keim Hall, East Campus, Lincoln NE 68583 (Mitchell); Associate Professor (Dabbert), former graduate assistant (DuPree), and Professor (Sosebee), Texas Tech University, Department of Range, Wildlife, and Fisheries Management, Box 42125, Lubbock, TX 79409; and Wildlife Biologist, Texas Parks and Wildlife Department, Kerr Wildlife Management Area, 2625 FM 1340, Hunt, TX 78024 (Prochaska). This paper is a joint contribution of the USDA-ARS, Texas A\&M University, and Texas Tech University and is published as Texas Tech University Journal Series T-9-1069. Mention of trade names or commercial products in this publication is solely for the purpose of providing specific information and does not imply recommendation or endorsement by the USDA, Texas AEM University, or Texas Tech University. Always read and follow label directions.

\section{References}

1. VINES, R. A. 1960. Trees, shrubs, and woody vines of the southwest. Austin, TX: University of Texas Press. 1104 p.

2. McGinty, A., J. F. Cadenhead, W. Hamilton, W. Hanselka, D. Ueckert, and S. Whisenant. 2000. Chemical weed and brush control suggestions for rangeland. College Station, TX: Texas Agricultural Extension Service Publication B-1466. 


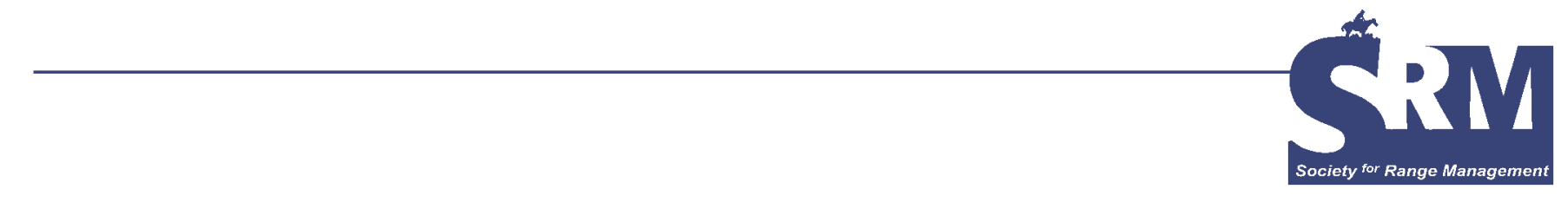

\title{
SRM Annual Meeting- Reno, Nevada
}

\author{
February 10-16, 2007
}

\section{By Staci Emm}

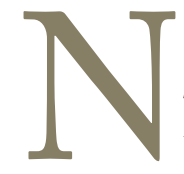

estled at the base of the majestic Sierra Nevada mountains just miles away from fabulous Lake Tahoe lies the Reno-Sparks area, which has a brilliant small-town atmosphere. This area, surrounded by chains of mountains, is better known as Reno-Tahoe: Its geography encompasses not only the mountains and the lake, but the meandering Truckee River, high desert hills, and valleys covered with both evergreen and deciduous trees. It will also be the home for the 2007 Society for Range Management meeting February 10-16, 2007.

\section{The Hotel}

The 2007 SRM meeting will be held at John Ascuaga's Nugget, which is one of the biggest convention facilities in the Reno-Tahoe area. The casino resort, with 29-story towers and one five-story building, is famous for its hospitality, great entertainment, and award-winning restaurants; it also has a great spa and pool and wireless internet access.

Along with the 85,000-square-foot casino, facilities include a large-scale arcade with carnival and video games, an indoor pool, and showrooms featuring different headline performers. There are also several dining options, including Basque and Mediterranean food, a steakhouse, Asian and Polynesian cuisine, a deli, a rotisserie buffet, and an oyster bar. The casino resort is 3 miles from downtown Reno and a 10-minute drive from Reno-Tahoe International Airport.

\section{Climate}

The Reno-Sparks-Lake Tahoe area enjoys blue skies over 80 percent of the time. The average daily highs in February are $51^{\circ} \mathrm{F}$ with average lows of $24^{\circ} \mathrm{F}$. The area enjoys a mild and dry climate with an average of about 300 sunny days a year with the snow pack accumulating in the Sierra Mountains.

\section{Skiing and Snowboarding}

You are in luck if skiing or snowboarding is your sport: Reno-Tahoe is the place to be, with Mt Rose Ski Tahoe, Diamond Peak, Alpine Meadows, Squaw Valley USA, Heavenly Lake Tahoe, Homewood Mountain Resort, Northstar at Tahoe, and Sierra of Tahoe all nearby. John

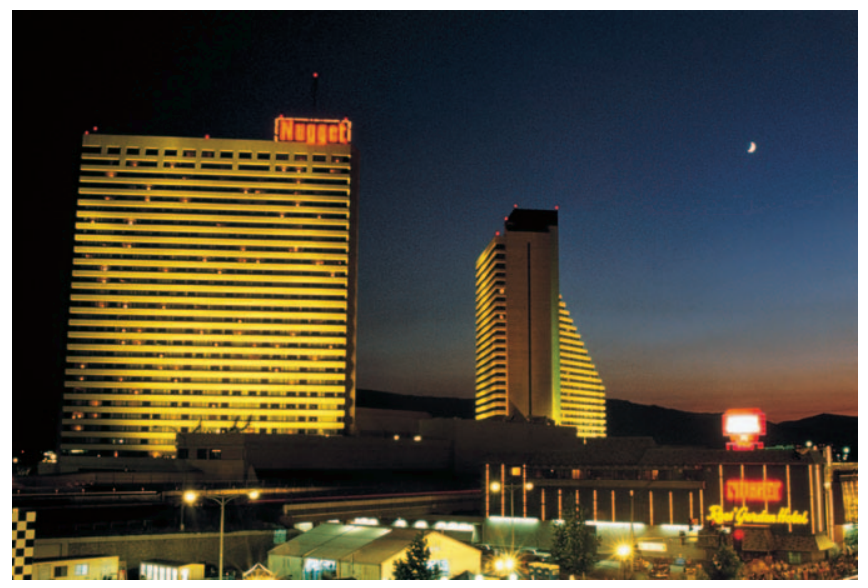




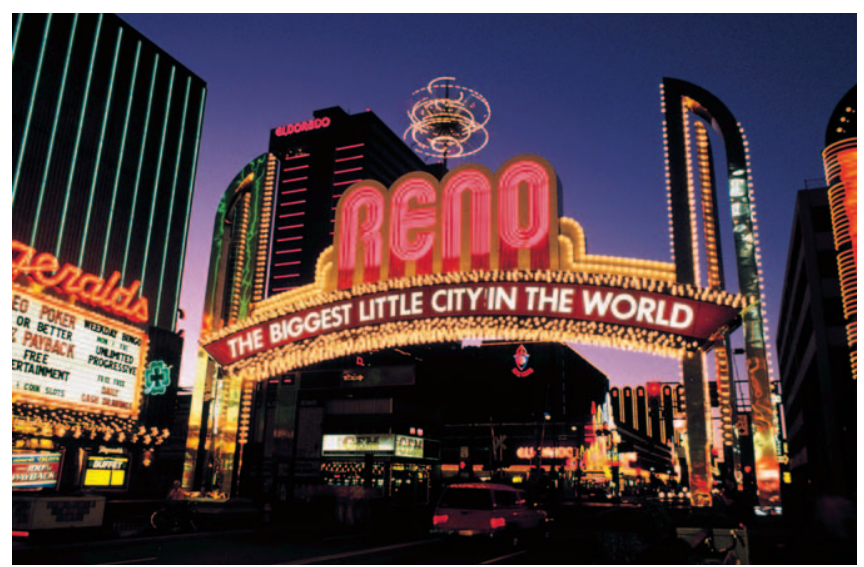

Ascuaga's Nugget has skiing and snowboarding packages allowing you to choose from any of the eight ski resorts.

\section{Reno-Tahoe International Airport}

Approximately 15,000 passengers arrive and depart daily from Reno-Tahoe International Airport in over 160 daily flights. There are 18 nonstop destinations and 20 one-stop destinations from the airport, which celebrated 75 years of service in November 2003 and is home to Alaska/Horizon, Aloha, American West/US Airways, American, Continental, Delta/Delta Connection, Frontier, Northwest, Scenic, Southwest, and United/Ted.

\section{Public Transportation}

There are several options for transportation during the 2007 SRM meeting including the city bus system, taxis, or vehicle rentals. There are several taxi services and two main shuttle systems including the airport minibus and CitiFare/CitiLift. In addition, you will have the option to rent a vehicle from any of the nine rental car agencies, which include Advantage Rent-A-Car, Alamo, Avis, Budget, Dollar Rent A Car, Enterprise, Hertz, National, and Thrifty. There will also be a shuttle from the airport to John Ascuaga's Nugget Casino Resort.

\section{Shopping}

Everywhere you look, the Reno-Tahoe area is full of different kinds of shopping adventures. There are shops at the casino resort and a large modern mall 15 minutes away from

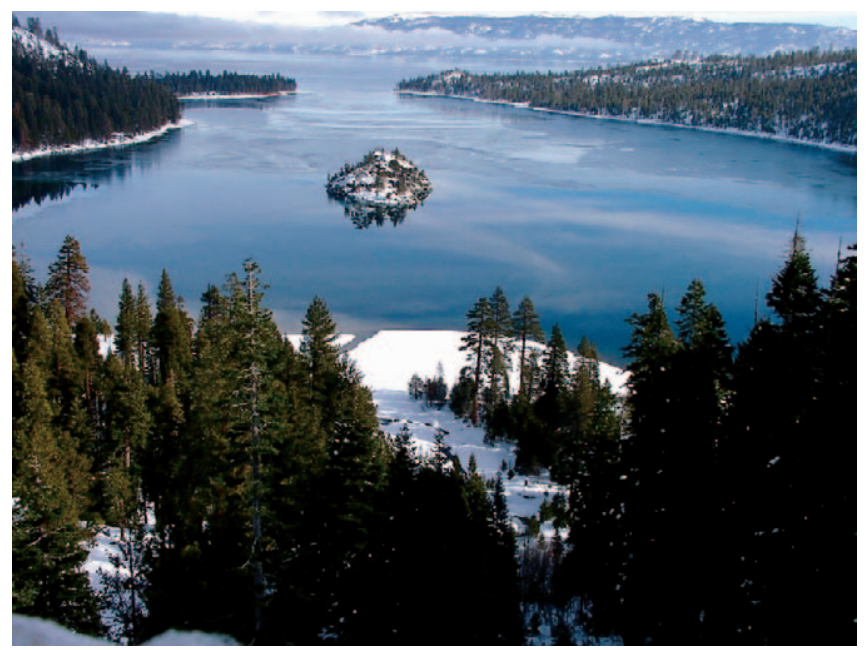

John Ascuaga's Nugget. There are also several small specialty shops located throughout the area in small mini-malls. Reno-Tahoe offers a variety of specialty shops along with the major department stores. Shopping in the area is sure to keep folks busy for days at a time.

\section{Overall Thought and Reminders}

Whatever you need in the way of four-star restaurants, skiing, fishing, or other recreation, the Reno-Tahoe area is the place to be. So gear up and prepare to attend the 2007 SRM meeting scheduled February 10-16, 2007, in order to enjoy the ultimate SRM experience.

The 2007 SRM meeting will provide an excellent opportunity to continue your education and strengthen your expertise with technical sessions, posters, workshops, and symposia. There will also be tours to one of Nevada's wild horse facilities and other field activities. There will be many opportunities to network and socialize with rangeland professionals. The agenda is still being prepared, but the excitement is building and the 2007 SRM planning committee is working diligently to make your experience enjoyable.

Author is Extension Educator, University of Nevada Cooperative Extension, Hawthorne, NV 89415, emms@unce.unr.edu. 


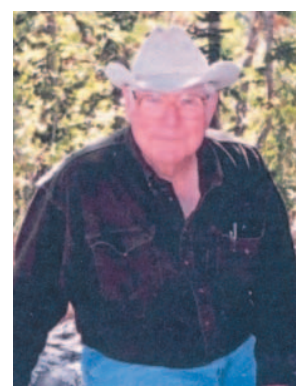

Thad Box

\section{On Fossils, Buffaloburgers and Sustainable Ecosystems}

The rat squirrel found on a meat hook in Laos and widely touted as a new mammal species isn't new after all. According to an article in Science it was first described from an 11-millionyear-old fossil record found in China.

This spring a group of Australian and Indonesian scientists visited a remote mountain in Indonesia previously seen only by local tribes. They found a new species of bird, some 30 new species of butterflies, and many mammals that had not been seen in the wild for several decades.

Species of tree kangaroos, listed as rare and endangered elsewhere, were numerous. Animals showed no fear of humans, many allowing the researchers to simply pick them up and examine them.

New Zealand had only one mammal, a bat, when the first Polynesians arrived. Birds, many of them flightless, had evolved into the niches occupied by mammals on other land masses. Humans, rats, dogs, and swine arrived with the first boats. They soon destroyed many species that had evolved without predators.

Then Europeans arrived with their large ungulates, cows and sheep. They brought deer for sport and imported elk from America. Possums were introduced from Australia. Native grassland, forests, and heath were changed as the native plants were grazed out or deliberately destroyed and replaced by imported forage species.

The deer, elk and possum populations increased to plague proportions. Large natural areas were defoliated; many forests turned into wastelands. The Department of Conservation began a long and costly battle against the herbivores. Gunners from helicopters killed thousands of deer and elk, bringing their populations in most places under control. The abundant supply of slaughtered deer developed a market for venison.

As the herds were reduced to carrying capacity, farmers started deer farms. Today, deer and elk farms are common. Most were started by animals captured from the wild herds of imported, nonnative wildlife. But today, by almost any measure, they are domestic animals.

The theme of this issue of Rangelands is "Wildlife." This theme raises 2 questions for rangeland stewards: What is wildlife? And how does wildlife fit into the role of sustainability of rangelands? These questions are complicated both by the biological roles of the animals and by political interpretation of the beast in our culture.

When I first became a range management professional, wildlife was generally considered as game animals and furbearers. If it provided sport hunting or an economic gain we claimed it. Then we added another category of nongame wildlife to include hummingbirds, songbirds, and cute little chipmunks - those things that gave people pleasure just because they existed. To separate them from bothersome rats, starlings, and things that annoyed us, we coined the term pest wildlife.

Then rare and endangered species, those animals that were in danger of extinction, became key animals in our land use plans. It took special laws and court rulings to make those ani- 
mals part of our working thoughts when managing rangelands. We were forced to look at the entire biota affecting rangeland use, not just those important in the marketplace.

Our rangeland focus has gradually changed from shortterm economic gain to long-term sustainability. We realize we must be concerned with all animals' roles in the functioning of the ecosystem. Animals from dung beetles to elephants must be factored into the health of the land. We are still confused. It may seem logical to consider any species that reproduces and sustains a population in a habitat without human husbandry as wildlife.

Biological purists say the animal has to be native to the site, and argue for complete restoration of the site-soil, plants, and related animals-so the species can continue. Ecological pragmatists, more concerned with ecosystem function than with "first rights," may readily accept an exotic species as wildlife as long as it contributes positively to energy flow, nutrient cycling, and system stability.

While we biologically oriented stewards wrestle with ecosystem function, political response to nonnative species is as confusing as the biology. Ring-necked pheasants, introduced game birds, are widely accepted as wildlife. Feral swine are considered wild boar, hence wildlife, in some places and pests to be destroyed in others.

We do not even agree on what constitutes feral animals. To some, any nonnative population is feral. This can include domestic livestock under management or starlings in our cities. To others, feral means an unmanaged domestic animal gone wild.

Free-ranging horses and donkeys are some of the most successful feral species on rangelands. A court case decided they are not wildlife. Another law protects them on some public lands, limiting what can be done to keep them in balance with their habitat.

When primary concern is for system sustainability, it may not be all that important to try to determine what is wildlife, what is native, what was there originally, or what is a domestic animal. The important question is whether the system, not the individual species, functions in a way that can sustain itself.
As our knowledge of succession evolved from the Clementsian paradigm to one that recognizes alternative stable states, we realized that thresholds are reached where systems themselves change. The old system morphs into something quite different, but often stable and perhaps sustainable.

The new system develops its own interrelationships and balances. To try to make it support original "wildlife" is no longer simply providing some past habitat that has been altered from misuse. Practically, original wildlife is now an alien, trying to find conditions that no longer exist in the new system. If sustainability is our goal, restoring original wildlife may not be the best path to take. We have to address what is needed for the new system to function most efficiently.

On a drive through desert rangelands between Las Cruces and Almagordo, New Mexico, one is more likely to see an oryx than a deer or pronghorn.

On the checkerboard ranges of southern Wyoming, huge, beautiful, "wild" draft horses, descended from Belgian work animals, graze forage once eaten by elk.

Large German brown trout lie waiting a fly in the streams of my valley; Rio Grande turkeys roost in the trees overhead.

In the rocky cheatgrass ranges of southeastern Idaho, chukar partridges flourish.

Wolves, giant condors, lynx, and other animals once extirpated from western ranges are being released; some reestablish themselves.

Steaks from bison raised on American ranches and venison from New Zealand farms join beef and lamb on menus of the world's finest restaurants. Buffaloburger is sold in my grocery store.

The real question about wildlife may not be which of these critters "belong" on our rangelands, but which can help our communities become sustainable. In the quest for sustainability, we still have to listen to the land.

ThadBox,thadbox@comcast.net. 


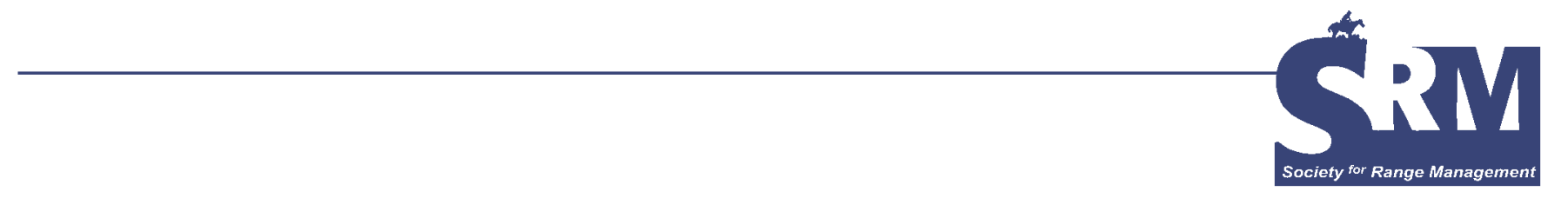

\section{Thirteenth in a Series: Insight From SRM's Charter Members}

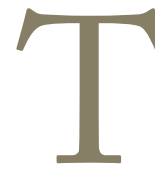

he SRM History Committee has conducted interviews with many of the Society's Charter Members to capture their perspective of events leading to and subsequent to the formation of the American Society of Range Management in 1947-1948. Interviews from several of these individuals will be shared for today's SRM members to enjoy and learn from.

\section{SRM Charter Member - W. E. Howard \\ Editor's Note: Dr. Walter E. (Howdy) Howard, long-time University of California, Davis, faculty member, sent his written statement for the record. Howdy's home address is 24 College Park, Davis, CA 95616 (wehoward@ucdavis.edu, tel: 530-756- 1509). His office address is Wildlife, Fish and Conservation Biology, University of California, Davis, CA 95616 (tel: 530- 752-2564), where he still spends each morning.}

My name is Walter E. (Howdy) Howard. I was born April 9, 1917. My field of interest has always been to find better ecological ways people and wildlife can cohabit with human-wildlife conflicts. I no longer do research but write books. Last year it was Saved by Bed Bugs, a frank autobiography with 278 colored pictures. In January 2006, Nature Needs Us will come out. It is an in-depth analysis of the reasons why nature needs our help in human-altered environments. I am currently editing a second edition of Nature Needs $U s$, even though the first copy will not be out until January 2006. I am also writing about my World War II experiences as a ski trooper invading Kiska Island.

I received my $\mathrm{AB}$ (1939) from the University of California at Berkeley and both my MS (1942) and PhD (1947) from the University of Michigan. When I joined the faculty of UC Davis in 1947 it was called the Division of Agricultural Zoology at the University Farm. I was hired to research rodent and other wildlife problems of rangelands.
For the first 2 years I was stationed at the US Forest Service, Forest and Range Experiment Station, San Joaquin Experimental Range (SJER) at O'Neals, California. My initial research projects were studying the life history and biology of pocket gophers and, with Ken Wagnon and Jay Bentley, the degree to which ground squirrels competed with heifers for spring forage.

Being stationed at the SJER in 1947, I enthusiastically joined Harold Biswell, Jay Bentley, M. W. Talbot, and others as a charter member of the Range Management Society.

With cooperation from R. L. Fenner and graduate student Hank Childs, we made a very significant discovery at SJER concerning wildlife survival of range fires. We showed that most mammals and other animals had evolved a way of surviving fires, and that the main mortality factor was from loss of oxygen, not heat. We demonstrated that if a mammal, located on the ground surface, was covered so as to protect it from heat, that even though fire had eliminated the oxygen, the animal could obtain all the oxygen it needed from the soil. This led to firefighters carrying a tarp so they could survive the lack of oxygen when a firestorm passed over them.

I participated at the beginning of brush burning activities, when the goal was to convert millions of acres of California chaparral into grasslands. An early plan was to broadcast the seeds as soon as possible in order to use the ash as a seedbed. In cooperation with Milt Miller we showed how the ash blew away and that the fire did not kill the harvester ants and rodents, which would then eat the seeds. For a while we dyed the seeds yellow to protect them from birds and treated the seeds with a rodenticide to protect them from ants and rodents. However, it was soon realized that the best solution was to drill the seeds.

Another finding with brush burning was that wildlife had a high ability to survive fires. They have evolved the neces- 
sary escape routes, especially by entering open burrows. We found that it is actually unusual for a deer, rabbit, or bird to be killed by either a controlled fire or wildfire.

In cooperation with Ken Wagnon and Jay Bentley at SJER we measured the degree to which ground squirrels competed with heifers for spring forage, and hence the need for squirrel control. After developing a live trap for pocket gophers, with assistance from graduate students, I made the first life-history investigation of pocket gophers. This was at the SJER. This study led to the development of the original burrow builder for controlling pocket gophers. Robert Kepner at UC Davis designed it. I took this design to Denver, Colorado, and gave it to the US Department of Interior's Animal Damage Control group, which then was in the US Fish and Wildlife Service, so they could build one to test in their area.

My memory of the first ASRM Meeting in Salt Lake City is that I had to take an overnight train to get there. Since the glands in both of my armpits were swollen, my doctor gave me a note of instructions for the train conductor that I was to hang around my neck in case I came down with plague. I had been handling California ground squirrels, which can carry plague. Fortunately, I survived.

I used the membership list and first meeting of the California Section of SRM to form the California Section of The Wildlife Society.

Rangelands offer an exciting and rewarding field for researchers. I sure miss my personal involvement in rangeland research and strongly urge young people to participate in rangeland activities.

SRM Charter Member - Dr. Roald A. Peterson Editor's Note: Dr. Roald A. Peterson, 90, of Fayetteville, Arkansas, passed away Friday, January 9, 2004, in Fayetteville, of pneumonia. He was born March 31, 1913, in Watford City, North Dakota, to Sigvart and Elena (Carlsen) Peterson. The following obituary was printed in the Northwest Arkansas Times.

Roald A. Peterson was the ninth of 11 children, 2 born to his parents in Norway before they immigrated and homesteaded on a large farm in North Dakota. Both his Norwegian heritage and being raised on a cattle farm had a profound influence on him. He was 2 months and 22 days away from his 91 st birthday.

Dr Peterson was an Adjunct Professor of Agronomy at the University of Arkansas, a member of the Society for Range Management, Sigma XI, The Scientific Research Society, the Unitarian Universalist Fellowship in Fayetteville, and Partners for the Americas.

He received both his Bachelors and Masters degrees in botany from the University of North Dakota, Fargo, North Dakota, and his $\mathrm{PhD}$ in plant ecology from the University of Minnesota, Minneapolis, Minnesota.

He is survived by 2 daughters, Hannah S. Waite, son-inlaw Dr Thomas W. Waite of Chaska, Minnesota, and Rima S. Peterson of Fayetteville, Arkansas; two sisters, Ruby
Howard of Cottonwood, Arizona, and Alice Hawley of Kemah, Texas; one granddaughter, Sarah Morse of Chaska, Minnesota; and many nephews and nieces throughout the United States, Puerto Rico, Germany and Spain as well as extended family members in Norway. He was preceded in death by his beloved wife of over 40 years, Carmen, daughter Andrea and son Malcolm.

During his extensive and rich career, after the United States had entered the war, he served training World War II pilots in ground flight instruction and meteorology at the then-Army Air Force base near Fort Worth, Texas.

In the 1930s and early 1940s, he was an early pioneer in integrating cooperative work, empowering both poor blacks and whites who worked lands they did not own throughout the South, as well as encouraging and helping farmers in the North to form cooperatives that gave them both economic and political power and clout unheard of until those days.

He worked for the US Department of Agriculture in both range management and forestry, primarily in Montana.

A little known aspect of his wonderful but often difficult life, was that after nearly a decade of being hounded by the House Un-American Activities Committee, and cleared before every tribunal he was brought before, he was ultimately blacklisted by the infamous Joe McCarthy, Roy Cohn and J. Edgar Hoover group of legal thugs on the word of one man, the only person, among many who testified in Washington on his behalf, friends and colleagues who knew him as an extraordinary human being, were intimately familiar with his often ground-breaking and vital work, not to testify in his favor. To his great credit, he never held it against this individual, understanding that intimidation and fear ruled the testimony of so many during those dark days of our history.

Though this ended his work in the United States, after attaining so much international acknowledgment and recognition of his outstanding work on almost every continent of the planet, J. Edgar Hoover was forced by then-President John F. Kennedy to write him a letter of apology and an invitation to return to work in the United States. He did not do so until his retirement in 1979.

The blacklisting turned out to be a blessing in disguise, as he and his family left the country and in 1953 he was appointed Director of Agriculture of the Southern Zone of the Organization of American States in South America. His area of work comprised the countries of Uruguay, where he lived and OAS headquarters were located, Argentina, Brazil, Paraguay and Chile.

It was here that he met, fell in love with and in 1956 married the Puerto Rican beauty, Carmen S. Sanchez, who held the same directorship in the same countries, in what was then known as home economics.

He had been a single father, with a nanny, for 6 years, to his 3 children, since the loss of his first wife, Lillian Alexander, during the devastation caused by the fallout of the HUAC investigations. 
Dr. Peterson's career in South America was filled with joys, travels and work: with men and women of each country, training them in the science and practical applications of agronomy, range management, animal husbandry, land care, etc., to maximize good land use, better yields, nutrition, healthy cattle and food production. Both he and Carmen received many awards of recognition for their contributions from Heads of State, Secretaries of the Interior, Ministries of Agriculture, as well as national and international organizations too numerous to mention.

After a work trip and international congress in Australia and New Zealand, Dr Peterson was nominated to head a division of the Food and Agricultural Organization of the United Nations, headquartered in Rome, Italy. He accepted the position and the family moved to Rome in 1961, from where he worked and traveled until his last appointment in the Dominican Republic.

It was shortly after this nomination to serve in the FAO that he was invited by Queen Elizabeth and Prince Phillip to receive honors, as well as by the King and Queen of Norway, when he and Carmen took advantage of being there, to look to and visit the extended family, including siblings of parents, whom he got to talk to by telephone and thus to reestablish connections that had been long lost.

During those years, he did what was probably the most impacting and extensive work of his life.

He was the first foreigner to be invited, by the thenSoviet government, to come to the USSR and go to Outer Mongolia, working and living with tribal people there, on the problem of milk conservation and preservation. Even on his deathbed he commented how he had learned so much in Mongolia, not only from the people, but about them, by watching their horses. It was one of the highlights of his many work-related travels, which he spoke frequently about, and which, as an avid horseman, had especially enjoyed their small, but very fast, adept horses.

His work with FAO took him to every country in Africa, where he trained and worked with teams, which hopefully today are still able to carry on his legacy. He lived in the bush country, with Pygmy, Zulu and many other tribal peoples and thoroughly enjoyed it, enriching our lives with stories, photographs and artifacts particular to each tribe, still dear to him after all these years.

He traveled and lived and worked with nomadic tribes as well as government officials and his teams, in what was then Persia, in Egypt, Lebanon, Israel, Morocco and all over India, always bringing home stories and artifacts handmade in those regions, igniting his family's interest and curiosity to visit and travel to them themselves.

Dr Peterson retired in 1979 and moved with his family to Fayetteville, Arkansas. He chose Northwest Arkansas as his final home for its peacefulness, scenic beauty and opportunities to do agricultural research through the University of Arkansas. Due to his experience and continued contributions to the field, he was named an Adjunct Professor of Agronomy. He was one of the Arkansas-East Bolivia Partners of the Americas, and did short-term consultations in both Bolivia and Sierra Leone. He was also a dedicated member of the Unitarian Universalist Fellowship of Fayetteville, where he served as president for several years.

The epitome of the green thumb, he was a passionate gardener of both vegetables and flowers throughout his life. He was well known for his bountiful tomato crops. During his retirement he grew and did research on several lesserknown legumes and vegetables, including the pigeon pea, chayote, kohlrabi, and the Jerusalem artichoke. Always an avid reader, he enthusiastically participated in the Great ideas and Soul Searchers discussion group at Butterfield Trail Village.

Tom Bedell is a member and former chairman of the SRM History Committee and a member of the Pacific Northwest Section living in Philomath, Oregon, tbedell@peak.org. 


\section{Setters to the Editor}

Dear Gary,

I was pleased to read "Guts and Grasses" by Ned Snyder. It is interesting that he is a non-traditional rangeland researcher. This is the first article I can remember that gave some credit to Allan Savory's Holistic Management principles, processes, and practices.

Also interesting to me is the Holechek paper, “Grazing Impacts on Rangeland Vegetation: What We Have Learned.” They mention how much has been learned in the last 20 years. Where have they been?

Savory understood and taught the impacts of livestock grazing and the negative effects of long-term exclusion and set stocking in brittle environments 30 years ago!

Many of the ranch operators I have read about, that receive awards for excellent stewardship, have been exposed to and practice Holistic Management.

I am a long-time member of SRM in California and I am also a Holistic Management Certified Educator. I met Allan Savory in 1978 when we both spoke at Dr Ensminger's Stockmans' School. (After 2 days all sessions closed and all attended Savory's presentation.)

I attended several of Savory's schools, realized that what he taught fit my experience and observations, and started teaching Holistic Management in my Extension Workshops.

I did receive the Rangeland Manager Award from the California Section of SRM, partly for conducting these workshops, but could not convince the SRM leaders to consider Savory as a source of valuable information.

At that time UC Berkeley researchers (Heady et al) were studying vegetation response to simulated grazing by clipping small plots and adding straw for residual dry matter. They concluded that residual dry matter and weather pattern determined species composition and that grazing management had little effect. They had randomized and replicated plots, but the treatments were artificial and did not reflect reality.

There! I got that off my chest. I now do international livestock consulting and find Holistic Management principles, processes, and practices are very appropriate, useful, and accepted in the developing countries as well as in the United States.

Best regards,

Monte Bell

UC Cooperative Extension, Emeritus

Holistic Management Certified Educator

International Livestock Consultant

mbel195963@yahoo.com 


\section{SRM Section News}

\section{SRM Wildlife Habitat Committee 2005-2006 Annual Report}

SRM's Wildlife Habitat Committee (WHC) is composed of individuals dedicated to improving our understanding of the science and management of rangeland wildlife and their habitat. Our major functions are to provide information to SRM and others on wildlife ecology and management, foster relationships between SRM and other wildlife groups, and to provide input on pending legislation that may affect rangeland wildlife. The WHC meets each year at the SRM Annual Meeting, and membership is open to all SRM members who attend or contact the committee chair. This report highlights some of the contributions we have made over the past year.

The WHC was instrumental in working with 5 other professional societies to develop the Scientific Societies' Statement on the Endangered Species Act. Because of Congressional scrutiny of the Endangered Species Act (ESA) of 1973, SRM joined the American Fisheries Society, the Ecological Society of America, the Entomological Society of America, the Society for Conservation Biology, and The Wildlife Society in an effort to produce a joint statement on science-related issues in the ESA reauthorization. Our common goal was to improve the science and effectiveness of recovering rare and declining species and their habitats. We focused solely on the issues that we thought our expertise as scientists and experience in helping to implement the ESA was most relevant. Throughout the effort, we maintained a focus on the science-related issues in order to preserve the scientific integrity of our societies and thereby increase the credibility of our statement. With the approval of the Board of Directors, SRM became an official signatory of the joint statement in February 2006. The statement was developed after the US House of Representatives passed its version of the ESA reauthorization (H.R. 3824, The Threatened and Endangered Species Recovery Act).
However, we were able to provide our statement to the US Senate before it considered the issue.

The WHC regularly develops special symposia for SRM Meetings to explore important rangeland wildlife topics. Three symposia were developed and presented at the SRM Annual Meeting in Vancouver, British Columbia. These half-day sessions covered the following topics: 1) Wildlife Habitat Analysis of the Future: Examining Multiple Scales using Geospatial Technology, 2) Application of the Collaborative Resources Stewardship Process, and 3) Grazing, Riparian, ColdWater Fish: Is Beneficial Coexistence Possible? We plan on organizing special symposia for the Annual Meeting in Reno, Nevada, and welcome your participation.

Throughout the year, the WHC is asked to review and comment on a wide variety of efforts and publications. Some of the issues we provided input on included the Sustainable Rangelands Roundtable Charter and Core Indicators, a Canadian proposal to develop best management practices for at-risk species, and revisions to the SRM Position, Policy, and Resolution Statements. We publish committee business updates, along with articles on emerging wildlife habitat issues, in our regular newsletters. Three newsletters were produced and distributed over the past year. Newsletters can be found on-line at the SRM home page (www.rangelands.org) by navigating to the Wildlife Habitat Committee page.

The WHC Officers for 2006 are Roy Roath (Chair), Ted Toombs (Chair-Elect), and Lance Vermeire (Communications Director). Steve Peterson was selected as Chair for 2008. A special thanks to the members of the WHC for their commitment and hard work in 2005.

Prepared by Jeremy Maestas (2005 Chair); Jeremy.maestas@ ut.usda.gov. 


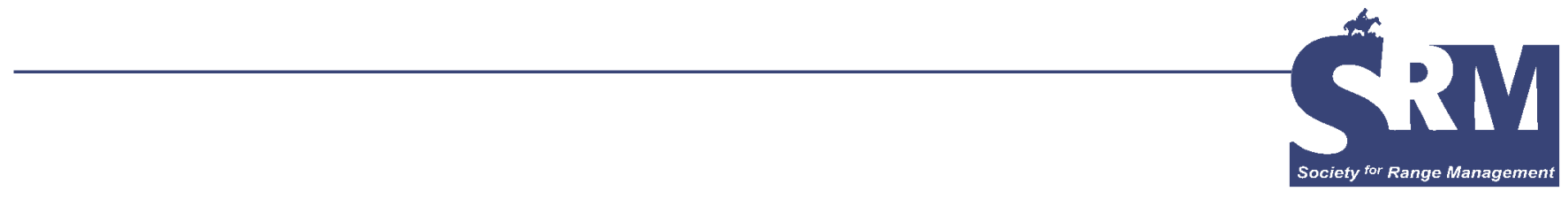

\section{SRM Honor Awards}

\section{Presented at the Society's 59th Annual Meeting in Vancouver, British Columbia, on February 15, 2006.}

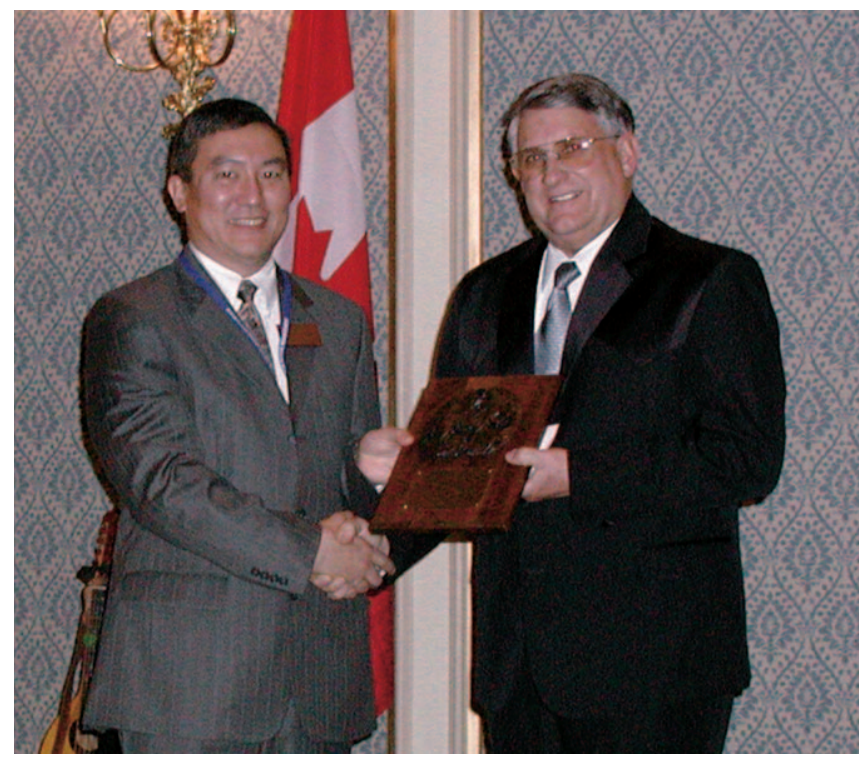

John Tanaka and Gary Frasier

The Fredric G. Renner Award is the highest bestowed by the Society for Range Management. The award is named for one of the SRM's founding fathers, who served as its 2 nd President.

The Society for Range Management's most prestigious award, the Fredrick G. Renner Award, is presented this year to Gary W. Frasier.

Gary qualifies for this recognition because of the outstanding contributions he has made to the Society through his 20-plus years of service as editor of Rangelands and the Journal of Range Management and because of the many con- tributions he has made in his 42 years of rangeland research as a scientist working for the Agricultural Research Service (ARS). Much of this work was conducted on rangelands of Arizona and Colorado.

Because of his editorial work, Rangelands and the Journal of Range Management-now known as Rangeland Ecology \& Management-have become very informative and highly respected publications. The quality of the articles in both publications improved under Gary's leadership, as did the presentation quality of the materials in these articles. Gary has sought out authors from inside and outside the Society to write synthesis articles that have become benchmarks of our profession. Because these publications are the most visible aspect of the Society, Gary has-as much or more than any other individual-ensured that $\mathrm{SRM}$ is recognized as a valuable and respected professional organization. Gary has not limited his editorial contributions to SRM publications; he has also served on the editorial board for the Journal of Plant Interactions (Taylor \& Francis, UK, publisher).

Gary's research career with ARS encompassed 3 major areas: 1) water supply (water harvesting), 2) rangeland revegetation (water requirements for plant establishment), and 3) rangeland surface water hydrology (runoff and infiltration). Gary's research represents a body of quality work. He has authored or coauthored over 120 technical publications-67 as senior or sole author, including over 20 in the Journal of Range Management. Several of his publications are considered to establish the state-of-the-art for rangeland hydrology and water supplies on arid rangelands. Gary is also very 
well respected for his willingness and ability to engage in interdisciplinary research efforts with other scientists.

In addition to his work with ARS, Gary has been an affiliated faculty member of the Forest, Rangeland, and Watershed Stewardship Department at Colorado State University. His interdisciplinary approach has made him a particularly valuable advisor of graduate students. He has served as research advisor or coadvisor for $10 \mathrm{MS}$ and $4 \mathrm{PhD}$ students and project leader for 2 US Department of Agriculture (USDA)-funded research projects to investigate the impacts of cattle grazing on infiltration, runoff, and erosion in riparian ecosystems. He is currently coproject leader in a joint ARS and Colorado State University (CSU) longterm study to determine the impact of soil loss on vegetative, hydrologic, and soil resources and the long-term sustainability of shortgrass steppe and cold desert sagebrush ecosystems.

For his lifetime of commitment to the Society and to rangelands, the Society for Range Management is proud to present Gary W. Frasier with the Frederic G. Renner Award.

The W. R. Chapline Research Award was established in 1986 to provide recognition to members of SRM for exceptional research accomplishments in range science and related disciplines.

Dr Gerald (Jerry) E. Schuman is recognized as the leading international authority on mined-land reclamation and carbon sequestration in rangelands. His research contributions in assessing soil responses to land management practices in semiarid and arid rangeland ecosystems, which have addressed customer-relevant problems, are unparalleled.

Jerry's professional contributions to the field of range management include mentoring 34 graduate students, publishing more than 175 scientific articles, and accepting numerous leadership positions.

He has continually provided high-quality, practical research for the land manager, addressing contemporary issues while concurrently advancing the state of knowledge in soil carbon and nitrogen cycling. Jerry's research addressed key customer issues at regional, national, and international levels and has had significant impact on public policy. This focus on customer issues is quite evident because the majority of his research has been productive and cooperative projects with the private sector (eg, coal mining companies, individual land owners), so that his research is often used for demonstration purposes by organizations and local, state, regional, and national agencies.

Jerry's research into land rehabilitation has led to the development and acceptance of technology that is used by the mining industry throughout the United States and in many other countries.

Jerry's cutting-edge research on the development of soil quality and rangeland health parameters and indicators and on the evaluation of land management practices that enhance carbon sequestration in rangeland ecosystems represents a major breakthrough in the transfer of technology to

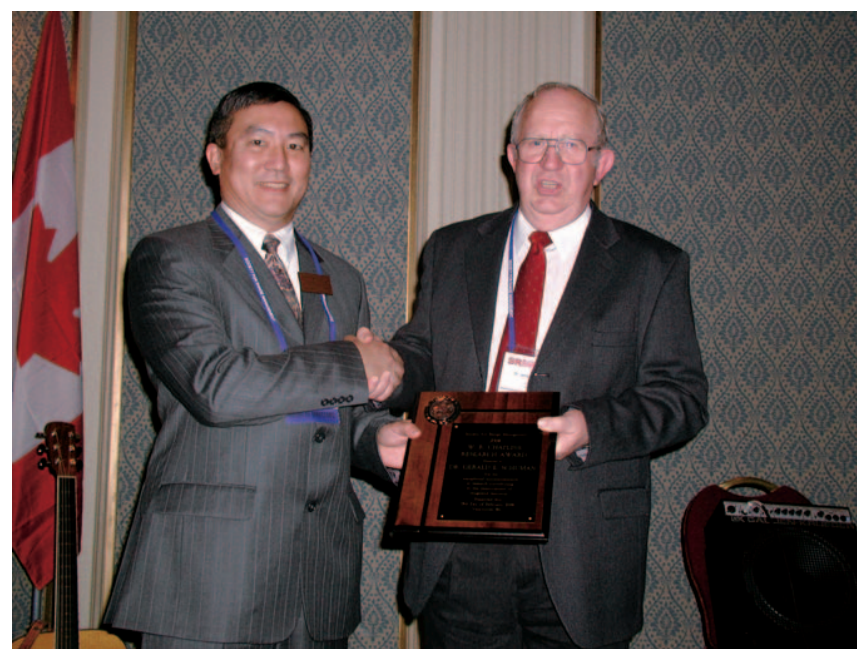

John Tanaka and Gerald Schuman

land management and natural resource agencies. Because this area of research is recognized as experimentally difficult and complex and does not readily submit to conventional approaches in research analysis, Jerry's contributions to improving the understanding of rangeland soil ecosystem responses to land management practices, and the development of new technologies to assess these responses, also represent significant advances to the scientific community. These contributions have extended conceptual theory used in developing sustainable management strategies for these complex ecosystems and have practical implications for policy development regarding possible carbon credit and greenhouse gas-trading programs.

Jerry's scientific reputation is clearly illustrated by his numerous invitations to international and national meetings and his selection as a Fellow in 4 major professional societies: Soil Science Society of America, American Society of Agronomy, Society for Range Management, and Soil and Water Conservation Society.

Jerry's career epitomizes what the rest of us strive for: sustained excellence, impact, implementation of recommended strategies and practices by land managers, an illustrious publication record, and consummate respect among peers.

Thus, it is with great honor that we, hereby, present $\mathrm{Dr}$ Gerald (Jerry) E. Shuman with the 2006 W. R. Chapline Research Award.

The W. R. Chapline Stewardship Award was created in 1986 to provide recognition to members of SRM for exceptional accomplishments and contributions to the art and science of range management through specific rangeland entities.

The Deseret Land and Livestock Ranch located in northeastern Utah is widely recognized as one of the bestmanaged ranches in the United States. Established in 1891, for sheep grazing, the Deseret is a 200,000 acre, privately owned ranch, dedicated to the proper management of land, water, and animals. Owned and operated by the Farm 


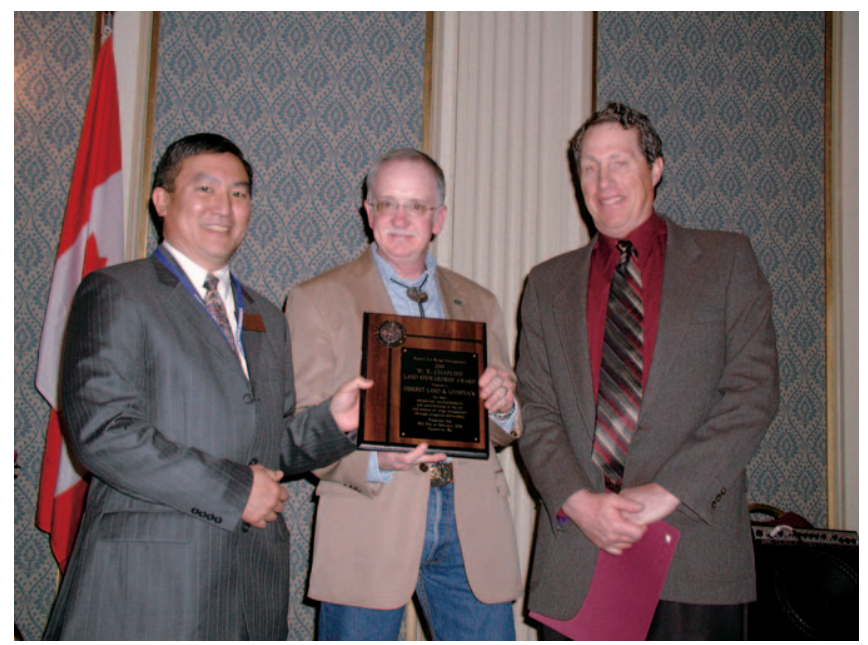

John Tanaka, Gregg Simonds, and Rick Danvir (not present: Bill Hopkin)

Management Company, a tax-paying entity of the Church of Jesus Christ of Latter-day Saints, the ranch mission is to "make a profit while maintaining or enhancing the resource." The 200,000 acres of rangelands on this property uniformly meet the criteria for being in a high state of ecosystem health. Approximately 5,000 mother cows, 3,000 yearlings cattle, and one of the healthiest mixes of wildlife in the region (including an estimated 3,500 mule deer, 2,300 elk, 175 moose, 700 antelope, 2,000 sage grouse, and 275 different species of birds) graze the ranch's rangelands.

This award recognizes the employees and volunteers that have contributed to the success of the Deseret Land and Livestock Ranch during the past 25 years-including those that have provided management and labor to the property and the LDS Church, which owns the ranch. This team has made major changes to the ranch that have improved its economic viability and ecological health. To achieve what they have on the ranch, those working the ranch have been innovators in land, livestock, and wildlife management, and the management techniques and ideas they have developed on the Deseret are being applied by other ranchers throughout the western United States. The ranch has been actively involved in outreach to inform other ranchers and the public about the opportunities for, and benefits of, improved rangeland management. The ranch workers have hosted numerous tours-including many SRM tours-to share their philosophies, experience, and knowledge with many diverse groups. They have been recognized by many organizations for the outstanding job they do in managing the land, water, and animal resources of the Deseret Land and Livestock Ranch.

The Society for Range Management is proud to join these other groups by presenting to the ranch the W. R. Chapline Stewardship Award - the highest award presented by the Society for those involved in resource management. Three individuals-all active SRM members-will accept the award on behalf of the ranch employees, volunteers, and owner. These individuals are Gregg Simonds, who managed the Deseret from 1981 to 1994; Rick Danvir, who joined the ranch as a wildlife biologist in 1983 and has been responsible for the wildlife management program on the ranch since 1990; and Bill Hopkin, who was responsible for livestock operations from 1983 to 1994 when he succeeded Gregg as manager.

\section{Outstanding Achievement Awards}

The Outstanding Achievement Awards are presented by the Society for Range Management to members and other qualified individuals and groups working in rangelands. The Outstanding Achievement Awards have been divided into 2 groups: Research/Academia and Stewardship (ranchers, agency professionals, and consultants).

\section{Research/Academia}

Dr Amitrajeet A. Batabyal grew up in the small railway town of Chittaranjan, West Bengal, India, before moving to the United States in 1983. He was educated in economics at Cornell, the University of Minnesota, and the University of California at Berkeley. He began to seriously research issues and problems in range management while at Utah State University.

While reviewing the relevant literature on the use and management of natural resources and rangelands, Dr Batabyal noticed that although there were many claims about whether the stocking rate or the length of time that animals grazed a particular rangeland was more important from a management perspective, there were absolutely no theoretical analyses of this important and much debated question-so he developed a novel stochastic model that clearly demonstrated the relative salience of stocking rate.

His 2002 Journal of Range Management article on the theoretical formation of the state-and-transition idea simply and nicely uses the theory of discrete-time Markov chains to show how the stochastic dynamics of a 4-condition-class rangeland can be modeled and understood. Although rangelands have often been conceptualized and managed from primarily an ecological perspective or an economic perspective, there is interest in jointly determined ecological-economic systems. His 2005 research showed that ecological and economic criteria are largely disjoint, except in unusual circumstances, and that optimizing one will not simultaneously result in the optimization of the other.

Dr Batabyal is a brilliant researcher and author, as exemplified by his book, Stochastic Modeling in Range Management: Selected Essays (Nova Science Publishers). He is internationally published and is a sought-after speaker. $\mathrm{He}$ also serves SRM as a book reviewer (20-plus published reviews in JRM/REM and Rangelands).

Dr Batabyal is one of the youngest holders of an endowed chair at the Rochester Institute of Technology (Arthur J. Gosnell Chair/Professor of Economics). He is most deserving of the Outstanding Achievement Award. 


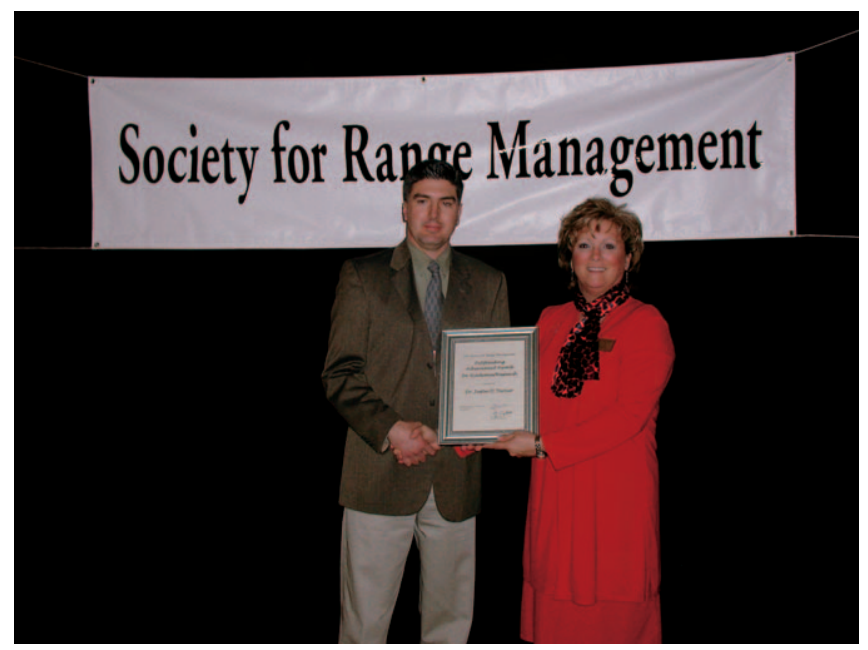

Justin Derner and Angela Williams

Dr Justin D. Derner has made outstanding contributions to the Society for Range Management both through his work with students and through his research. His work with students comes naturally because he was fully involved in the Range Club at the University of Nebraska. He served as the team coach for the Undergraduate Range Management Exam at both Oklahoma State University and Texas A\&M University Range Club. He continues to work with students at the University of Wyoming Range Club and assists with coaching and training of students even though he is located 50 miles from the University - he doesn't let 50 miles deter him from his interest or his love of working with students. He is currently serving as Chair of the Undergraduate Range Management Exam Committee and is a member of the Student Activities Committee at the International Society level. Justin is one of those special people who is an effective teacher and very well liked by the students because he relates well to them. Dr Derner has significantly influenced many students to continue their education and training in rangeland science.

Dr Derner has also developed an outstanding research program in rangeland ecology and the effect of climate change on rangeland ecosystems. Justin has published more than 35 refereed scientific journal articles, made more than 50 presentations, and been sought out to speak at more than 20 regional and national workshops or conferences. He has attended 16 annual meetings of the Society and made 17 presentations at those meetings. These statistics are quite extraordinary considering that he has been in his research career for only 6 years. Justin's research involves very timely and important rangeland issues: the effects of climate change on rangeland ecosystems, rangeland carbon sequestration, and evaluation of the "state and transition" model of plant community change. This theoretical approach to rangeland ecology is being adopted by land management agencies with limited or no research data to support or refute the model. His research includes areas of prime importance to future rangeland management and represents very challenging and difficult areas of research, but Justin doesn't let that discourage him-he loves the challenge and the natural resource-rangeland!

Dr Justin D. Derner is an extraordinary recipient for the Society for Range Management's Outstanding Achievement Award.

Dr Linda H. Hardesty, teacher, researcher, and extension specialist from Washington State University, is one of the truly capable and dedicated rangeland managers in the Society for Range Management. She has been active in her pursuits of rangeland improvement and managerial excellence throughout her entire 31-year professional career. She has made a tremendous difference wherever she has been, be it locally, regionally, nationally, or internationally. She has mentored many students, all of whom have gone on to productive and useful careers. She has successfully garnered grants and produced practical, useful research that has made a dramatic difference in the management and economic practicalities at each site and in every nation where she has worked. She is a wonderful undergraduate teacher whose student evaluations at the end of each term indicate that "she cared," "she taught me more than any other instructor at the University," and "she knows her stuff, has enthusiasm for it, and really knows how to sell it!"

Dr Hardesty's efforts within the professional Society for Range Management are strong and commendable. She works unselfishly for the betterment of rangelands and for the people associated with them. She has served on many SRM committees, has been President of the Pacific Northwest Section, served on the SRM Board of Directors, and has patiently and capably given depth and breadth to our organization and profession.

Dr Hardesty is a soft-spoken, gentle person who attempts to see the best in every situation and person. At the same time, she has strong goals and ethics, a sense of right and wrong, and a desire to make the world more livable because of her efforts. And she has done so! The world, its students, its landowners, her peers, and society are better because $\mathrm{Dr}$

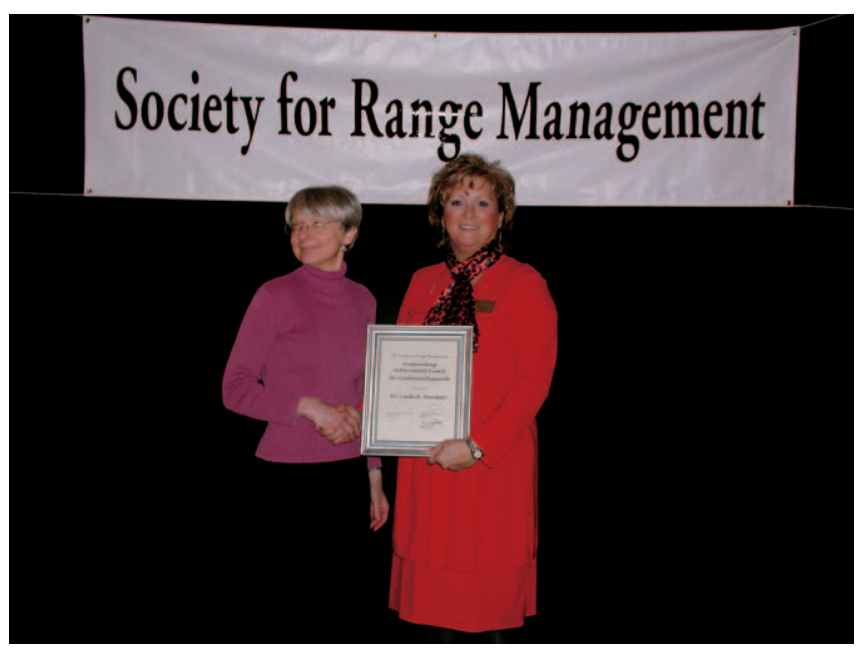

Linda Hardesty and Angela Williams 


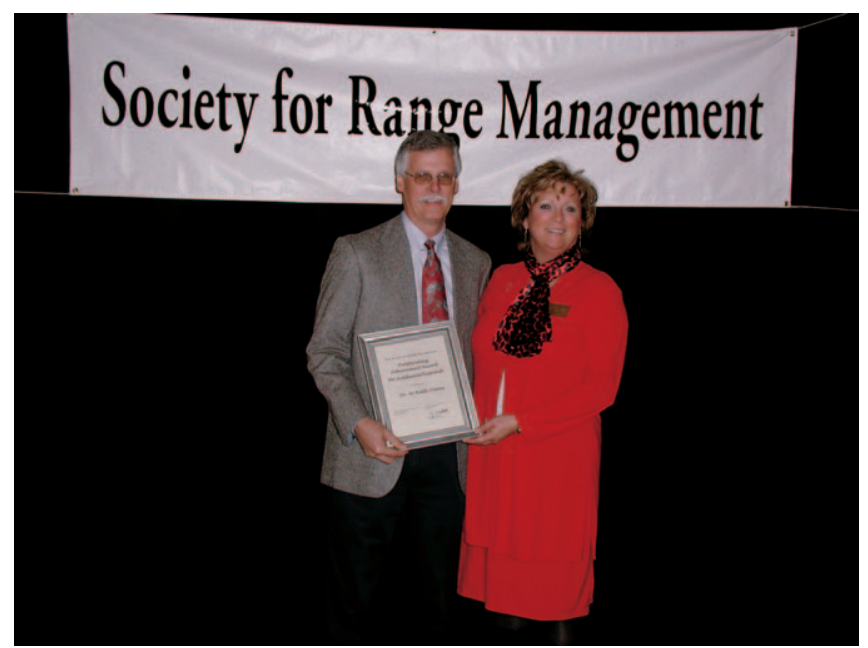

M. Keith Owens and Angela Williams

Hardesty has spent her considerable energy, time, and talent on the behalf of the rangelands of this planet!

Dr M. Keith Owens has a worldwide reputation for excellence in rangeland management research. During the past 15 years, he has been awarded $\$ 2,500,000$-plus for individual and joint research proposals to investigate ecological and managerial questions at multiple spatial scales. A central issue in Texas has been the availability and sustainability of water resources. Dr Owens has led efforts in understanding water use patterns in dominant trees and shrubs of the Edwards Plateau in Texas. This work has largely been on individual leaf, branch, and plant scales and has been incorporated into simple models for plant community water use. With collaborators, he has also been investigating water production from small watersheds and experimental rainfall simulator plots. He has worked with local and state entities to develop a network of experimental sites over a wide geographic range and to provide the data on a nightly basis through the Internet. Projects at a larger spatial scale have included foraging behavior of domestic livestock and wildlife within individual plant communities and fire behavior during summer fires in south Texas. Larger spatial-scale projects include foraging patterns of cattle and deer in large (2,500 acre) pastures and sampling protocol and foraging behavior of reindeer in the Bering Land Bridge National Preserve in Alaska. Ranchers and range professionals are both looking to Dr Owens for leadership in the management and understanding of rangelands.

A hallmark of Dr Owens' research is his ability to develop interdisciplinary teams of scientists to address specific problems facing Texas ranchers. Dr Owens has been active within Texas A\&M University's Texas Agricultural Experiment Station in Uvalde, Texas (the Uvalde Center), the Department of Rangeland Ecology and Management, and the College of Agriculture and Life Sciences. He has been an active member of the departmental tenure and promotion committee that evaluates all teaching, research and extension faculty with the Department of Rangeland Ecology and Management, and on the college Tenure and Promotions Committee. He has also participated in the Experiment Station Committee on Policy's Leadership Development course to enhance his capabilities in agricultural leadership. $\mathrm{He}$ is a member of a long-term research and management team at the Uvalde Center, which sets priorities for research in the context of a viable ranch enterprise. These accomplishments are the basis for recognition of Dr Keith Owens with the Society's Outstanding Achievement Award.

Dr Anthony (Tony) J. Svejcar, as scientist and Research Leader for the USDA-ARS in Burns, Oregon, has exceptional and sustained research accomplishments that have helped shape the science and management of rangeland resources. Tony is recognized nationally because he has dedicated his career to understanding and improving our rangeland resources, has worked tirelessly to bridge the gap between range science and range management, and has fostered the development of range science by building the largest rangeland research program in the Great Basin and surrounding ecosystems.

Dr Svejcar pioneered the use of stable isotope ${ }^{13} \mathrm{C}$ for carbon cycle research (in both plant and animal), and he initiated the ARS $\mathrm{CO}_{2}$ Flux Network, an effort to identify the influence of US rangelands on the global carbon cycle. Tony and his coworkers have provided substantial knowledge about the ecology and management of western juniper to land managers throughout the western United States. He has helped frame and define our knowledge on the ecology of riparian vegetation and provided guidance on managing the impact of livestock on riparian ecosystems. Dr Svejcar has studied the effects of precipitation timing on intact native sagebrush plant communities, and he has developed ecologically based models and principles useful in protecting these systems from invasion by weeds.

Perhaps Dr Svejcar's greatest contribution to rangelands has been to direct the Eastern Oregon Agricultural

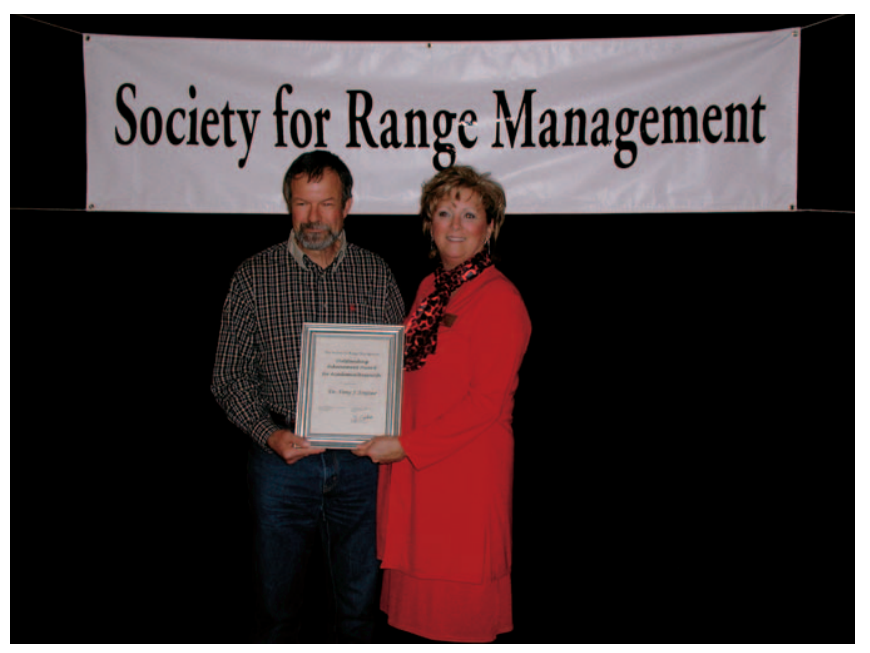

Tony Svejcar and Angela Williams 


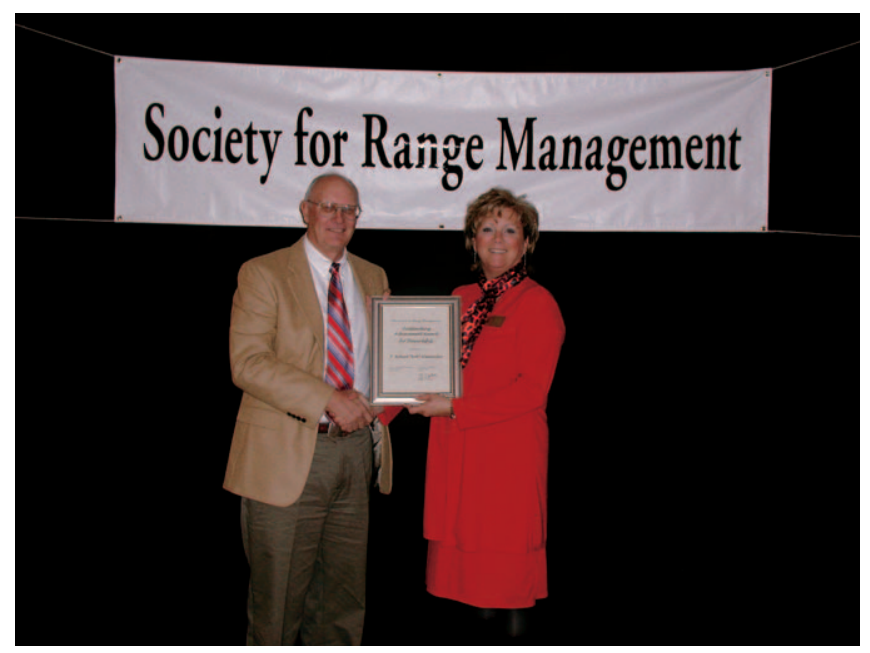

Bob Alexander and Angela Williams

Experiment Station into a high-quality, energetic, and productive research program. His excellent research skills are only surpassed by his ability to motivate, mentor, and lead other scientists to make their own substantial contributions to understanding and managing our treasured rangelands.

\section{Stewardship}

Robert (Bob) Alexander has, for 37 years, practiced and promoted the art and science of rangeland management. From the field offices of the Bureau of Land Management (BLM), to the desert rangelands of the Middle East, to the Beltway environment of Washington, DC, and finally, to the BLM state office in New Mexico, Bob has constantly worked for the conservation of rangelands.

Bob has numerous qualities that have served him and his profession well. There are 2 that are of particular significance in support of this award nomination.

First, he has never ceased to learn, adapt, and adopt. Even after more than 30 years of experiences, he still looks to understand new information, to develop new ideas, and to influence public land policy. For example, he was an important collaborator and coauthor in the 2003 publication on the development of state-and-transition models for rangelands, published in the Journal of Range Management. He was 1 of 2 people who started that program, which resulted in the $J R M$ publication and which continues today.

Second, Bob works constantly to bring different groups, agendas, and perspectives together into collaborative efforts. Whether as a Section President or as a Range Conservationist, he has worked to get people and groups to communicate and to move forward. His work with the rangelands standards and guidelines is one example.

Bob is a dedicated, hard-working, effective, and creative range manager. He deserves this award from the Society for Range Management.

Ted and Olive Perrin own and operate the 12,775-acre

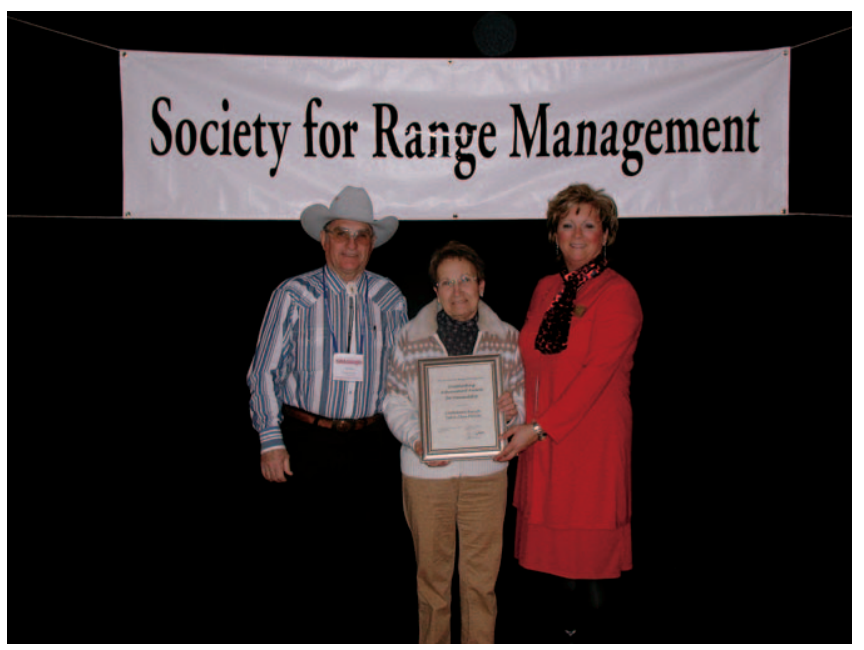

Ted and Olive Perrin and Angela Williams

Castleland Ranch in the Northern Mixed Prairie near Beechy, Saskatchewan, Canada. Castleland Ranch is a recognized leader in range management in the Canadian ranching industry. Forward-thinking and conservative range management on Castleland Ranch ensures sustainable grazing resources through extremes in climatic conditions over the short and long term. Many of the long-standing management approaches of Castleland Ranch are new technology for many producers.

Drought is a fact of life and an overriding consideration in the management of Castleland Ranch. The Perrins recognize the value of planned grazing systems that include conservative stocking rates, resting of plants during the growing season, once-over grazing, balanced forage availability and livestock numbers, and drought-proofing. Maintaining relatively stable animal numbers from year to year has been a major benefit derived from drought-proofing the range on Castleland Ranch.

Environmental stewardship on Castleland Ranch has been recognized by the Perrins' receiving The Saskatchewan Environmental Stewardship Award, The Canadian Environmental Stewardship Award, and the Prince Philip Heritage Award. The Perrins have cooperated with several conservation organizations, and they have been involved in rangeland studies conducted by universities.

Ted and Olive Perrin are extensively involved in the ranching industry and community activities. Ted was a member of a contingent of ranchers and rangeland specialists belonging to the Society for Range Management that toured rangelands of Inner Mongolia in 1990, sharing technology and range management practices. Ted is also a mentor for local producers who want to improve their range management.

Ted and Olive Perrin realize that ranching and range management are all about conserving natural resources for future generations. The Perrins strive to maintain a high quality of life and a lifestyle that is as rich, diverse, and generous as the 
landscape in which Castleland Ranch is located. Applying principles of range management that allow sustainable use of rangeland resources has been rewarding, as evidenced by humble and happy landowners and healthy rangelands.

Ted and Olive Perrin of Castleland Ranch are deserving recipients of the 2006 Outstanding Achievement Award.

Jeffery L. Printz has been a gracious contributor to rangeland management technology throughout his career. He has worked in various positions throughout the state of North Dakota. His current position with USDA-Natural Resources Conservation Service (NRCS) as the State Rangeland Conservationist has enabled him to be involved with the development and implementation of technical guidelines and standards, technical presentations and publications, and education of peers, agency personnel, and producers in relation to rangeland management. Jeff has participated in the collection and interpretation of rangelandrelated data to be used in statewide references. He has helped complete investigation studies and to develop ecological sites and forage suitability groups to determine characteristics and classification for use in planning and application of rangeland resource management systems. Currently, he serves on the Ecological Site Description task force. As a task force member, he has helped develop the regional strategy plan for new ecological site descriptions and forage suitability indexes for each state in the region. Jeff has worked with individual producers, producer groups, and state and federal agencies to help correlate these standards and to promote a uniform understanding of rangeland management objectives.

Jeff also has statewide responsibility in North Dakota for NRCS' Forage Quality and Animal Well-being project and the associated Nutritional Balance Analyzer program, which is a nationwide project, involving a cooperative agreement between NRCS and the Grazingland Animal Nutrition Lab at Texas A\&M University. NRCS field staff work with ranchers in determining the diet quality their grazing animals are obtaining from the forage available to them. Jeff provides overall leadership for this program and trains NRCS employees in the collection method, operation of the computer software, interpretation of the results, and overall quality control.

Jeff has also been very dedicated to the Society for Range Management. He has served as an inspirational force for both new and old members alike. His cheery attitude creates a positive and inviting environment for members to become involved in SRM activities. Jeff has served on various committees over the years and has even served as a North Dakota Chapter President and a Northern Great Plains Section (NGPS) President. He has also been involved with youth activities, such as the North Dakota Regional Range Judging Contest and North Dakota Youth Range Camp.

Since the National Research Council issued its report on Rangeland Health in 1994 and the Society for Range Management issued its report on Unity in Concepts and

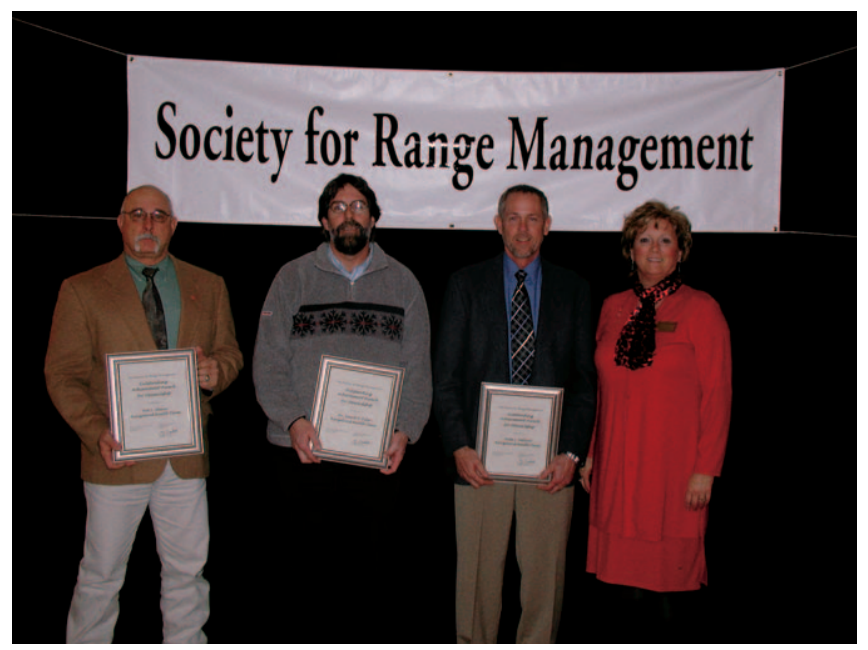

Pat Shaver, David Pyke, Mike Pellant, and Angela Williams (not present: Jeff Herrick)

Terminology in 1995, Jeffrey E. Herrick, ARS; Mike L. Pellant, BLM; David A. Pyke, US Geological Survey (USGS); and Pat L. Shaver, NRCS, have worked to determine how the ideas included in these reports can be incorporated into rangeland management. This interagency team has conducted field work to better develop the ideas introduced in the original publications, authored peerreviewed and technical publications summarizing what they learned through these field studies, and conducted many workshops to demonstrate the utility of the rangeland health concept.

The Rangeland Health Team has more fully developed the idea introduced in Rangeland Health of how multiple attributes could be used for assessment of the soil, watershed, and biotic conditions of a site. The team brought into the rangeland health assessment process important components of SRM's Unity in Concepts and Terminology report, particularly on the importance of ecological site descriptions. The team has consistently emphasized that a rangeland health assessment is a point-in-time evaluation that can help a resource manager identify areas with problems that need to be addressed-in other words, a way to prioritize work. The team emphasizes that what has caused a problem cannot be determined from a rangeland health assessment nor can rangeland health be used to monitor trends.

In summary, the Rangeland Health Team has taken basic concepts - developed by the National Research Council, the Society for Range Management, and many rangeland scientists and managers - and has advanced these concepts to a new level, has taken the ideas to the field for numerous tests, and has provided the rangeland management community with new tools to evaluate rangelands.

The Society for Range Management is pleased to recognize Jeff Herrick, Mike Pellant, Dave Pyke, and Pat Shaver for their important contributions to our profession with the Outstanding Achievement Award. 


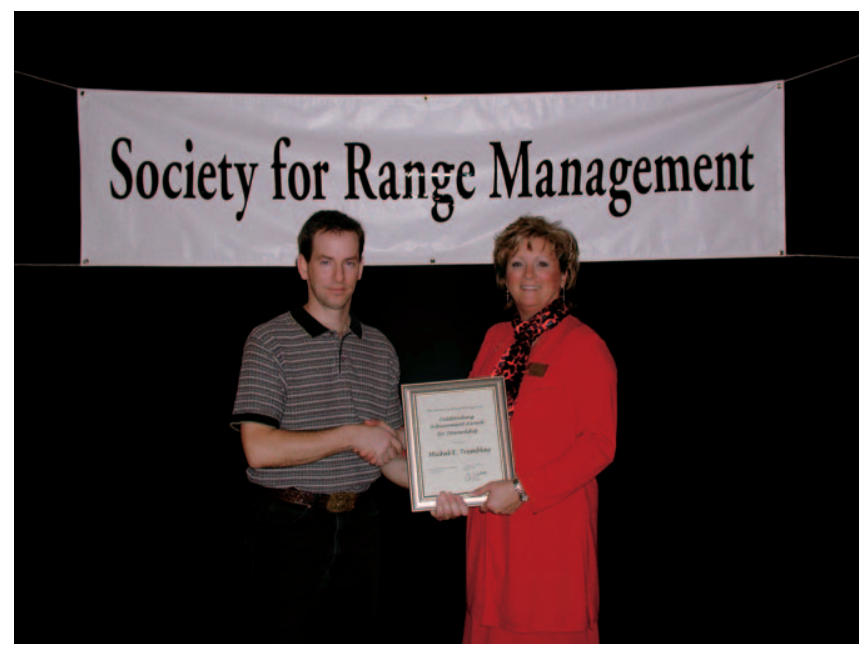

Michel Tremblay and Angela Williams

Michel E. Tremblay is presented the Outstanding Achievement Award for his continued service and dedication to improving the management and conservation of rangeland resources and the rangeland management profession. He has been an active member of the Northern Great Plains Section for more than 15 years, taking on a wide variety of executive roles.

As Provincial Forage Specialist for Saskatchewan, Canada, since 1992, Michel has played a key role in delivering sound technical advice to other government departments, the forage industry, and forage producers. Growing up in an agriculture environment, Michel has complimented that knowledge with a BS in Agriculture and an MS in Range Management. Michel's agriculture background, combined with his knowledge of Saskatchewan's agriculture, livestock, and forage industries, has led him to become a key range management professional in Saskatchewan that other agencies and producers count on for extension information. He has authored numerous fact sheets and helped revise range related documents - these publications are considered keystone information on forages and range management for Saskatchewan. Michel has continued to follow developments in the native forages industry and promote them where feasible. He also has played a key role in promoting the wise use of native rangelands to wide audiences in the province.

Michel has been instrumental in his role as Provincial Forage Specialist with Saskatchewan Agriculture and Food in bringing together and working with partner agencies to develop programs and extension materials that benefit Saskatchewan's livestock and forage industry. He has been influential in ensuring the long-term viability of the Saskatchewan Forage Council through fundraising, carrying out executive roles, and providing basic networking with industry. At a national level, he has also played a leadership role in developing Saskatchewan's forage industry. He is committed to continually developing professionally by reading new information in range management journals and publications and by attending workshops and conferences throughout Canada and the United States.

Michel's long-term service and passion in advancing the art and science of rangeland management make him a most worthy recipient for the SRM 2006 Outstanding Achievement Award.

\section{Sustained Lifetime-Achievement Award}

The Sustained Lifetime-Achievement Award is presented by the Society for Range Management to members for long-term contributions to the art and science of range management and to the Society for Range Management.

George S. Cook completed his BS in Range Management at Utah State University (USU). He then began a long and distinguished career with USDA-NRCS, where he worked as a Soil Conservationist, Range Conservationist, and District Conservationist. George has received many awards in the past, such as the Utah Soil Conservation Commission "Graham S. Quate" Award, the Utah Section SRM Range Manager of the Year Award-1995, the SRM Fellow Award-2000, and the USU Alumni Association Lifetime Achievement Award-2002. He has been very active in the Society for Range Management at the national and section levels, including service as Utah Section President in 1991 and SRM Information and Education Committee (I\&E) member in 1995-1996. He is a person who faithfully attends all the section and national SRM meetings, even now that he is retired.

George's most distinguished services to the Utah Section have been to host Dutch oven and steak cookouts around the state to collect money for the section's scholarship fund. This has earned the section approximately $\$ 50,000$, which has been invested into the scholarship fund to promote the range management profession to students. Also, for 23 years, George has annually given freely of his time to teach and help USU Extension at the Utah Natural Resources Field

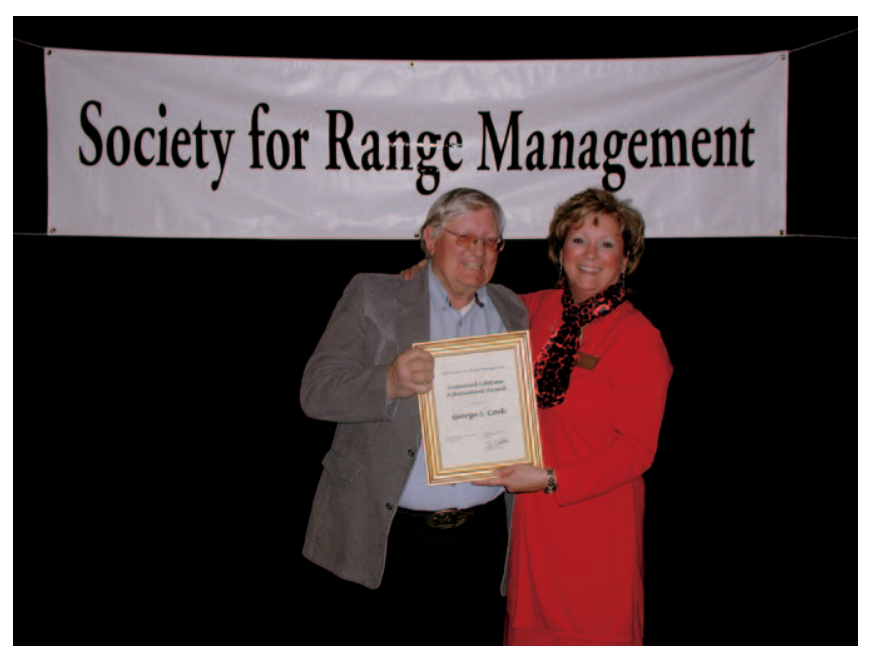

George Cook and Angela Williams 
School (UNRFS), which hosts 8-25 high-school students, who learn about range and natural resource management. George's humble, patient, and gentle teaching style has positively affected approximately 300 students.

While at NRCS, George wrote many of the Range Site Descriptions that are now or have been developed into Ecological Site Descriptions. He brings a passion to the job, not only for the science but also for the information that flows out of that science. His close work with the western states Plant Materials Centers has provided experimental and new plant varieties for rehabilitation and planting trials on many harsh and inhospitable sites, such as coal mine tailings or other disturbed sites. George has helped many of the new NRCS personnel become familiar with ecological sites and with the land they are responsible for managing. He is an authority in conservation of the land and in plant identification and is a champion for conservation transfer to those who follow in the profession of range management.

George and his wife, Sarah, have 2 children and 6 grandchildren.

Paul T. Tueller is recognized internationally as a leader in remote-sensing applications on rangelands. He joined the Society for Range Management in 1956. Looking down the long trek into history, he has seen the vagaries of weather, personnel changes, issues, controversies, priorities, legislation, and land uses. He has sweated on the pages of 1950s field notebooks and worked with some of the highest and most current digital technologies that the National Aeronautics and Space Administration (NASA) has at its disposal. He has worked in both the Mojave Desert and the Great Basin sagebrush and sagebrush steppe systems of Nevada.

He has seen it all from the ground, from the air, and from space, an accomplishment no one else can claim. Paul bleeds rangelands. The profession is his passion, and he has dedicated himself to it for nearly 50 years. He is best known for

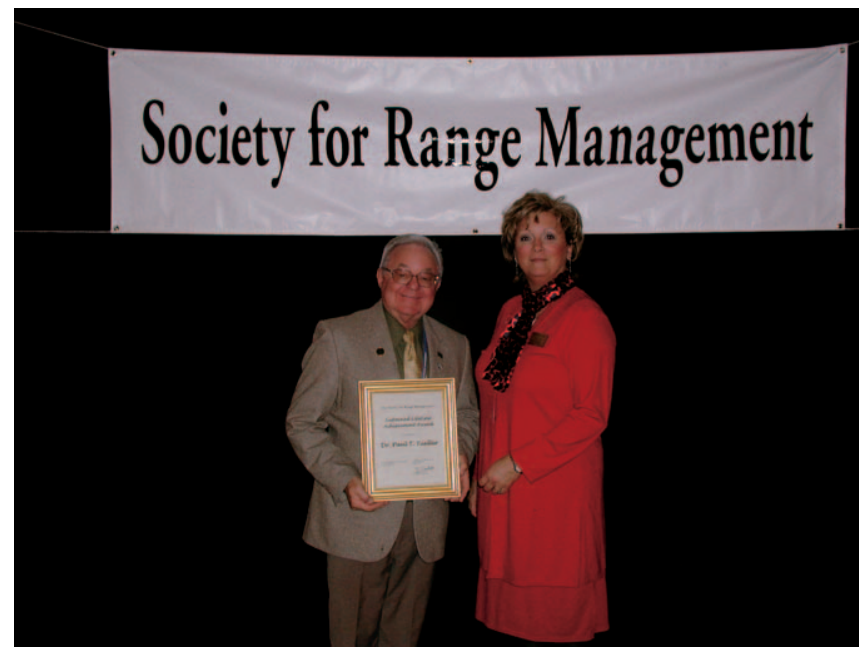

Paul Tueller and Angela Williams his precedent-setting research in remote sensing. Paul is one of the pioneers in this area of science and has not only assisted in development of the technology itself but also been a champion and innovator in applying remote sensing to rangeland management.

In our profession, the highest tribute one can give is to acknowledge them as a Rangeman. Paul Tueller is a Rangeman. He is a credit to our profession - an ethical, moral, enthusiastic, positive, and beloved family man. His former graduate students are located all over the country; many of them have served and are serving as district managers and forest supervisors in federal land management agencies. We cannot begin to measure the effect their relationship with Paul and his research has had on our rangelands. The body of research that Paul has accumulated throughout his nearly 50 -year career is impressive. He is a research icon in our profession and deserves formal recognition as such.

\section{Outstanding Young Range Professional}

The Outstanding Young Range Professional Award is presented by the Society to an individual member who has demonstrated extraordinary potential and promise as a range management professional. This award is presented as an encouragement for outstanding performance by young men and women entering the profession of range management.

Jason C. Hohlt is a Rangeland Management Specialist for the Natural Resources Conservation Service in Alice, Texas. Since coming to work for the NRCS, Jason has worked in Victoria, Jim Wells, Live Oak, Duval, Brooks, McMullen, and Kleberg counties.

Some of Jason's accomplishments include a BS degree in Rangeland Ecology and Management from Texas A\&M University (TAMU) and an MS in Animal Science from Texas Tech University. He holds a basic firefighter certificate from the BLM and is a Certified Wetland Delineator. $\mathrm{He}$ has been Treasurer of the TAMU Range Club and President of the TAMU Soil and Water Conservation Society. Jason is

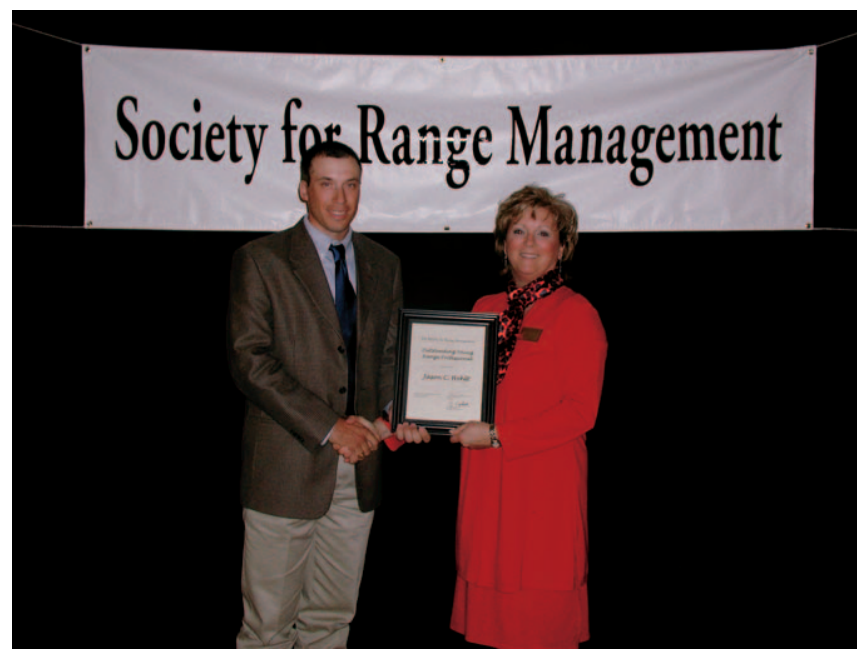

Jason Hohlt and Angela Williams 
the recipient of the National Soil and Water Conservation Society Achievement Scholarship, Range Club Outstanding Participation Scholarship, and a Certificate of Merit from NRCS for Outstanding Leadership on the Natural Resources Inventory Team.

Jason is highly intelligent, learns quickly, is highly motivated, and practices a high moral code with absolute integrity. It is truly a rarity to find a young employee as enthusiastic, positive, inquisitive, and with as much integrity and work ethic as Jason. Jason has a heart for rangelands and resource management, and his enthusiasm for these is contagious to all who come in contact with him. Jason is a self-starter, and no job, regardless of its complexity, daunts him.

Jason is a natural leader. His ability and willingness to take the leadership role is a quality few young employees possess. He has a special ability to communicate effectively with others while promoting sound resource management and will stand for what is technically sound even though it may not be the most popular choice.

Jason's love for his chosen profession and the rangeland resource is evident to all who work with him, and it is an honor to recognize Jason Hohlt as the 2006 recipient of the SRM Outstanding Young Range Professional Award.

Lee A. Knox is one of SRM's shining stars. He has an enthusiasm that is infectious. His leadership skills have been recognized by the Texas Section and by his employer, the Natural Resources Conservation Service. Lee has been active on numerous Texas Section committees and is currently serving as Chair of the Youth Activities Committee. This committee is responsible for the annual Youth Range Workshop. He was selected to be a watershed manager for the NRCS Conservation Security Program (CSP). In this role, he had a positive impact on the other CSP watersheds in the San Angelo zone. Lee came to NRCS from Texas Cooperative Extension (TCE). The TCE honored him in 2002 with its District 10 Outstanding Young Agent Award.

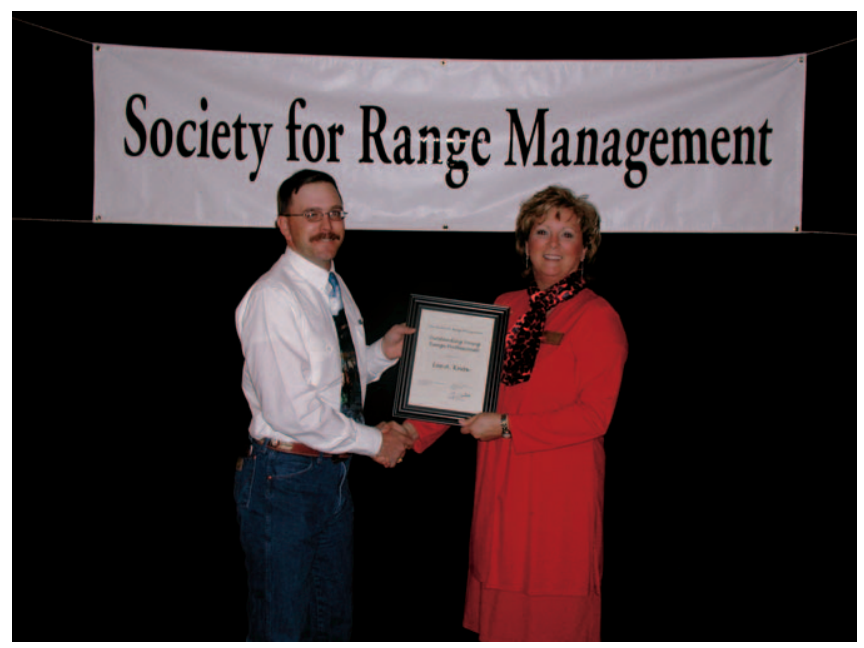

Lee Knox and Angela Williams
Lee earned his BS in Rangeland Management from Texas A\&M University in 1996. That same year, he was selected by the professors of the department to receive the Leadership Award, their most prestigious student award. He earned his Master's degree in range management from New Mexico State University. At the 1998 Annual Meetings in Guadalajara, Mexico, Lee won the Graduate Student Paper Contest, while presenting the results of his MS thesis.

Lee's enthusiasm for, and dedication to, rangeland management and SRM makes him a shining example for other young professionals. He will be a leader at the section and society level for many years. It's this level of commitment and dedication that make him deserve to be recognized as one of the 2006 Outstanding Young Range Professionals.

Melissa R. Teague is an exemplary model of a Rangeland Management Specialist, which stems from a well-rounded knowledge base and an undeniable passion for rangelands. Melissa has been a Rangeland Management Specialist for the NRCS for 8 years in various locations in Texas and Oklahoma. She has been an area Range Specialist in southwest Oklahoma for 4 years, where she is the "go to" person for range-related topics. She has provided excellent leadership in an area that previously lacked support for range activities. Melissa has made a difference!

Melissa received her BS in Rangeland Ecology and Management at Texas A\&M University and her MS in Agribusiness and Economics at West Texas A\&M University. Her SRM activities include the Plant ID team and the Undergraduate Range Management Exam (URME) team at TAMU, the Student Activities Committee for 7 years, CoChair of the URME exam for 6 years, Coordinator for Tapping the Top Mixer, Secretary Treasurer for the Oklahoma Section in 2003-2004, and first vice president of the Oklahoma Section in 2004-2005, and she is currently the President of the Oklahoma Section. Since 2001, Melissa has been a coordinator and instructor for the Black Mesa Ecological Academy, a range and wildlife camp that brings together high-school students from Oklahoma, Texas, Kansas, New Mexico, and Colorado. In 2004, she was selected as the chair for this Academy, where the top student is selected to attend the National SRM meeting to compete in the High School Youth Forum. Melissa is also an invaluable member of a team that assists in the set up and instruction of the National Range Judging Contest held in Oklahoma City every year.

Melissa's tireless efforts to support rangeland management and sustainability and the endless amount of time spent in educating the range managers of tomorrow make her unquestionably deserving of this award.

\section{Range Science Education Council Outstanding Undergraduate Teacher Award}

The Outstanding Undergraduate Teaching Award is presented annually to the individual who makes the greatest contribution to undergraduate education in the broad discipline of range science. 


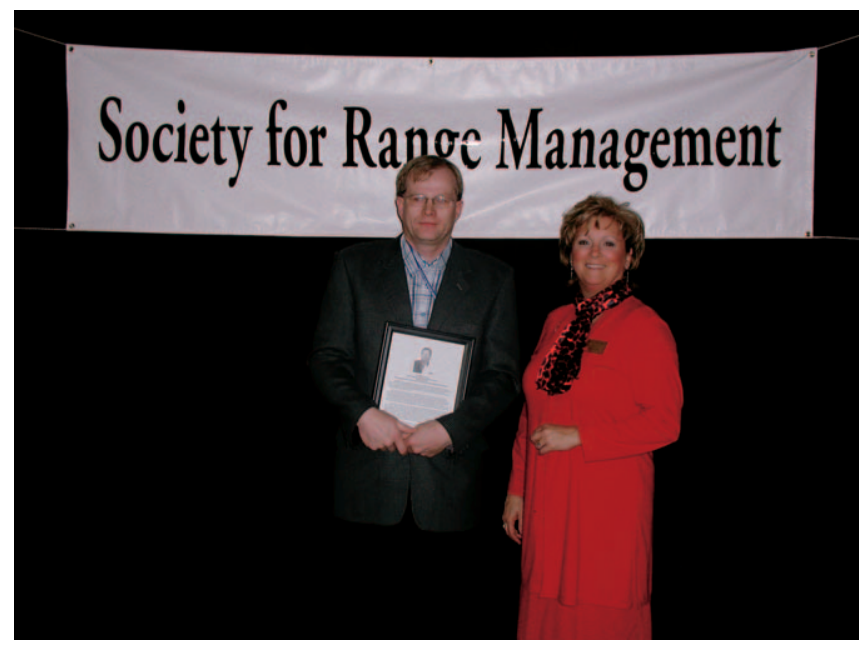

Barry Irving and Angela Williams

The award is presented jointly by the Range Science Education Council and the Society for Range Management.

The Range Science Education Council and the Society for Range Management are happy to present the 2006 Outstanding Undergraduate Teaching Award to Dr Barry Irving from the University of Alberta.

Dr Irving is well known among his colleagues as one of the most successful coaches of students in the Plant and URME contests. Under his direction, more than 70 individuals and teams have received awards in international competition. Students and fellow instructors at the University of Alberta recognize and admire Dr Irving for the hundreds of hours required each year to coach teams and advise the range club. Barry also works to make sure his students get summer work experiences and helps them find careers upon graduation. Students state that Barry is always trying to find ways to give students a great education, and he gives generously of his time beyond the classroom.

In his teaching efforts, Dr Irving is always trying to challenge students to achieve their highest personal best. Barry employs innovative and effective classroom experiences and teaching tools that coax students to rise to excellence. He has created interactive computer modules that quiz students on plant identification and classification. Barry is also known for making education fun and for engaging students by turning tests and assignments into games and team activities. For example, Dr Irving created "Plantionary," a game adapted from the Pictionary board game, where students guess families, genera, and species based on a partner's simple plant drawings. Students commonly note that Dr Irving pushes them to do their best work. Barry guides them beyond "book learning" and helps them achieve critical-thinking skills and confidence in their knowledge.

Dr Barry Irving excels in the classroom and beyond to help students understand rangelands and to achieve their career goals; therefore, he is recognized with the Outstanding Undergraduate Teaching Award for 2006.

\section{First Annual SRM International Travel Fellowship 2006}

The SRM International Travel Fellowship, presented for the first time in 2006, is awarded to a rangeland scientist or manager from a developing country. The purpose of this fellowship, which includes a \$1,000 travel stipend, is to foster international exchange about advances in rangeland ecology and management and to promote participation in SRM by rangeland scientists and managers from developing countries. The fellowship is competitive and is awarded on the basis of scientific merit and applied significance of research, financial need, professional development objectives, and clarity of expression in English.

The 2006 winner of the International Travel Fellowship is Rebeca Ideth Hernández-Paz, an MS student in Environmental Systems at the Instituto Superior de Estudios Tecnológicos de Monterrey in Monterrey, Mexico, for her paper titled "Organochlorine compounds in water and sediments of three tributaries of the Rio Bravo in Coahuila, Mexico." 


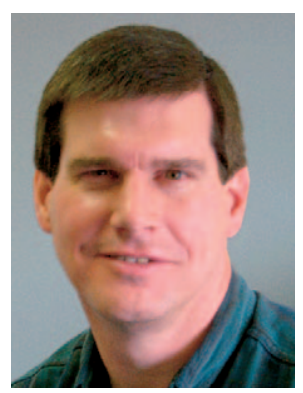

Jeff Mosley

\section{Browsing the Literature}

This section reviews new publications available about the art and science of rangeland management. Personal copies of these publications can be obtained by contacting the respective publishers or senior authors (addresses shown in parentheses). Suggestions are welcomed and encouraged for items to include in future issues of Browsing the Literature. Contact Jeff Mosley, jmosley@montana.edu.

\section{Animal Ecology}

Modeling post-fledging survival of Lark Buntings in response to ecological and biological factors. A. A. Y. Adams, S. K. Skagen, and J. A. Savidge. 2006. Ecology 87:178-188. (Department of Wildlife and Fisheries Biology, Colorado State University, Fort Collins, CO 80523). Drought had a strong negative impact on survival of young lark buntings, a shortgrass prairie bird.

Trends associated with residential development in riparian breeding bird habitat along the Snake River in Jackson Hole, WY, USA: implications for conservation planning. C. M Smith and D. G. Wachob. 2006. Biological Conservation 128:431-446. (Teton Science School, PO Box 8699, Jackson, WY 83002). Neotropical migratory birds declined with increasing residential development, but food generalists, ground gleaners, and avian nest predators all increased with increasing residential development.

\section{Education}

At home on the range, level 1. M. Coley, K. A. Astroth, G. Cade, J. Dawson, T. M. Kappel, M. Cavey, E. Miller, C. Moseley, G. Hyde, E. Bergman, S. Roffe, D. Lucas, J. Whaley, V. Dupuis, A. Smith, J. Gill, and J. Mosley. 2005. Montana State University Extension Bulletin 5311. (\$5; Extension Publications, 115 Culbertson Hall, Montana State University, Bozeman, MT 59717). A team of range educators from Montana, Texas, Oklahoma, Idaho, Colorado, and Wyoming developed this rangeland management curriculum for grades 4 thru 8. Satisfies National Science Education Standards and is endorsed by the National Collection of 4-H Curricula.

\section{Grazing Management}

Effect of creep feed supplementation and season on intake, microbial protein synthesis and efficiency, ruminal fermentation, digestion, and performance in nursing calves grazing native range in southeastern North Dakota. J. J. Reed, A. L. Gelvin, G. P. Lardy, M. L. Bauer, and J. S. Caton. 2006. Journal of Animal Science 84:411-423. (J. Caton, Department of Animal and Range Science, North Dakota State University, Fargo, ND 58105). Supplementation with a wheat middlings and soybean hulls-based creep feed did not increase weight gains appreciably.

Impacts of simulated livestock grazing on Utah prairie dogs (Cynomys parvidens) in a low productivity ecosystem. E. Cheng and M. E. Ritchie. 2006. Oecologia 147:546-555. (College of Forestry and Conservation, University of Montana, Missoula, MT 59812). Prairie dogs preferred the moderate defoliation treatment plots over unclipped areas. 


\section{Hydrology/Riparian}

Occurrence, persistence, and expansion of saltcedar (Tamarix spp.) populations in the Great Plains of Montana. J. P. Sexton, A. Sala, and K. Murray. 2006. Western North American Naturalist 66:1-11. (A. Sala, Division of Biological Science, University of Montana, Missoula, MT 59812). Saltcedar stands establish where native trees and shrubs are not abundant, then saltcedar stands persist and expand over time.

Soil salinity patterns in Tamarix invasions in the Bighorn Basin, Wyoming, USA. C. G. Ladenburger, A. L. Hild, D. J. Kazmer, and L. C. Munn. 2006. Journal of Arid Environments 65:111-128. (A. Hild, Department of Renewable Resources, University of Wyoming, Laramie, WY 82071). Surface soils beneath saltcedar trees had greater salinity and lower $\mathrm{pH}$ than soil in interspaces. Soil salinity was lower than saltcedar stands in the southwestern United States.

Transverse and longitudinal variation in woody riparian vegetation along a montane river. J. M. Friedman, G. T. Auble, E. D. Andrews, G. Kittel, R. F. Madole, E. R. Griffin, and T. M. Allred. 2006. Western North American Naturalist 66:78-91. (US Geological Survey, 3215 Marine Street, Suite E-127, Boulder, CO 80303). In southwestern Colorado, sand-bar willow communities occurred on sites that were flooded once every 2.2 years or less, whereas stands of river birch trees were favored most by flooding that occurred less frequently, once every 2.2 to 4.6 years.

Vegetation, soils, and hydrogeomorpholgy of riparian patch types of a dryland river. K. J. Bagstad, S. J. Lite, and J. C. Stromberg. 2006. Western North American Naturalist 66:23-44. (J. Stromberg, MWH America, Inc., Chicago, IL 60604). Along the San Pedro River in southeastern Arizona, cottonwood-willow and saltcedar patches were inundated with water more frequently than mesquite patches. Cottonwood-willow patches had shallower groundwater than saltcedar or mesquite patches.

\section{Measurements}

Implementing a cooperative permittee monitoring program. E. Peterson. 2005. (Wyoming Cooperative Extension Service, PO Box 579, Pinedale, WY 82941). In straightforward language, this 18-page color brochure provides valuable tips about implementing cooperative monitoring programs on public land grazing allotments, bringing together ranchers and agency personnel.

Interpreting indicators of rangeland health, version 4. M. Pellant, P. Shaver, D. A. Pyke, and J. E. Herrick. 2005. Bureau of Land Management (BLM) Technical Reference 1734-6. 122 p. (BLM, PO Box 25047, Denver, CO 802250047). Describes qualitative methods for rapidly assessing how well ecological processes are functioning on rangelands.
The structure and functioning of dryland ecosystemsconceptual models to inform long-term ecological monitoring. M. E. Miller. 2005. US Geological Survey Scientific Investigations Report 2005-5197. 73 p. (http://pubs.usgs. gov/sir/2005/5197/). Presents conceptual ecological models that describe the structure and function of rangeland ecosystems in the Colorado Plateau region of Utah, Arizona, Colorado, and New Mexico. Intended to help resource managers identify vital signs to be monitored for long-term trends and ecosystem health.

\section{Plant-Animal Interactions}

Interactions between Euphorbia esula toxins and bovine ruminal microbes. S. L. Kronberg, F. T. Halaweish, M. B. Hubert, and P. J. Weimer. 2006. Journal of Chemical Ecology 32:15-28. (USDA-ARS, Northern Great Plains Research Lab, PO Box 459, Mandan, ND 58554). Leafy spurge was not toxic to rumen bacteria, but microbial activity in the rumen may have enhanced the toxicity of leafy spurge to cattle. This may explain why cattle often develop aversions to leafy spurge after eating it.

\section{Plant Ecology}

Inhibition of seed germination and seedling growth by hound's tongue (Cynoglossum officinale L.) seed leachate. A. Rashid, N. H. Furness, B. E. Ellis, and M. K. Upadhyaya. 2005. Weed Biology and Management 5:143-149. (Land and Food Systems, University of British Columbia, Vancouver, BC V6T 1Z4, Canada). Presents preliminary evidence that hound's tongue seeds exude allelopathic substances.

Reconstructing landscape-scale tree invasion using survey notes in the Medicine Bow Mountains, Wyoming, USA. M. D. Andersen and W. L. Baker. 2006. Landscape Ecology 21:243-258. (W. Baker, Department of Geography, University of Wyoming, Laramie, WY 82071). The relatively slow rate of tree invasion (ie, a 7.3\% decrease in forest openings in the last 110 years) was partially attributed to the area's dry climate.

\section{Rehabilitation/Restoration}

Biological control of Canada thistle in temperate pastures using high density rotational cattle grazing. S. L. De Bruijn and E. W. Bork. 2006. Biological Control 36:305-315. (E. Bork, Department of Agriculture, Food and Nutrition Science, University of Alberta, Edmonton, AB T6G 2P5, Canada). Prescribed cattle grazing was evaluated for controlling Canada thistle. Two intense defoliations per summer nearly eliminated this weed after 2-3 consecutive years of treatment.

Community response of nontarget species to herbicide application and removal of the nonindigenous invader Potentilla recta L. R. L. Sheley and M. K. Denny. 2006. Western North American Naturalist 66:55-63. (USDA-ARS, 
67826A Hwy 205, Burns, OR 97720). Native perennial grass cover increased after herbicide application to control sulfur cinquefoil, but picloram, metsulfuron, and clopyralid reduced forb densities in southeastern Montana.

Competition of giant smutgrass (Sporobolus indicus) in a bahiagrass pasture. J. A. Ferrell, J. J. Mullahey, J. A. Dusky, and F. M. Roka. 2006. Weed Science 54:100-105. (Department of Agronomy, University of Florida, Gainesville, FL 32611). Economic analyses indicated that giant smutgrass should not be controlled with hexazinone until ground cover of giant smutgrass reaches about $35 \%$.

Early season mowing improves the effectiveness of chlorsulfuron and glyphosate for control of perennial pepperweed (Lepidium latifolium). M. J. Renz and J. M. DiTomaso. 2006. Weed Technology 20:32-36. (Department of Plant Science, New Mexico State University, PO Box 30003 MSC 3AE, Las Cruces, NM 88003). Mowing alone did not control perennial pepperweed, but mowing followed by herbicide treatment to resprouting plants was very effective.

Effects of fire disturbance on grasshopper (Orthoptera: Acrididae) assemblages of the Comanche National Grassland, Colorado. L. Nadeau, P. E. Cushing, and B. C. Kondratieff. 2006. Journal of the Kansas Entomological Society 79:2-12. (Department of Bioagricultural Science and Pest Management, Colorado State University, Fort Collins, CO 80523). Spring burns in the shortgrass prairie did not affect grasshopper populations.

Effect of mowing and hexazinone application on giant smutgrass (Sporobolus indicus var. pyramidalis) control. J. A. Ferrell and J. J. Mullahey. 2006. Weed Technology 20:90-94. (Department of Agronomy, University of Florida, Gainesville, FL 32611). Mowing prior to herbicide treatment with hexazinone does not improve control of giant smutgrass. A rate of 1.0 pound $\cdot$ acre $^{-1}$ of hexazinone is recommended.

Recovery and germinability of native seed fed to cattle. M. K. Whitacre and C. A. Call. 2006. Western North
American Naturalist 66:121-128. (C. Call, Department of Forest, Range, and Wildlife Science, Utah State University, Logan, UT 84322). Globemallow and bottlebrush squirreltail seeds may be suited to dispersal on rangeland by feeding them to livestock, but seeds of Wyoming big sagebrush are not.

Revegetation equipment catalog. H. Wiedemann, N. Shaw, M. Pellant, and S. Monsen. 2005. (http://revegcatalog.tamu.edu). This web-based publication was compiled by the Rangeland Technology and Equipment Council in partnership with the US Forest Service Rocky Mountain Research Station and the BLM Great Basin Restoration Initiative. Provides descriptions, applications, and photographs of equipment designed for rangeland vegetation manipulation, wildlife habitat improvement, and disturbedland rehabilitation. Vendor contact information is included.

Tall ironweed (Vernonia altissima Nutt.) control in pastures with fall-applied herbicides. M. W. Marshall, J. D. Green, D. C. Ditsch, and J. W. Turner. 2006. Weed Technology 20:52-57. (J. Green, Department of Agronomy, University of Kentucky, Lexington, KY 40546). Midsummer mowing followed by fall application of triclopyr effectively removed tall ironweed from grass pastures.

\section{Soils}

Spatial variability of soil chemical properties of a prairie-forest transition in Louisiana. A. Bekele and W. H. Hudnall. 2006. Plant and Soil 280:7-21. (Environmental Science Research Center, St. Francis Xavier University, PO Box 5000, Antigonish, NS B2G 2W5, Canada). Soil pH can be used to objectively delimit the prairie-forest boundary where eastern red cedar trees are encroaching into grasslands. Prairie soils are basic $(\mathrm{pH}>7.0)$ and forest soils are acidic $(\mathrm{pH}<7.0)$.

Jeff Mosley is Professor of Range Science and Extension Range Management Specialist, Department of Animal and Range Sciences, Montana State University, Bozeman, MT 59717. 


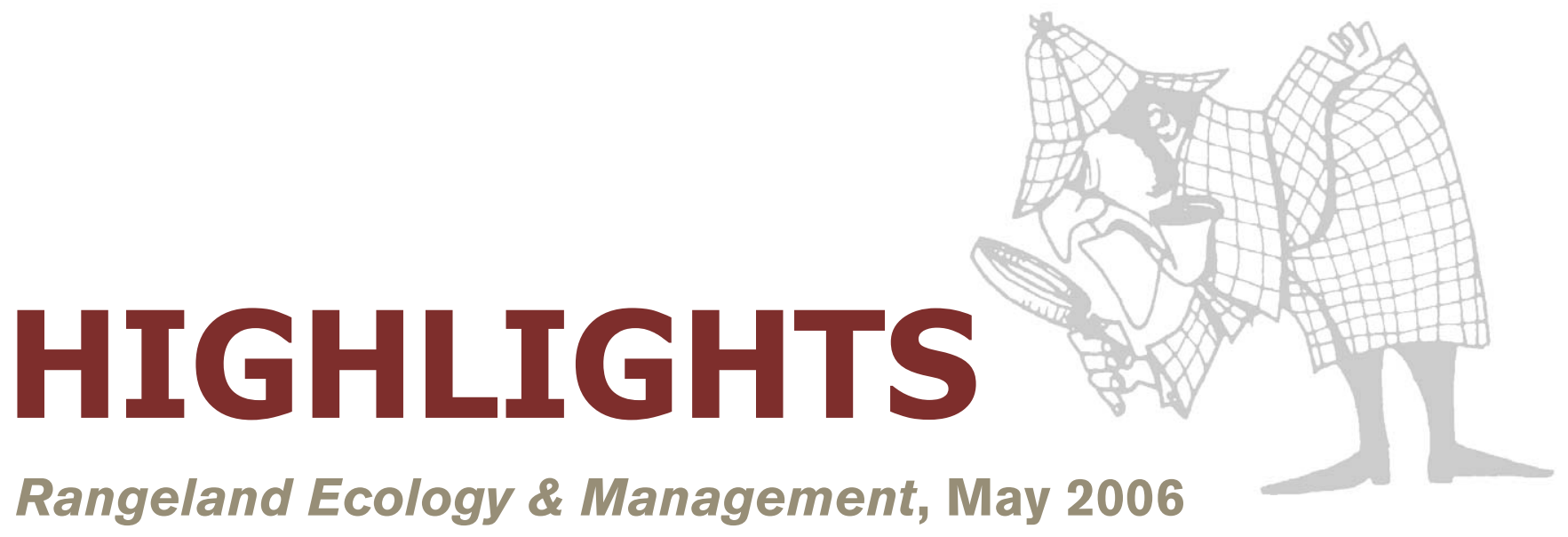

\section{A Unified Framework for Assessment and Application of Ecological Thresholds}

D. D. Briske, S. D. Fuhlendorf, and F. E. Smeins

This synthesis is intended to promote development of a unified framework for threshold assessment that is able to link ecological theory and processes with management knowledge and application. Specific objectives address threshold mechanisms, threshold components, threshold categories and trajectories, and an operational threshold definition. Operational thresholds are based on a probabilistic interpretation of 1) the occurrence of triggers that initiate thresholds, 2) the trajectory of postthreshold states, and 3) threshold reversibility. A greater understanding of thresholds is necessary because they have become a focal point of state-andtransition models and their occurrence has critical consequences for land management.

\section{Fire Rehabilitation Using Native and Introduced Species: A Landscape Trial}

Tyler W. Thompson, Bruce A. Roundy, E. Durant McArthur, Brad D. Jessop, Blair Waldron, and James N. Davis

A large-scale fire rehabilitation was initiated comparing a predominately introduced-species seed mix (BLM), a mix of native and introduced seeds (ARS), and 2 native seed mixes (high and low diversity). On drill seeded plots, the native high-diversity mix had the highest seeded species cover and density. Aerially seeded and chained plots had similar and successful seeded species frequency, cover, and density among all mixes. All seeded plots had lower cover of annual species than unseeded plots, indicating that revegetation is necessary to reduce weed invasion following catastrophic wildfire in big sagebrush communities lacking residual perennial understory vegetation.

\section{Rotational Grazing Effects on Rangeland Vegetation at a Farm Scale \\ Elizabeth J. Jacobo, Adriana M. Rodríguez, Norberto Bartoloni, and Víctor A. Deregibus}

Maximization of livestock production and economic profits requires maintaining high stocking rates, but excessive grazing often leads to land degradation and loss of biodiversity. We evaluated the adequacy of rotational grazing at high stocking rates to improve Flooding Pampa rangeland condition, compared to continuous grazing. Cover of higher-forage-value species (legumes, C3 grasses, and hydrophytic grasses) increased, whereas cover of lower-forage-value species (forbs, C4 prostrate grasses) decreased, under rotational grazing. These changes indicate an improvement in rangeland condition and in carrying capacity, therefore productivity and sustainability may be compatible with applying rotational grazing at high stocking rates.

\section{Sideoats Grama Growth Responses to Seasonal Fires and Clipping \\ R. James Ansley, Michael J. Castellano, and William E. Pinchak}

There is increased interest in the use of summer fires to limit woody plant encroachment on southern prairie grasslands in the United States, but collateral effects of summer fires on grasses are poorly understood. We quantified effects of repeated winter fires, repeated summer fires, simulated grazing (clipping), and their interaction on yields of the $\mathrm{C} 4$ midgrass, sideoats grama (Bouteloua curtipendula). The results suggest that sideoats grama is tolerant of summer fires but full recovery requires at least 3 years. In the long term, summer fire in combination with clipping may stimulate sideoats grama production compared to winter fire plus clipping or clipping alone.

\section{Nutritive Quality of Big Bluestem (Andropogon gerardii) and Eastern Gamagrass (Tripsacum dactyloides) Exposed to Tropospheric Ozone}

John S. Lewis, Stephen S. Ditchkoff, John C. Lin, Russell B. Muntifering, and Arthur H. Chappelka

Tropospheric ozone $\left(\mathrm{O}_{3}\right)$ is a phytotoxic air pollutant widespread in industrialized nations of the world and can be transported from metropolitan to rural areas. The effects of 
tropospheric $\mathrm{O}_{3}$ on 2 warm-season grasses, eastern gamagrass (Tripsacum dactyloides L.) and big bluestem (Andropogon gerardii Vitman), were examined during June-September of 2003. Big bluestem exhibited little response to $\mathrm{O}_{3}$ exposure. For eastern gamagrass, we generally found decreased nutritive quality with increasing $\mathrm{O}_{3}$ exposure. Range managers can use species-specific information regarding $\mathrm{O}_{3}$ sensitivity to make decisions about mechanical harvesting and grazing regimes of these forages growing in areas exposed to elevated $\mathrm{O}_{3}$ concentrations.

\section{Stockpiled Forage Kochia to Maintain Beef Cows During Winter}

\section{Blair L. Waldron, Dale R. ZoBell, Kenneth C. Olson,} Kevin B. Jensen, and Donald L. Snyder

Extending grazing into the winter, as opposed to feeding harvested forages, can increase the sustainability of ranching in the western United States. Changes in cow body weight, body condition score, and ultrasound backfat were compared for late-gestation cows grazing forage kochia-crested wheatgrass pastures vs those fed alfalfa hay in a drylot. Cows grazing forage kochia-grass gained body weight, increased in body condition, and maintained backfat thickness, finishing well within the range considered optimum for onset of calving and return to estrus. Forage kochia can be used to extend grazing into the fall and winter, thereby improving the profitability of beef production.

\section{Efficacy of Copper Supplementation in the Prevention of Molybdenosis in Cattle}

Walter Majak, Daniel Steinke, Tim Lysyk, Keith Ogilvie, and Jason McGillivray

Cattle grazing on reclaimed mine tailings rich in molybdenum (Mo) has been avoided in the past because of the threat of molybdenosis. To show that cattle grazing is a viable option, a copper sulphate supplement was provided that ensured adequate intake of copper to compete with the elevated levels of Mo in the forage. The supplement significantly decreased clinical signs of molybdenosis and permitted grazing on reclaimed mine tailings with acceptable gains. Other regions of North America that show elevated levels of Mo in soils and forages might be considered for cattle grazing if a copper sulphate supplement was provided.

\section{In Vitro Ruminal Fermentation Using Inoculum From Chamois and Cattle}

\section{A. Dalmau, A. Ferret, X. Manteca, and S. Calsamiglia}

Few data exist examining the differences in the fermentative activity of the microbial populations between chamois and cattle. A dual-flow continuous culture was used to compare the digestibility of the diet, ruminal fermentation profile, and nitrogen metabolism of rumen microbial populations obtained from chamois and cattle inocula. Both microbial populations had a similar digestion capacity, producing the same amounts of volatile fatty acids, but with a different fermentation profile, and reduced microbial protein synthesis in the case of chamois inocula. The in vitro system used is a useful tool for studying the ruminal activity in wild species.

\section{Predicting Diet Quality of White-Tailed Deer via NIRS Fecal Profiling}

Scott E. Showers, Douglas R. Tolleson, Jerry W. Stuth, James C. Kroll, and Ben H. Koerth

Determination of diet quality in free-ranging wildlife is problematic; near infrared spectroscopy (NIRS) of feces is a noninvasive means to accomplish this task. Fecal NIRS predictive equations for crude protein and digestible organic matter were developed utilizing 88 unique diets fed to whitetailed deer (Odocoileus virginianus). Cross validation, independent validation with pen-fed animals, and comparison to Normalized Difference Vegetation Index data in a wild herd indicate fecal NIRS can be used to predict diet quality in a free-ranging population. Georeferenced fecal NIRS predictions, collected at regular intervals in concert with forage availability, could provide baseline habitat and resource quality assessments for white-tailed deer.

\section{Fall and Winter Habitat Use by Scaled Quail in Southeastern Arizona}

Kirby D. Bristow and Richard A. Ockenfels

Scaled quail (Callipepla squamata pallida Vigors) are closely associated with semidesert grasslands of the southwestern United States, and populations have declined by as much as $50 \%$ since 1960 . Scaled quail used areas with grass canopy cover $\geq 26 \%$, tree canopy cover $\leq 10 \%$, and higher grassspecies richness than randomly available. Land management practices that reduce grass species richness and cover, and increase tree cover may reduce scaled quail habitat quality and availability in southeastern Arizona. We recommend that semidesert grassland habitats contain a maximum tree canopy of $<6 \%$ and grass canopy cover of $>25 \%$ at the $20-\mathrm{cm}$ height to provide optimum cover availability.

\section{Changes in Soil Properties and Enzymatic Activities Following Manure Applications to a Rangeland}

Jourdan M. Bell, Clay A. Robinson, and Robert C. Schwartz

Manure applications to rangelands can increase the land base available for nutrient assimilation but may also influence nutrient recycling in soils. We investigated the effects of cattle manure applications and grazing on dehydrogenase and alkaline phosphatase activities and soil organic carbon, nitrogen, and phosphorus in a short-grass, native rangeland. Soil 
$\mathrm{P}$ extractability as a proportion of total $\mathrm{P}$ applied were similar for manure and $\mathrm{KH}_{2} \mathrm{PO}_{4}$ amendments, possibly as a result of greater alkaline phosphatase activities following manure applications that led to enhanced $\mathrm{P}$ mineralization. Therefore, when determining application rates, total manure $\mathrm{P}$ should be considered bioavailable.

\section{Soil Attributes in a Sierra Nevada Riparian Meadow as Influenced by Grazing}

\section{Robert R. Blank, Tony Svejcar, and Gregg Riegel}

Data on the effect of livestock grazing on soil nutrient availability is virtually nonexistent. We measured the effect of livestock grazing on soil-solution chemistry, spatially and by soil depth, across a Sierra Nevada (California) riparian meadow for 4 years. Overall, the grazed treatment had greater concentrations of sodium, calcium, magnesium, and nitrate and less potassium and ammonium in the soil solution than did the livestock exclusion treatment, but only near the upland forest-riparian boundary. Management goals to sustain highelevation meadows should emphasize maintenance of high root-length densities to sequester soil nutrients.

\section{Grass Repellency to the Red Imported Fire Ant}

\section{Troy Sternberg, Gad Perry, and Carlton Britton}

The invasive red imported fire ant continues to cause extensive ecological and economic damage as it spreads in North America and elsewhere. We examined the ability of WW-B.Dahl, an Old World bluestem increasingly used in pastures, to limit or reduce ant infestations. Pastures planted with B.Dahl had about one-third the fire ant mounds found in adjacent pastures, a statistically significant difference. A reduction in fire ant mounds can improve the efficiency of haying operations and reduce wildlife impacts, suggesting broad uses for WW-B.Dahl in ant-infested areas.

\section{An Advanced, Low-Cost, GPS-Based Animal Tracking System \\ Patrick E. Clark, Douglas E. Johnson, Mark A. Kniep, Phillip Jermann, Brad Huttash, Andrew Wood, Michael Johnson, Craig McGillivan, and Kevin Titus}

Commercially available animal tracking systems do not meet the needs of ecological researchers and natural resource managers. The Clark GPS Animal Tracking System (Clark ATS) was developed to provide large data-storage capacity, remote data downloading, and continuous real-time data access to researchers and managers intensively tracking animal behavior over long time periods. The Clark ATS costs less than $\$ 1,000$ per unit, stores up to $8 \mathrm{~GB}$ of data, uses spread-spectrum radio, and requires little power $(<100 \mathrm{~mW})$. Technological advances incorporated into the Clark ATS enable users to accurately examine animal distribution and activity responses to acute, short-term disturbances relative to longer-term behavioral patterns.

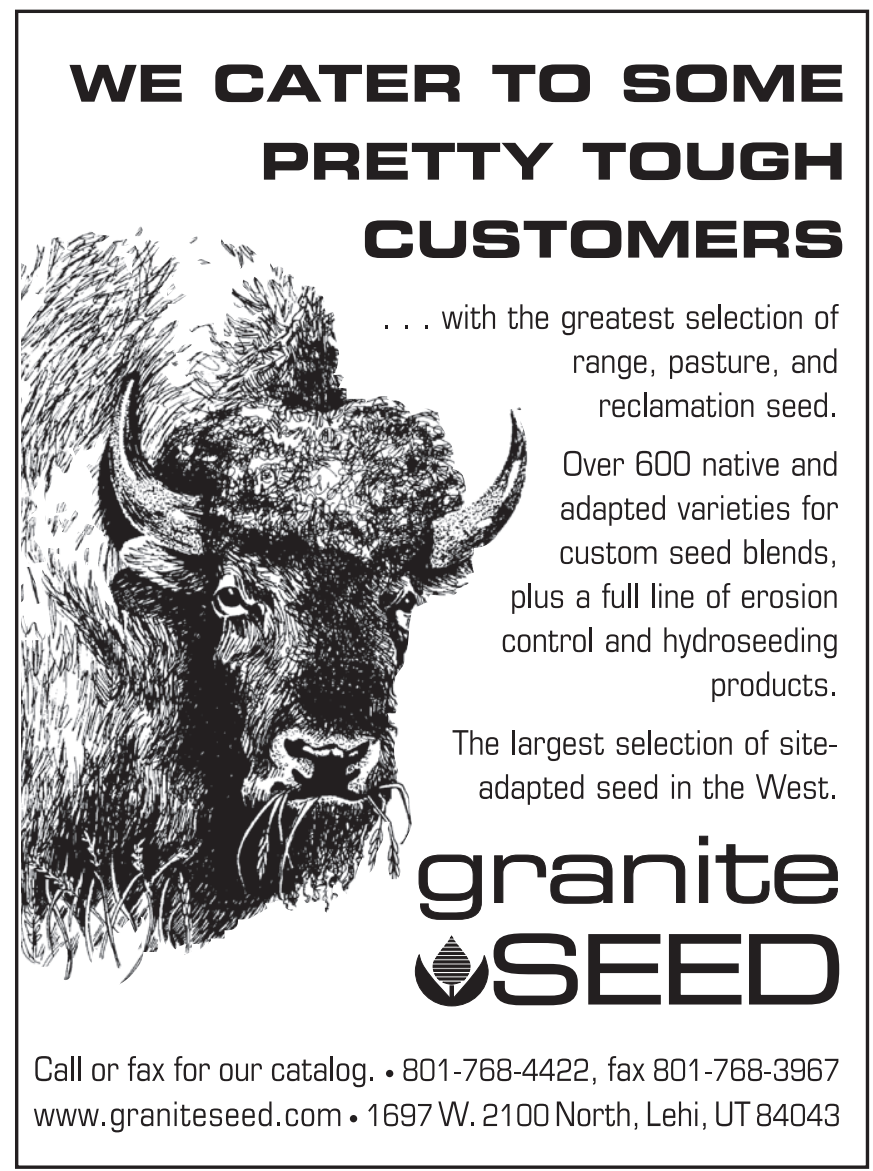




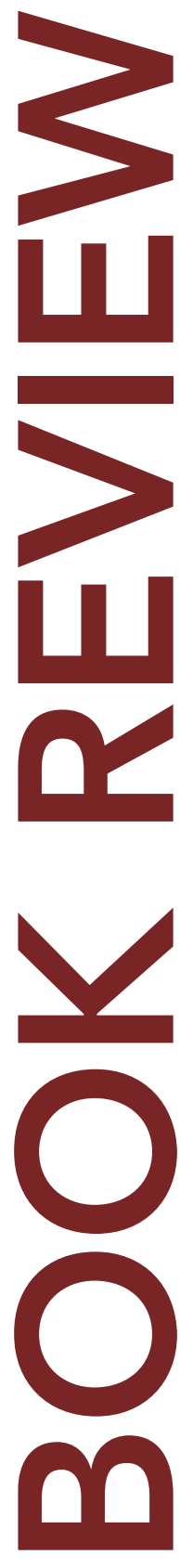

The Badge With a Tree. By Stan Tixier. 2005. Western Heritage Company, Loveland, CO. 201 p. US\$14.95 paper. ISBN 1-887200-13-4.

In Stan Tixier's previous novel, Green Underwear, he bases his stories on true-life experiences. The characters are fictitious, except for one that is based on a real-life Forest Service ranger. The Badge With a Tree is designed similarly. Some readers will know which character is real, but others will have to figure out or guess which one. Green Underwear tells a story about Lawrence G. Weaver III (Larry) and his adventures on the Elk Creek District of the Rio Verde National Forest. The Badge With a Tree is a prequel to Green Underwear, which was reviewed in the August 2002 issue of Rangelands. This prequel tells a story about district ranger Lawrence E. Weaver Jr. (Lew); his wife, Grace; and their teenage sons, Larry and Jim.

Set in an earlier time, this novel tells how things used to be on several typical ranger districts on western National Forests, including a National Grassland district. It describes the daily activities of a forest ranger and his staff and begins with an airplane crash.

Ranger Lew Weaver was in the copilot seat looking for forest fire starts from a recent storm. Pilot Carol James heard a change in the sound of the engine of her Cessna 180. Before a course change could be made taking them back to town, the engine noise increased and there was a sharp BANG. "We might have thrown a connecting rod and if so a piston has probably been blown down into the crank case," Carol said to Lew. Seeing that a smooth landing was out of the question, she told her copilot to "hang on we'll be touching down, soon." The touchdown was surprisingly smooth, at 45 or $50 \mathrm{mph}$ before the plane rolled and bounced over the grass. Lew was able to walk away, but Carol was unconscious. Lew pulled Carol away from the wreckage before it burst into flames. They were rescued by a helicopter fire-fighting crew. Carol was taken to the hospital with a broken leg and Lew headed back to his office before going home.

Recovering from the plane crash, Ranger Lew set out the next day to check on a control compliance for a timber sale, then to meet with a lumber company officer. He meets with the foreman of the $Z$ Bar Ranch, where the owner has a grazing permit for 750 head of cattle. The owner is a poor manager and has failed to meet Forest Service standards of his leasing agreement. This leads to a roundup to determine how many cattle are actually on the allotment.

The ranger's stories include law enforcement challenges, catching tree thieves, and spotting forest fires. Lew's 2 sons enjoy listening to their dad tell about his days in the Navy during World War II in the Pacific. They especially enjoyed Lew's story of a grizzly bear attack. Through the ranger's stories the reader will learn about the US Forest Service and its mission and challenges.

Author Stan Tixier is retired and lives in Eden, Utah, where he and his wife, Jan, raise and train foxtrotting horses. Stan is also a well-known cowboy poet. He is an ex-ranger, forest supervisor, and regional forester. Always a strong supporter of the Society for Range Management, he served as Society President in 1991.

Past President and Society member William D. Hurst, retired Regional Forester, Southwestern Region, states in the beginning of The Badge With a Tree, "If you are interested in the work and responsibilities of a district forest ranger in the on-the-ground management of the National Forests, read this book. The situations described and the problems confronted, although fictional, are encountered regularly by this special guardian of the beautiful National Forests, the district forest ranger." The forest ranger is a special public servant.

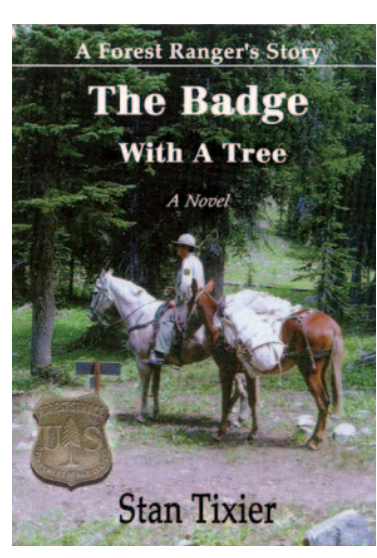

Jan Wiedemann, Texas Section Society for Range Management, College Station, TX. 
Prairie Gothic: The Story of a West Texas Family. By John R. Erickson. 2005. University of North Texas Press. 208 p. US\$16.95 softcover. ISBN 1-57441-203-5.

I met John Erickson at the Texas Book Festival in October 2004 in Austin. That was the same month that Rangelands featured my review of Erickson's book The Modern Cowboy. While attending the 2005 Texas Book Festival I learned about his latest book, Prairie Gothic. I then asked him if I could read and write a review for Rangelands. He readily agreed and I can say I thoroughly enjoyed reading stories of his West Texas family.

Erickson begins by saying this book was difficult to get started. He tried many times to write the story of his West Texas family, even trying to make it into a novel. He put his research notes away in a drawer and forgot about them for many years, even decades. When he went back to the material in May of 2004 he said his motivation was simple, "I needed an escape from the boredom of sitting in my writing office every morning, for 5 hours. Anything would do." Out of "anything would do" Erickson produced the story of his mother's family.

The author's mother, Anna Beth Curry Erickson, loved language, told wonderful stories, and believed that passing those stores to her son was more important than doing other things for herself. She told stories about her family in West Texas. Some involved kinfolk: the Sherman great-uncles, Roy, Burt, and Roger; their sisters, Aunt Olive and Grandmother Curry; Great-grandmother Perlina Sherman; and Buck Curry, the author's grandfather. Some stories involved people who were more distant, but part of the family history: the Quaker Underhills; Martha Sherman, who died under a Comanche scalping knife; Tom Ross, the notorious outlaw and killer; and the author's great-grandfather, Joe Sherman.

One branch of relatives, the Underhills and the Singers, helped establish the first community on the South Plains, the Quaker Colony of Estacado. They had joined a group of Quakers from Iowa, then boarded a train in Kansas City, where each family member was allowed 200 pounds of baggage, and rode to Fort Worth, where they saw buffalo bones beside the railroad tracks. They transferred to wagons that took them to the last outpost of civilization at Fort Griffin. Citizenship in Fort Gibson was made up of a small company of soldiers, along with some ranchers and buffalo hunters. But most of the citizens were the scum of the earth—desperados, fugitives from justice. There were saloons and dance halls, gambling and drinking, and all kinds of crime. There was a small tribe of Tonkawa Indians camped near the town. By the time the family reached the Llano Estacado, they may have had second thoughts and wondered if they should turn around and go back. The families lived in tents until houses were built. Once they were established, Harvey Underhill built and operated a hotel. These Quakers were industrious, law abiding, kind hearted, and honest people. They established schools and helped build a community in the wilderness.

Another branch of Erickson's family arrived in Texas in 1858 and settled in Parker County west of Weatherford. Erickson's mother, Anna Beth, told many stories about her grandfather Joe Sherman. When Sherman was a boy his mother, Martha, was killed by Indians. Always curious about this family story, Erickson wondered about the details: such as when, where, why, and what kind of Indians. In the summer of 1966, while visiting his Grandmother Curry, Erickson found J. Evetts Haley's biography of Charles Goodnight. In that book there is a wonderful passage about the fate of Martha Sherman. This was the story Erickson's mother had told him years before. Now he had a place and a time: Parker or Palo Pinto County, Texas, in November of 1860. After searching the Texas Archives in Austin and poring over newspapers, files of letters, books on frontier history, and microfilm records, the author realized that the death of Martha Sherman was a major news event on the Texas frontier in the winter of 1860-1861.

The theme that runs throughout the book is that of 4 generations' efforts to nurture the values of civilized people. It is a story of pioneer men and women and their struggles to keep their families together. Erickson writes about the history of his family and the region. In his foreword, author Elmer Kelton writes, "Erickson has given us a vivid and well-rounded picture of several generations in a pioneer family. He offers sharp and clean images, and his prose often has a poetic quality."

John Erickson, a fifth-generation Texan, was born and raised in the Texas Panhandle town of Perryton. He and his wife, Kristine, run their own ranch and commercial cattle operation. In 1982, Erickson created the Hank the Cowdog series, seeing sales of more than 6 million copies.

A story rich in family history, Prairie Gothic is enjoyable reading.

Jan Wiedemann, Texas Section Society for Range Management, College Station, TX.
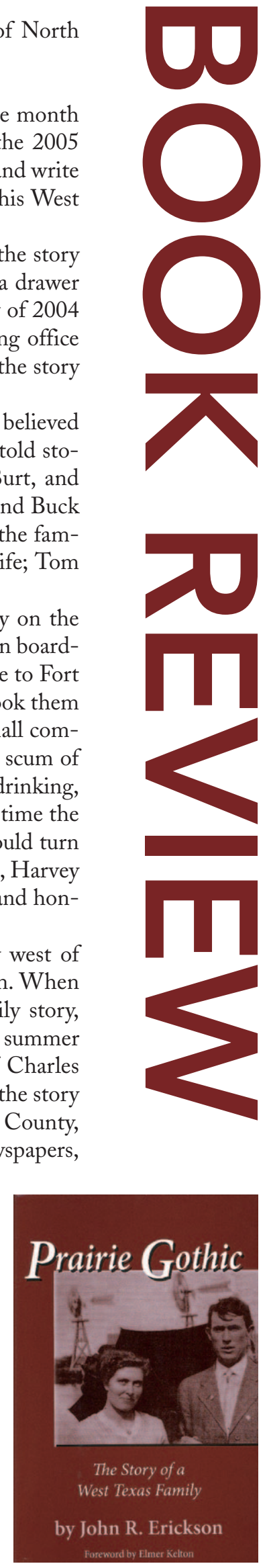